UNIVERSIDADE DE SÃO PAULO

FACULDADE DE FILOSOFIA, CIÊNCIAS E LETRAS DE RIBEIRÃO PRETO

DEPARTAMENTO DE PSICOLOGIA

PROGRAMA DE PÓS-GRADUAÇÃO EM PSICOLOGIA

\title{
MARCELLA CASSIANO
}

Investigação de um programa Cognitivo-Comportamental de orientação de pais no contexto de promoção de saúde

Ribeirão Preto 
MARCELLA CASSIANO

Investigação de um programa Cognitivo-Comportamental de orientação de pais no contexto de promoção de saúde

Dissertação apresentada à Faculdade de Filosofia, Ciências e Letras de Ribeirão Preto/USP, como parte dos requisitos para obtenção do grau de Mestre em Ciências.

Área de concentração: Psicologia

Orientadora: Prof. ${ }^{\text {a }}$ Dr. ${ }^{\text {a }}$ Carmem Beatriz Neufeld

Ribeirão Preto 
Autorizo a reprodução e divulgação total ou parcial deste trabalho, por qualquer meio convencional ou eletrônico, para fins de estudo e pesquisa, desde que citada a fonte.

Cassiano, Marcella

Investigação de um programa Cognitivo-Comportamental de orientação de pais no contexto de promoção de saúde. Ribeirão Preto, 2014.

123 p. : il. ; $30 \mathrm{~cm}$

Dissertação de Mestrado, apresentada à Faculdade de Filosofia, Ciências e Letras de Ribeirão Preto/USP. Área de concentração: Psicologia.

Orientadora: Neufeld, Carmem Beatriz.

1. Abordagem Cognitivo-Comportamental. 2. Grupos. 3. Orientação de Pais. 4. Promoção de Saúde. 
Nome: Cassiano, Marcella

Título: Investigação de um programa Cognitivo-Comportamental de orientação de pais no contexto de promoção de saúde

Dissertação apresentada à Faculdade de Filosofia, Ciências e Letras de Ribeirão Preto/USP, como parte dos requisitos para obtenção do grau de Mestre em Ciências.

Aprovado em:

Banca Examinadora:

Prof. Dr.

Insitituição: Assinatura:

Prof. Dr.

Insitituição: Assinatura:

Prof. Dr.

Insitituição: Assinatura: 
Aos meus pais e ao Fábio, por me ensinarem no cotidiano a valorizar tanto o cuidado com a família. 


\section{AGRADECIMENTOS}

Agradeço aos meus pais Rose e Ocimar, por, mesmo sem terem recebido nenhum tipo de Orientação quando ficaram grávidos, terem feito tudo por mim. Agradeço por me amarem, me apoiarem e por acertarem tanto. Por estarem comigo em cada pequena etapa e, nessas muito grandes também. Por todas as vezes que me mantiveram firme quando eu reclamei ou desanimei e por serem, sempre, meu maior porto seguro.

Ao meu amor, noivo durante o processo de mestrado e quase marido agora. Por estar comigo, por me emprestar sua lógica prática de engenheiro, toda que vez que eu, psicóloga prolixa, precisei. Por me dar colo, por dizer que tudo ia ficar bem... e, em algumas vezes, concordar comigo que nem tudo ficaria tão bem assim e me dar recursos para caminhar sempre

Agradeço a todos os pais, mães, madrinhas, avós e tias que participaram desse estudo. Foi um presente conhecer um pouco mais sobre suas famílias e, saímos com a gostosa sensação de ter contribuído um pouquinho para que todas essas bonitas relações com seus pequenos se fortaleçam.

À Bia, minha orientadora e professora durante os seis anos de participação do Lapicc, desde que ele era conhecido apenas como "a sala da Bia", quando comecei a estagiar. Foi você que me apresentou á TCC e guiou meus primeiros passos de estágio, que me acolheu quando os desafios apareceram e que me ajudou a seguir em frente. Obrigada também por embarcar comigo nessa jornada de intervenções com pais, que sempre foi minha paixão e, principalmente, muito obrigada por acreditar em mim.

Às minhas amigas: Mara, Isa, Luiza, às minhas Vanessas, Náira e Pri, pela amizade e companheirismo, na pesquisa e na minha vida.

Agradeço também à Pati, Gabi, Duda, Kátia, Carol e ao Saulo, pela parceria no LaPICC e ao André, minha dupla de estágios, provas de desempate de seleção, grupo de estudos e aulas de especialização.

Ao Diogo, que me ajudou de longe... lá de Porto Alegre, com instrumentos para o PROPAIS e para outros estudos do Lab. Além de me dar dicas preciosas no decorrer do trabalho. Agradeço também, novamente, por ser tão educado, carinhoso e solícito em cada um dos contatos por email. Foi ótimo traçar o início de uma parceria com você e com o seu lindo CEP-Rua da UFRGS.

Obrigada pra cada um dos estagiários e observadores que construiram um pouquinho do PROPAIS II e ajudou ele a ganhar vida: Thalita, Katherine, Sarah, Saulo, César, Ju, Isa e Fernanda. Vocês fizeram um lindo trabalho!

Agradeço também a cada um dos membros do LaPICC, antigos e atuais, que, nesses seis anos, fizeram minha vida profissional ser mais rica e minha vida pessoal mais feliz. 
À Zezé e à Rosana, por terem aberto as portas da instituição pra gente e pelo bonito trabalho que fazem com as crianças e a comunidade. À irmã Eulália, à Luiza e à Jaque, pelo igualmente belo trabalho com os pequeninhos e suas famílias e por terem me recebido tão bem!

Meu muito, muito obrigada mesmo, aos meus três anjinhos: da matemática, do português e das línguas: Obrigada Elisângela pelo auxílio e supervisão estatística, obrigada Bia Telles por rever meu texto e ser tão carinhosa comigo e, obrigada querido Lucas por limpar as ferrugens do meu inglês.

Obrigada de coração a professora Edna e a ao professor Maycoln pelas valiosas contribuições na minha banca de qualificação e por aceitarem estar comigo novamente, Ouvir vocês dois me inspira... e muito!

Agradeço também aos meus outros grandes mestres, ao longo de todo o percurso de estudo, que marcaram minha vida cada um de um jeito e que carrego no coração pra sempre: D. Lilian, D. Cris, Marcos, Maurício, Paulinho, Furlan, Regina e Kátia. Muito de mim é de vocês.

Muito obrigada a todos, que tiveram paciência comigo, e direta ou indiretamente, sofreram os efeitos das minhas 'loucuras' por uma construção de mestrado e o planejamento conjunto de um casamento.

Por fim, agradeço a Deus por ter me dado tudo isso e todas essas pessoas e as muito mais que não caberiam aqui. Por guiar meus passos e intenções e por me abençoar sempre. 


\section{RESUMO}

Cassiano, M. (2014). Investigação de um programa Cognitivo-Comportamental de orientação de pais no contexto de promoção de saúde. Qualificação de Mestrado, Faculdade de Filosofia, Ciências e Letras de Ribeirão Preto, Universidade de São Paulo, Ribeirão Preto - SP

A família é um componente fundamental para o desenvolvimento e socialização infantil. Práticas educativas parentais adequadas e consistentes influenciam positivamente o repertório comportamental e emocional da criança, além do relacionamento intrafamiliar. No entanto, apesar da necessidade de orientar pais ser amplamente mencionada na literatura, há poucas intervenções estruturadas descritas que visem esse objetivo, sobretudo anteriores ao surgimento de queixas clínicas infantis. Mais escassas ainda são as modalidades de orientação de pais que incorporam aspectos cognitivos e emocionais. Este estudo visa contribuir com a aquisição e aprimoramento de práticas educativas parentais adequadas e investir em uma melhor interação familiar, ao propor e investigar o PROPAIS II, um programa de orientação de pais Cognitivo-Comportamental de duração breve. Este se volta para pais de crianças em idade escolar e finalização da educação infantil e enquadra-se no contexto de promoção de saúde, sendo realizada em instituições não governamentais de educação e fortalecimento de vínculos. Participaram do estudo 25 pais ou cuidadores de crianças, de duas instituições não governamentais de grande porte do Interior de São Paulo. Os instrumentos utilizados foram: Child Behavior Checklist (CBCL 6/18 anos), Escalas de Qualidade na Interação Familiar (EQIF-versão pais) e Critério de Classificação Econômica Brasil (CCEB). Os participantes foram submetidos às seis sessões do Programa e duas sessões de testagem, uma anterior e uma posterior ao grupo interventivo. O Programa foi aplicado em grupos, com média de cinco participantes cada, sendo oferecido em seis grupos independentes. Para verificar a efetividade do Programa para os participantes foram realizadas análises quantitativa dos dados comparando os escores pré e pós-intervenção e análise qualitativas dos relatos dos pais nas sessões e na avaliação final, coletadas por registro das falas durante as sessões. O intervalo de confiança adotado para o estudo foi de $95 \%$. Os resultados indicam que os participantes obtiveram melhoras significativas na Interação Familiar, adotando práticas educativas mais positivas e adequadas, ganhando também maior consciência acerca de seus sentimentos, comportamentos e emoções. Sugerem também ampliação da compreensão do comportamento de seus filhos e dos próprios, relacionados ao educar, sinalizando a importância da inserção do Modelo Cognitivo na orientação de pais. As queixas comportamentais infantis, na percepção dos pais, mostraram modificações quanto a problemas externalizantes, sobretudo agressividade. Os resultados obtidos após as seis sessões apontam para a importância de se investir no treinamento para aquisição de melhores práticas educativas parentais e interação familiar mais saudável. O estudo sinalizou também dificuldades na adesão dos pais para formação dos grupos, justificando novos investimentos para compreensão de fatores relacionados à baixa adesão e para que abarque mais participantes.

Palavras-chave: Abordagem Cognitivo-Comportamental. Grupo. Orientação de pais. Promoção de Saúde. 


\begin{abstract}
Cassiano, M. (2014). Investigation of a Cognitive-Behavioral parents guiding program into health promotion's context. Master degree's qualification, Philosophy, Science and Litterature's college of Ribeirão Preto, São Paulo University, Ribeirão Preto-SP.
\end{abstract}

Family is a key to child's development and socialization. Appropriate and consistent parenting practices positively influence the behavioral and emotional repertoire of the child and the intrafamily relationship. However, despite the need to counsel parents be widely reported in the literature, structured interventions aimed at this goal are scarcely represented in the literature, especially prior to the emergence of children's clinical complaints. Rarer still are the modalities of parents' guiding incorporating cognitive and emotional aspects. This study aims to contribute to the acquisition and improvement of appropriate parenting practices and invest in a better family interaction, while proposing to investigate the PROPAIS II, a brief Cognitive-Behavioral program of parents' guiding. This program aims to parents of schoolage children and completion of early childhood education and fits in the context of health promotion, being performed in non-governmental educational institutions and strengthening of bonds. Study participants were 25 parents or caregivers of children, two non-governmental institutions of Ribeirão Preto - SP. The instruments employed were the Child Behavior Checklist (CBCL 6/18 years), Scales of Quality Family Interaction (EQIF-parent version) and Brazil Economic Classification Criterion (CCEB). Participants underwent six sessions of the program and two testing sessions, one before and one after the interventive group. The program was applied in groups, averaging five participants each, being offered in six independent groups. To assess the effectiveness of the program for participants, quantitative data analysis were employed, comparing pre and post intervention, and qualitative analysis using parental reports at sessions and final assessment scores collected by recording the speeches during the sessions were made. The confidence interval for the study was $95 \%$. The results indicate that participants experienced significant improvements in Family Interaction, adopting more positive and appropriate educational practices, also gaining greater awareness of feelings, behaviors and emotions. Results also suggest expanding the understanding of the behavior of their children and themselves, related to education, signaling the importance of inserting the Cognitive Model in parental guiding. Child behavioral complaints and parents' perception showed changes as externalizing problems, particularly aggression. Results after six sessions point out to the importance of investing in training to acquire better parenting practices and healthy family interaction. The study also signaled difficulties in adhering to parent guiding groups, justifying new investments for understanding factors related to poor adherence and encompassing more participants.

Keywords: Cognitive-Behavioral Therapy. Group. Health Promotion. Parents' Guiding; 


\section{SUMÁRIO}

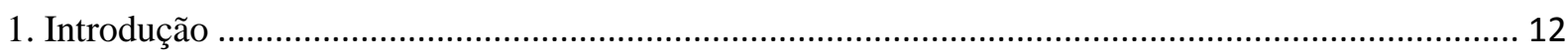

1.1 A família e sua importância na educação dos filhos. ………….............................................. 12

1.2 As estruturas familiares: histórico e contemporaneidade........................................................ 13

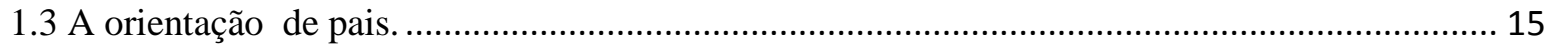

1.3.1. Histórico da orientação de pais. .................................................................................... 18

1.3.2 Alguns componentes comuns da orientação de pais. ...................................................... 19

1.3.4 Programas de orientação de pais e a promoção de saúde .................................................... 21

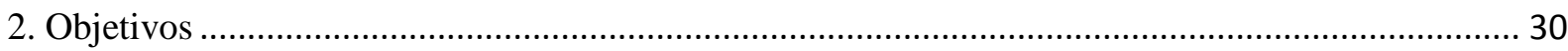

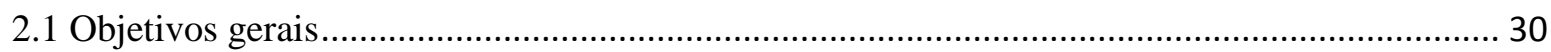

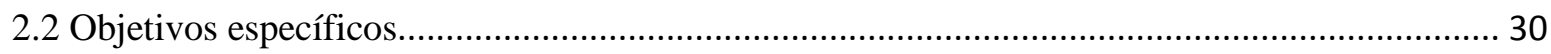

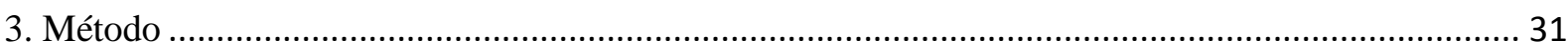

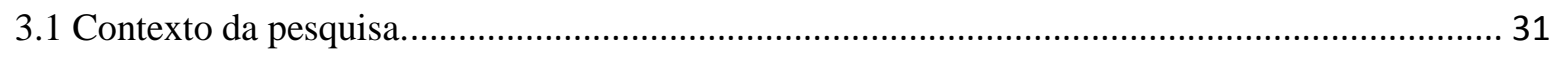

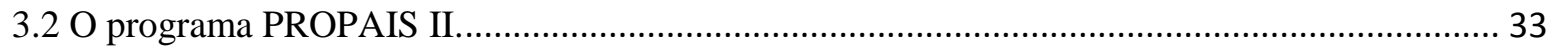

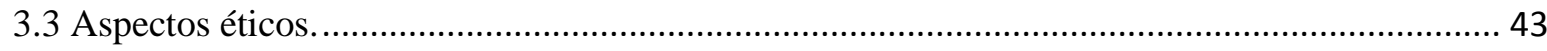

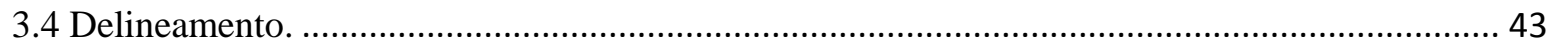

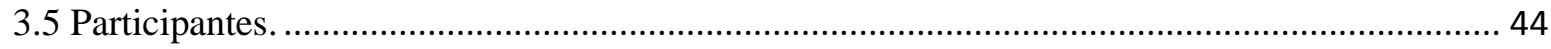

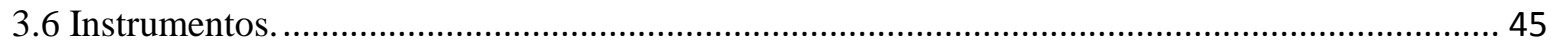

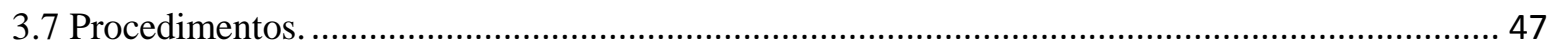

3.7.1 Implementação, coleta e armazenamento dos dados........................................................... 47

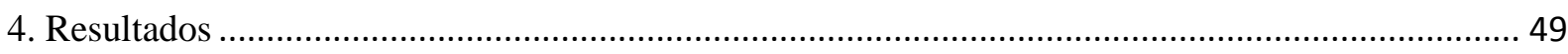

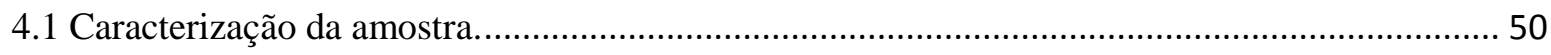

4.1.1 Caracterização do grupo interventivo................................................................................. 51

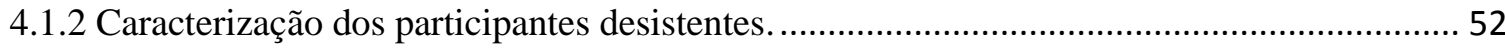

4.2 Práticas educativas parentais e qualidade de interação familiar................................................. 53

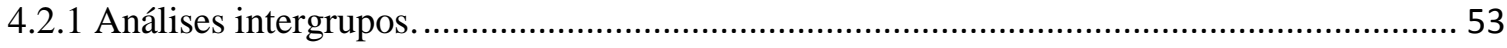

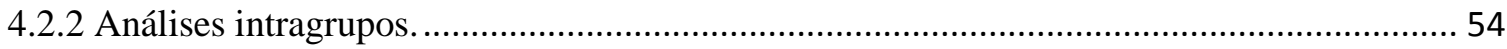

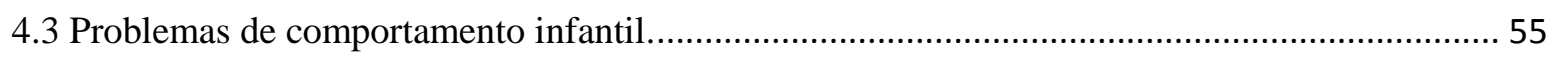

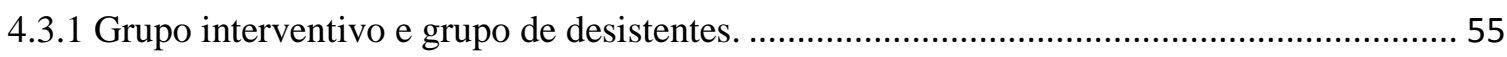

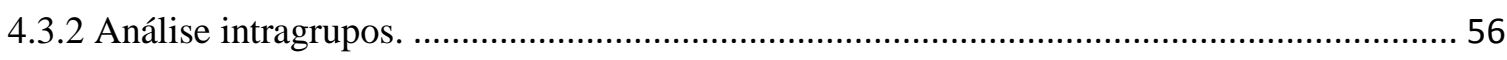

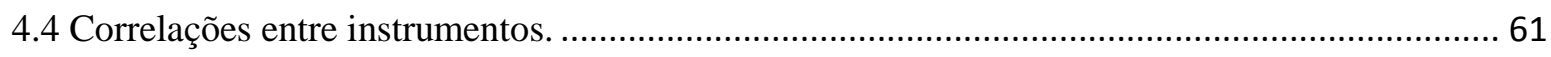

4.5 Análises qualitativas da participação nos grupos. ……………………………......................... 61

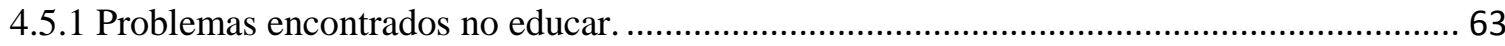




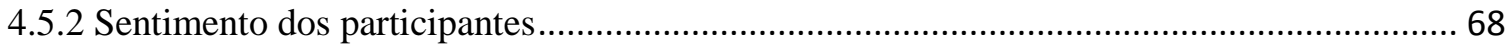

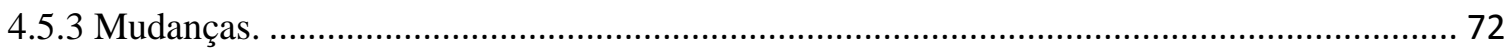

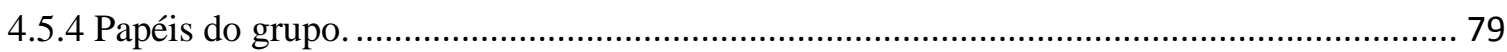

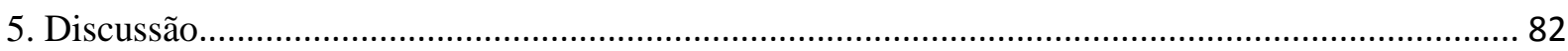

5.1 Caracterização da amostra e do contexto da pesquisa............................................................. 82

5.2 Qualidade na interação familiar e práticas educativas ............................................................... 85

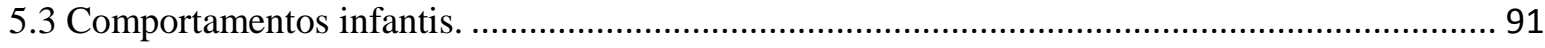

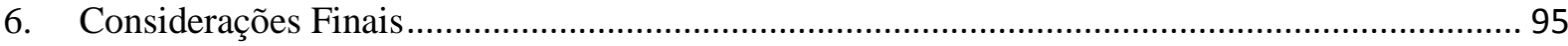

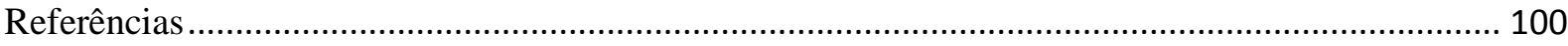

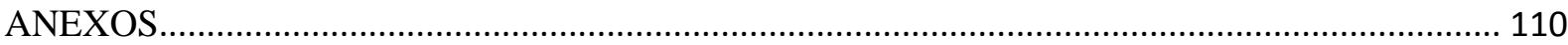




\section{Introdução}

\subsection{A família e sua importância na educação dos filhos.}

A família é meio fundamental de cuidado, socialização, ensino e desenvolvimento infantil. O estudo das relações familiares e sua influência sobre o desenvolvimento humano vem sendo explorado há décadas em diversas áreas do conhecimento como psicologia, educação, antropologia e sociologia. O grande número de estudos sobre o tema reflete o reconhecimento do papel da família como pilar da educação e socialização humana (de Bem \& Wagner, 2006; Minuchin, 1985; Romanelli, 1998). Trata-se também do primeiro foco para o entendimento do comportamento humano (Minuchin, 1985) sendo necessária a compreensão das relações familiares e seus impactos no indivíduo para a realização de intervenções que enfoquem família e as relações intrafamiliares.

Para Weber (2008) a influência da família começa a ser compreendida através do investimento parental de nossos ancestrais, ao se organizarem para garantir a proteção dos bebês humanos, extremamente dependentes, e aumentar suas chances de sobrevivência ao cercá-los de cuidados e proteção. Proteger torna-se então a função inicial principal da família. Função esta, que aos poucos, foi sendo ampliada e diversificada, desempenhando hoje uma complexidade de como educar, modelar, socializar e promover o desenvolvimento infantil emocional e psíquico.

A partir da gestação e nascimento, a criança é inserida em um contexto familiar, que se torna responsável, a princípio totalmente, por seus cuidados físicos, psicológicos e emocionais e pela aprendizagem social, moral e cultural. Assim, a partir do contato e das relações com os pais e demais membros próximos da família, é que a criança começa a estabelecer ligações emocionais, criar esquemas de percepção e cognição, tomar contato com regras de comportamento e linguagem, compreendendo e se inserindo aos poucos na esfera social. Com a experiência familiar, a criança aprende, cria esquemas e modos de significar o que observa, discrimina e testa regras de comportamento, experimenta primeiras punições e recompensas e socializa-se, sendo essa gama de interações que influenciará seus comportamentos e personalidade dali em diante (Sousa \& José Filho, 2008).

A ação socializadora da família permite então que a criança tenha acesso ao patrimônio social e cultural dos adultos, mas não de modo puramente passivo, em que apreende, incorpora e repete, mas sim se apropriando, transformando e incorporando 
elementos a partir das experiências que vivencia. As dinâmicas familiares se tornam então berço de uma construção ativa e transformadora, que impacta as crianças, os pais, os demais meios de socialização e até a própria sociedade em que se insere (Romanelli, 1998).

Um panorama extremamente resumido do papel da família já evidencia sua inquestionável importância para a socialização e desenvolvimento infantil. No entanto, é preciso estar atento acerca das diferenças implícitas no uso do termo genérico 'família', dado que na contemporaneidade há uma imensa diversidade de configurações e estruturas familiares coexistindo (Fonseca, 2005). Para essa mesma autora, intervir e contextualizar são indissociáveis e é inviável ou ao menos descuidado, ter a família como alvo de intervenção sem antes refletir sobre qual família está sendo enfocada e assim, atentar às questões: "Qual sua estrutura?”, “Que valores estão envolvidos no termo 'família' para esses participantes específicos?”, “O que os pais consideram importante?”, “Em que a intervenção pode auxiliar?".

Diante disso, ao se propor um grupo de orientação de pais, é preciso refletir sobre os diversos tipos de família no Brasil que podem vir a recebê-lo, a fim de que a intervenção tenha maiores possibilidades de ser realmente compreendida, apropriada e aplicada por essas famílias participantes. Um breve percurso sobre as influências das estruturas familiares brasileiras na educação dos filhos pode auxiliar na compreensão de alguns modelos que hoje coexistem.

\subsection{As estruturas familiares: histórico e contemporaneidade.}

Os primeiros estudos que traçam a estrutura e perfil familiar brasileiro que influenciaram os modelos atuais datam do período colonial em que predominava a estrutura familiar patriarcal, conforme modelo descrito por Freyre (1933).

Nele, a família era extensa, formada pelo patriarca, sua mulher, filhos e netos, além de filhos ilegítimos, agregados, serviçais e escravos. O controle de tudo era feito pelo patriarca, a divisão de gêneros mostrava-se muito marcada, crianças e mulheres assumiam posturas passivas.

Apesar da família patriarcal ter sido considerada como matriz da família brasileira tradicional, não era o único modelo familiar existente, havendo grande complexidade de interpelações familiares na época (Fonseca, 2005; Samara, 2002). Existiam múltiplas 
configurações familiares, além da aparente predominância patriarcal, refletindo a sempre presente diversidade de interpelações familiares convivendo em uma mesma sociedade.

Faltam relatos nesse período acerca da relação de cuidado e educação das crianças dentro dos modelos de família existentes, não havendo indicações históricas de que fosse reservado às crianças um espaço ou forma de tratamento diferenciado em relação aos adultos da família. Assim, não havia destaque para a infância como uma fase especial do desenvolvimento que necessitasse de atenções específicas, só ficando evidente que a educação e criação dos filhos se pautavam na preparação para assumir as funções dos adultos (Moura \& Araújo, 2004).

Com as mudanças sociais, culturais e econômicas, outro importante modelo de família começou a predominar no Brasil: a família nuclear, classificada por alguns autores, como Parsons e Bales (1955), como o modelo da modernidade. A família nuclear é composta por pai, mãe e filhos. Possui uma estrutura hierarquizada, com maior autoridade paterna, divisão sexual do trabalho bastante marcada e maior vínculo afetivo da mãe com os filhos (Alves, 2009; Romanelli, 2000).

O modelo nuclear surge em um movimento de maior fechamento da família ao externo e maior investimento em privacidade familiar. Essas características parecem ter favorecido a ampliação da consciência da importância dos pais na educação e formação dos filhos, possibilitando maior espaço para se pensar o papel dos pais e suas práticas educativas (Ariès, 1981; Samara, 1986). Apesar de se referir aos pais como conjunto as funções de cuidado, afeto e educação estavam quase totalmente direcionados à mãe.

Na cultura ocidental, a família nuclear é composta geralmente por mãe, pai e filhos e trata-se do modelo predominante na contemporaneidade (Baptista, Cardoso, \& Gomes, 2012), mas não exclui a presença de diferenças nas constituições familiares que coexistam. Para muitos casais o matrimônio legal deixou de ser obrigatório, tornando-se uma escolha e houve um aumento expressivo no número de divórcios e recasamentos nas últimas décadas; as taxas de natalidade caíram e a mulher passou a ter maior participação na manutenção econômica do lar, refletindo em diferentes maneiras de compartilhar papéis no exercício das funções parentais (Fonseca, 2005).

Refletir sobre as diferenças nas dinâmicas e modelos familiares é de grande importância, pois, ao considerar intervir com famílias, os profissionais necessitam compreender e respeitar a realidade de cada família. Sendo incentivados a se despirem de uma visão fechada de estrutura e configuração familiar. Segundo Fonseca (2005), até muito pouco tempo atrás, os pesquisadores interpretavam as mudanças nas estruturas familiares (divórcio, 
recasamento, ausência de filhos por opção, entre outros) como sinal de desestrutura e crise familiar. Faziam isso, possivelmente por estarem profundamente embasados em um único modelo. Essa visão, além de se mostrar empiricamente incorreta, dificulta que intervenções, nela baseadas, possam ser benéficas para as famílias que se estruturam de forma diferente.

Dessa maneira, o percurso traçado acerca das estruturas familiares contemporâneas, mais do que informar, traz consigo a necessidade de levar os pesquisadores e profissionais que estudam e intervém com pais e famílias a estarem atentos e abertos para a diversidade de interpelações familiares. Assim, é possível se aproximarem de suas realidades para intervirem adequadamente.

\subsection{A orientação de pais.}

A importância do papel dos pais/cuidadores na educação, socialização e formação dos filhos é inegável, independentemente dos modos de configuração familiar (Coelho \& Murta, 2007). Para fins didáticos, o termo pais será utilizado neste estudo em seu modo amplo, ou seja, incluindo cuidadores e demais responsáveis pelo cuidado e educação da criança.

Um repertório adequado de práticas educativas e habilidades sociais dos pais possibilita uma convivência familiar mais saudável, além de desenvolvimento infantil mais pleno e comportamentos mais adequados (Del Prette \& Del Prette, 2005). Neste mesmo sentido, déficits dos pais nessa área frequentemente influenciam negativamente as crianças: comportamental, emocional e/ou socialmente. Assim, no intuito de auxiliar as crianças em suas dificuldades torna-se fundamental também ater-se aos pais e às suas dificuldades e construção de recursos necessários ao educar.

Olivares, Mendez e Ros (2005) afirmam que, apesar da importância dos pais, no desenvolvimento e em qualquer intervenção infantil, eles geralmente recebem pouca preparação para educar e criar os filhos, além da própria experiência como pais, aprendizagem essa geralmente feita por tentativa e erro. Acerca do tema, Weber (2005) reforça que, considerando as rápidas transformações e incorporações nas dinâmicas familiares, os pais estão mais carentes de orientações científicas dentro de outro modelo de educação além daquele autoritário em que aprenderam em seu passado.

Compartilhando a mesma percepção, o estudo de Biasoli-Alves (2005) mostra que cada vez mais os pais têm se angustiado com questões relativas ao modo como agem com seus filhos e se questionam se estão preparando-os adequadamente para os desafios da vida. 
Essas dificuldades e dúvidas, aliadas ao aumento e manutenção de problemas emocionais e comportamentais em crianças, têm motivado o desenvolvimento de intervenções dirigidas aos pais, tais como o treinamento de pais, sendo o principal foco da maioria dos grupos dessa modalidade a mudança comportamental infantil.

Problemas comportamentais em crianças se agrupam em duas categorias, de acordo com as catalogações da psicopatologia da infância: os transtornos externalizantes e os internalizantes. Transtornos externalizantes são problemas direcionados à relação da criança com o ambiente e com os outros - englobando os transtornos de comportamentos disruptivos (transtorno de conduta e desafiador opositivo), hiperatividade, agressividade e comportamentos antissociais. Os transtornos internalizantes caracterizam-se por problemas relacionados a experiências internas, como: ansiedade, isolamento e depressão (Kazdin, 2005). Lobo, Flach e Andretta (2011), ao levantar dados epidemiológicos brasileiros, trazem taxas de 10 a 12,7\% da existência de ao menos um diagnóstico psiquiátrico em crianças e adolescentes com maior prevalência entre os transtornos externalizantes opositores e de conduta, apresentando taxas de 7 a 4,4\% (Anselmi, Fleitlich-Bilyk, Menezes, Araújo, \& Luis, 2010; Fleitlich-Bilyk \& Goodman, 2004).

De acordo com Caminha (2011), o treinamento, ou orientação de pais é uma intervenção que envolve programas estruturados e específicos voltados para mudanças de padrões familiares e desenvolvimento de novas práticas educativas. Ele vai além da inclusão parental no tratamento infantil por focar-se exclusivamente nos pais. Este pode ser feito tanto em modalidade individual, quanto grupal. Discute-se, no entanto, que atendimentos em grupo possibilitam que um número maior de pessoas tenha acesso às intervenções psicológicas, além de reduzir custos, otimizando a participação do terapeuta nos serviços públicos de saúde e às práticas preventivas e de promoção de saúde. Viabiliza ainda a utilização de estratégias e fatores terapêuticos específicos que não podem ser aplicados em um tratamento puramente individual (Yalom \& Leszcz, 2006).

De acordo com Lobo, Flatch e Andretta (2011), estudos de metanálise indicam o treinamento de pais como a modalidade de intervenção mais recomendada para o tratamento de transtornos disruptivos em crianças. Sendo amplamente utilizada para o tratamento de transtorno de conduta (Dretzke, et al., 2009), transtorno desafiador opositivo (Costin \& Chambers, 2007), dentre outros problemas externalizantes. O treinamento de pais encontra-se na primeira linha de intervenções baseadas em evidência para crianças pré-escolares com transtornos disruptivos e, em segunda linha, como intervenção complementar ao atendimento clínico, para crianças com até 12 anos (Eyberg, Nelson \& Boggs, 2008). Tratamentos 
baseados em evidências referem-se a intervenções que apresentam suporte empírico de sua eficácia, sendo demonstrada resposta terapêutica e melhoras significativas (Kazdin, 2004). De acordo com o levantamento de Pheula e Isolan (2007), as linhas de pontuação das intervenções baseadas em evidências em psicologia são feitas de linhas 1 a 3 com base em sua provável eficácia, de acordo com a classificação do Hawaii Empirical Basics to Services Task Forces, com base em sua provável eficácia (Chorpita, et al., 2002).

Os resultados e benefícios comumente obtidos pelo treinamento de pais, em suas diversas modalidades, são: aumento da eficiência do tratamento das crianças quando os pais estão em orientação, prevenção e diminuição da ocorrência de problemas de comportamento e a possibilidade de identificação e intervenção precoce nos problemas de comportamento da criança. Além disso, auxiliam que os pais percebam seus próprios comportamentos inadequados que provocam ou mantém os comportamentos problemáticos dos filhos, sendo de grande relevância a continuidade do desenvolvimento dessa área no Brasil (Olivares et al., 2005).

Sobre a terminologia alguns pesquisadores atuais mantêm o nome treinamento de pais para esses programas, no entanto, outros pesquisadores optam por denominá-los de orientação de pais (Marinho, 1999; Neufeld \& Maehara, 2011), terminologia que denota menos rigidez e hierarquia terapeuta-participantes. Esta pesquisa adota a nomenclatura orientação de pais, por ser também a utilizada no "Laboratório de Pesquisa e Intervenção CognitivoComportamental” (LaPICC-USP), do qual o presente estudo faz parte.

Programas de orientação de pais que apresentam enfoque comportamental são indicados para pais de crianças a partir de três anos até a adolescência (Barkley, 1997). De acordo Dishion e Paterson (1992), essa modalidade é efetiva para diminuir problemas de comportamento tanto em crianças pequenas, quanto em mais velhas, embora as crianças mais velhas, acima de sete anos, tenham maior probabilidade de já apresentarem problemas clínicos antes do início da intervenção com os pais. Em um estudo complementar Ruma, Burke e Thompson (1996) identificaram que o aproveitamento de crianças mais velhas e adolescentes, após a intervenção com seus pais, é menor do que a de crianças menores, mas justamente por tenderem a apresentar problemas mais severos e enraizados, sendo a intervenção importante em todas as etapas do desenvolvimento. 


\subsubsection{Histórico da orientação de pais.}

Os primeiros estudos envolvendo a orientação de pais foram feitos na década de 60 , visando à diminuição dos comportamentos indesejados das crianças, que ainda não podiam passar pelo processo psicoterápico (Williams, 1959). De acordo com Marinho (1999), as intervenções em orientação de pais nesse período, tinham o objetivo de combater e auxiliar na resolução de diversos problemas de comportamento infantil, sendo que o terapeuta trabalhava com os pais com objetivo fundamental de conseguir a redução de comportamentos inadequados nas crianças. As intervenções baseavam-se no modelo triádico de atendimento.

Delineado por Tharp e Wetzel (1969) esse modelo pressupõe que a mudança terapêutica não se baseia apenas na interação cliente-terapeuta, mas que necessita também de outra pessoa significativa para o cliente, que participe ativamente de todo o trabalho. Essa pessoa atua como mediadora, aplicando as intervenções recomendadas pelo terapeuta e auxiliando no planejamento das intervenções, selecionando comportamentos que devem ser trabalhados e modificados (Pardo \& Carvalho, 2011).

Os pressupostos básicos do modelo triádico são: os comportamentos inadequados não devem ser reforçados, os adequados necessitam de reforço e é o mediador que deve reforçar ou não os comportamentos. No caso de orientação de pais, os mediadores são os pais, justamente por terem uma visão mais ampla dos comportamentos infantis e do que necessita ser modificado (Silvares, 1995). O modelo ainda é muito utilizado por terapeutas comportamentais em orientação de pais e na clínica infantil. De acordo com Prebianchi (2011) e Stern (2003), o reconhecimento dos pais como mediadores, tornando-se agentes efetivos para a mudança comportamental dos filhos, tem levado ao desenvolvimento e avaliação de diversos programas de treinamento de pais na atualidade.

Na década de 70 os estudos de orientação de pais se expandiram. Sua utilização para modificação comportamental infantil prosseguiu. Essa modalidade passou a ser adotada também para tratamento de diversos problemas clínicos infantis, como agressividade, déficit de aprendizagem, enurese, problemas de sono e alimentação, problemas escolares, entre outros (Marinho, 1999). A autora destaca também que, nas décadas seguintes, objetivos relacionados com a interação familiar foram abarcados nas temáticas da orientação de pais, como crises conjugais e a própria relação pais-filhos, depressão materna, problemas financeiros, entre outras dificuldades que acabavam afetando as relações familiares. Outra modificação percebida é que os terapeutas passaram não só a tratar as crianças e orientar os pais em aspectos específicos, mas começaram a se preocupar também em prepará-los para a 
identificação e a resolução de problemas infantis em casa, enfatizando aspectos de psicoeducação (Caminha, 2011).

Nas décadas mais atuais, de acordo com Bolsoni-Silva, Silveira e Ribeiro (2008), percebe-se na literatura uma ligeira diminuição do número de programas e intervenções em orientação /treinamento de pais, embora os problemas comportamentais infantis tenham aumentado e ainda exista clara demanda. Defendendo o mesmo posicionamento que incentiva o desenvolvimento de mais intervenções em orientação de pais, Marinho (1999) afirma que é necessário que as pesquisas e intervenções mais atuais e orientação de pais considerem o desenvolvimento de estratégias que permitam a generalização e a manutenção das mudanças comportamentais obtidas após o tratamento, além de mudarem o foco da intervenção, de comportamentos-problemas da criança para o desenvolvimento de comportamentos prósociais.

Observa-se hoje também uma tendência de expansão para um olhar para a família e não apenas do comportamento infantil. Incorpora-se, nas intervenções com pais, cada vez mais as variáveis relacionais pais-filhos, as percepções dos pais sobre as crianças e sobre eles mesmos, além de serem incentivadas análises das dinâmicas familiares (Marinho, 1999; Weber, 2008).

\subsubsection{Alguns componentes comuns da orientação de pais.}

Apesar da multiplicidade de possibilidades envolvidas na orientação de pais atuais, a maioria dos programas compartilha alguns componentes para uma melhor interação familiar. Tratam-se das Práticas Educativas Parentais, Estilos Parentais e Habilidades Socais Educativas Parentais. As características e importâncias de cada um desses temas para orientação de pais são destacadas a seguir.

As práticas educativas referem-se às estratégias utilizadas pelos pais para atingirem objetivos específicos na educação de seus filhos. O uso de explicações, diálogos, punições, elogios, entre outros, com finalidades específicas, como ensinar o cumprimento de regras, reforçar comportamentos adequados ou punir os inadequados são exemplos de práticas educativas utilizadas pelos pais (Cecconello, De Antoni, \& Koller, 2003).

As práticas educativas adotadas pelos pais são de grande importância para o desenvolvimento infantil e para o repertório comportamental e social da criança, sendo um dos temas mais abordados na orientação de pais. Diversos estudos relatam que as práticas parentais tanto podem influenciar o aparecimento ou a manutenção de problemas de 
comportamento infantil como atuarem como fator de proteção para o desenvolvimento, prevenindo problemas comportamentais, sociais e emocionais das crianças (Bolsoni-Silva \& Marturano, 2010; Gomide, 2004; Weber, 2005).

Entre as práticas educativas avaliadas como prejudiciais ao desenvolvimento e educação dos filhos estão: disciplina inconsistente dos pais, pouca interação positiva, baixo envolvimento e monitoramento, baixa afetividade, negligência e monitoria insuficiente. Já as práticas positivas envolvem comunicação clara e eficaz, afeto, envolvimento, expressão de sentimentos, monitoria positiva e uso adequado de limites e regras (Bolsoni-Silva, SalinaBrandão, Versuti-Stoque, \& Rosin-Pinola, 2008; Cecconello et al., 2003; Gomide, 2006).

Por sua vez, os estilos parentais referem-se a um padrão global de características da interação dos pais com os filhos, incluindo as práticas parentais que mais utilizam e outros aspectos da relação com os filhos, como tom de voz, linguagem corporal, mudança de humor. Os Estilos Parentais estabelecem climas emocionais preponderantes de educação dos filhos (Cecconello et al., 2003; Weber, Prado, Viezzer, \& Brandenburg, 2004). São, portanto, modos mais estáveis e enraizados de educação, que são frequentemente influenciados pela história de vida dos pais, pela educação que tiveram e pela forma de interação com seus pais e filhos.

Os estilos podem ser mais ou menos adequados para o desenvolvimento dos filhos. Assim, trabalhar os estilos parentais em orientação de pais é importante para alcançar flexibilização dos estilos menos adaptativos às crianças e aprendizado de formas mais adequadas de educar e se relacionar com os filhos (Salvador \& Weber, 2008). Por sua característica mais global e comumente enraizada a partir da história de vida e educação dos próprios pais, torna-se relevante abordar não só os comportamentos e práticas envolvidos nos estilos parentais menos adaptativos, mas também os aspectos cognitivos e emocionais envolvidos no papel de educar.

Outra temática que vem sendo inserida nos programas de orientação de pais refere-se às habilidades sociais educativas parentais (HSE-Ps), que corresponde ao conjunto de comportamentos sociais habilidosos dos pais na educação de seus filhos. São exemplos: a assertividade em estabelecer regras, clareza na comunicação, capacidade de manejar suas próprias emoções na hora de educar, entre outros (Bolsoni-Silva, 2000).

De acordo com Bolsoni-Silva e Marturano (2002) HSE-Ps mais adequadas favorecem o aumento do repertório de comportamentos socialmente adequados da criança, além de aproximar mais pais e filhos. Sendo então fundamentais comportamentos socialmente habilidosos dos pais para a condução de práticas educativas adequadas com os filhos. 
Trabalhando em conjunto as práticas parentais positivas, os estilos parentais adaptativos e as HSE-Ps aumentam-se as chances de auxiliar os pais de forma mais completa e eficaz na educação de seus filhos. No entanto, nem sempre todos esses elementos podem ser trabalhados na mesma proporção, sendo necessário um planejamento cuidadoso de acordo com as características do próprio programa de orientação de pais a ser adotado, para identificar qual das três instancias é mais importante ou viável de ser trabalhada naquele contexto.

\subsubsection{Programas de orientação de pais e a promoção de saúde}

São diversos os programas desenvolvidos para orientar ou treinar pais em suas dificuldades de educação dos filhos em todo o mundo. Para justificar a proposição de um programa de orientação de pais no presente estudo, torna-se importante descrever alguns programas que vem sendo utilizado para orientação familiar que apresentem ou permitam o foco preventivo e de promoção de saúde, sobretudo os desenvolvidos para a população brasileira.

Dentre os programas mais citados na literatura internacional estão:

O Parent Management Training-Oregon Model (PMTO), programa de treinamento de pais pautado na abordagem comportamental, desenvolvido originalmente por Patterson (1974). Volta-se para pais de crianças e adolescentes com problemas disruptivos clínicos, tais como comportamento antissocial, problemas de conduta, roubos, delinquências, abuso de substâncias, além de casos de negligência infantil e abuso na família. Estudos randomizados com a aplicação do programa mostraram efetividade do treinamento e melhora dos problemas de condutas e opositivos das crianças/adolescentes e nas práticas educativas familiares.

O PMTO pode ser aplicado em diversos formatos, como: grupos de pais, tratamento familiar individualizado, livros e fitas de áudio e vídeo. Após evidências da eficácia do mesmo, coletadas há cerca de 40 anos, passou a ser aplicado também no contexto preventivo, para pais de pré-adolescentes com risco de abuso de substâncias, para mães recém divorciadas, para famílias com filhos de casamentos anteriores e famílias moradoras de áreas de elevada criminalidade, também enfocando a diminuição de comportamentos disruptivos. (Patterson, 2005)

Outro programa é o Incredible Years, desenvolvido por Webster-Stratton (1991). O Incredible Years embasa-se na teoria de aprendizagem social e foi elaborado originalmente como intervenção precoce para prevenção de problemas de comportamento infantil, tais como 
transtorno desafiador opositivo e problemas de conduta. Este programa foi desenvolvido em séries, voltadas para pais, professores e crianças de dois a oito anos. Uma das séries é direcionada diretamente aos pais, no formato de treinamento parental em três estágios. $\mathrm{O}$ estágio básico enfoca habilidades parentais como disciplina, regras e limites, estabelecimento de recompensas e punições, entre outros e é realizado em casa, através de material digital de apoio. $\mathrm{O}$ avançado ensina aos pais habilidades de resolução de problemas, manejo de raiva e habilidades de comunicação. O terceiro estágio ensina aos pais habilidades relacionadas à aprendizagem de seus filhos, tais como: estimulação de aprendizagem acadêmica, estabelecimento de rotina de estudos, habilidades de leitura, acompanhamento escolar e suporte para realização de tarefa de casa. Outra série do Incredible Years volta-se exclusivamente para professores e é realizada com as crianças em conjunto em sala de aula (Webster-Stratton, 2005).

O programa foi aprimorado diversas vezes e os resultados de sua aplicação foram coletados por um período de 30 anos de pesquisa. Eles indicam melhorias nas habilidades sociais e emocionais infantis e nas competências acadêmicas das crianças e melhorias na interação pais-crianças-professores, visando prevenção de problemas de desenvolvimento, familiares e escolares. (Webster-Stratton \& Reid, 2010)

O Strengthening Families Program (SFP) (Kumpfer, Molgaard, \& Spoth, 1996) é outro programa de orientação de pais pautado na abordagem comportamental, sendo originalmente desenvolvido em um formato de 14 sessões. Voltava-se para famílias de elevado risco por abuso de substâncias, com filhos de seis a 11 anos de idade. O programa visa o treinamento de habilidades educativas para pais e filhos e atualmente, volta-se tanto para famílias de elevado risco quanto às de baixo risco. Também pode ser aplicado em formatos variados, tendo sido desenvolvido programas mais curtos, com 10 sessões, para famílias de baixo risco e ampliado a adolescentes mais velhos de 10 a 16 anos. Material de vídeo para treinamento individual em casa e escola também foram desenvolvidos. Além de treinamento de pais, o SFP em seus diversos formatos ensina habilidades diretamente às crianças que devem ser treinadas com auxílio dos pais.

Os SFP foi aplicado em diversos contextos e países e seus resultados mostram redução significativa de problemas de comportamento, delinquência, abuso de drogas e melhora nas competências sociais infantis e no desempenho escolar. Estudos atuais mostram também decréscimo de maus tratos infantis, aprendizagem de habilidades parentais e fortalecimento de laços familiares (Kumpfer, Pinyuchon, Melo, \& Whiteside, 2008). 
Os três programas apresentados possuem resultados efetivos na redução de problemas infantis, melhora de habilidades parentais e fortalecimento de laços familiares. Foram todos replicados em diversos contextos e países e se ramificaram para prevenção de problemas de comportamento e desenvolvimento infantil, além de cuidar dos vínculos familiares. São programas com mais de oito sessões e que possuem materiais próprios para o treinamento e avaliação. São aplicados por multiplicadores que passam por treinamento prévio de capacitação e enfocam pais, crianças, adolescentes e podem ser treinados também com professores.

Certamente muitos outros programas internacionais têm expressividade no campo da orientação de pais, contribuindo muito para área. Os apresentados são exemplos de programas que se ramificaram para populações não clínicas visando a prevenção de doenças mentais e condições negativas de desenvolvimento e promoção de saúde.

No Brasil, a literatura em intervenções com orientação de pais, é um pouco mais escassa, mas elas também podem ser encontradas em diversos contextos. Alguns exemplos são os grupos de orientação de pais direcionados a tratamento de problemas de comportamento infantil (Bolsoni-Silva \& Marturano, 2007; Bolsoni-Silva, Silveira, \& Marturano, 2008); os focados no manejo de adversidades oriundas de deficiências ou condições médicas infantis (Motti \& Pardo, 2010); os específicos a transtornos psicológicos de crianças (Porto, 2005; Serra-Pinheiro, Guimarães, \& Serrano, 2005) e os grupos de orientação de pais como alternativa ou complemento ao atendimento de crianças ou em lista de espera em serviços-escolas de psicologia (Marinho, 1995; Neufeld \& Maehara, 2011).

Acerca dos programas brasileiros de orientação de pais, Bolsoni-Silva, et al. (2008) propõem a divisão dos estudos em trabalhos com caráter remediativo e trabalhos que enfocam o desenvolvimento e treino de habilidades parentais para prevenção de problemas de comportamentos e para promoção de saúde. Apesar de muitas vezes utilizados em conjunto, prevenção e promoção de saúde são conceitos diferentes. Podem ter sido unidos nessa classificação por sua possível complementaridade ou até mesmo pela escassez de estudos com esse enfoque, sendo categorizados pelas autoras em conjunto.

É usual que programas de orientação de pais em grupos visem tanto à prevenção de psicopatologias na infância quanto à promoção de saúde, para um desenvolvimento infantil mais saudável e adaptativo e para melhores relações familiares entre pais e filhos (Weber et al., 2006). Faz-se necessário, inicialmente introduzir esses conceitos para posterior compreensão de como a orientação de pais pode ser inserida como prática para promover saúde, bem como as características de programas e estudos que a enfocam. 
De acordo com Czeresnia (1999), a prevenção em saúde se dá pela ação antecipada com o objetivo de tornar improvável o progresso da doença ou problemas. Visam reduzir a incidência ou prevalência de dificuldades, em locais em que são propensas. O termo promoção define-se, de maneira mais ampla, a não se direcionar a uma determinada doença ou desordem, mas objetiva aumentar a saúde e o bem estar de uma forma global. Para Buss (2000), promover saúde envolve um conjunto de valores como qualidade de vida, saúde, solidariedade, equidade, democracia, cidadania, desenvolvimento, participação e parceria, entre outros. Refere-se também a uma combinação de estratégias: ações do Estado, da comunidade, de indivíduos, do sistema de saúde e de parcerias entre os setores de assistência.

Caminha, Soares e Kreitchmann (2011) apresentam os principais fatores para serem trabalhados direta ou indiretamente em grupos de orientação de pais voltados para a promoção de saúde. São eles: o apego ou vínculo afetivo, as necessidades fisiológicas infantis básicas (alimentação e sono), a necessidade de brincar, a de regras e limites, a de segurança, de autonomia, a de toque e carinho e o manejo adequado de emoções.

Quando se consideram todos esses fatores, é possível propor programas de orientação de pais mais completos e eficazes voltados tanto à promoção de saúde, quanto à prevenção e tratamento de problemas comportamentais infantis. Como o destaque desta pesquisa ocorre sobre a promoção de saúde, serão enfatizados alguns programas que se enquadram na segunda categoria de Bolsoni-Silva, Salina-Brandão et al. (2008) e que foram relevantes para a elaboração e aplicação do programa de orientação de pais apresentado no presente estudo.

Segundo as mesmas autoras, a maioria dos estudos preventivos ou de promoção de saúde é realizada em grupos, com duração de 10 a 16 sessões e com frequência semanal. Nessa categoria de programas, foram realizados no Brasil estudos com diferentes enfoques, visando por exemplo, melhorias na qualidade da interação familiar (Weber et al., 2006), desenvolvimento de habilidades sociais educativas parentais em pais de criança sem demanda clínica (Silva, et al., 2000) e os grupos vivenciais de mães para troca de experiências (Arruda, 1989).

Alguns dos programas brasileiros em promoção de saúde são: O programa desenvolvido por Silva et al. (2000), com abordagem comportamental, realizado em 10 sessões de uma hora e meia, enfocando habilidades sociais educativas parentais necessárias para um bom vínculo familiar e educação infantil. Os resultados relatados mostraram aumento da consciência dos pais acerca de suas dificuldades e erros e motivação para melhorar, no entanto, mostraram dificuldades em deixar o uso da punição. 
O programa de qualidade na interação familiar (PQIF) (Weber et al., 2006), também de abordagem comportamental é realizado em oito sessões com duração de uma hora e meia. Volta-se para pais de crianças sem clara demanda clínica, visando melhorar a qualidade de interação familiar, mediante a aprendizagem e treinamento de práticas educativas parentais mais adaptativas. Os resultados da aplicação do PQIF, avaliado através das Escalas de Qualidade na Interação familiar (versão filhos) sugerem mudanças, como o aumento do envolvimento na vida dos filhos, maior clareza e consistência no estabelecimento de regras, aumento das práticas educativas positivas e diminuição das punições, contribuindo para a qualidade da interação familiar.

Objetivando ampliar o programa elaborado por Silva (2000), Bolsoni-Silva, et al. (2008) apresentam outro programa que pode ser utilizado para melhoria da interação familiar. Composto por 14 sessões, este programa na abordagem comportamental visa ensinar os pais acerca das leis do comportamento e incentivá-los a observar e descrever a relação entre os comportamentos infantis e suas práticas parentais, além de realizar o treinamento de HSE-Ps. Os resultados do programa, mensurados através do Questionário de Habilidades Sociais Educativas Parentais (QHSE-P, adaptação de Bolsoni Silva, 2003) apontam para a aquisição de algumas habilidades educativas parentais, tais como expressar sentimento positivo, manter conversação, evitar o uso de práticas punitivas e estabelecer limites de conversação, bem como sinalizam o aprendizado de generalização de algumas habilidades para além do contexto parental, sugerindo melhoras na quantidade de interações entre pais e filhos e outras pessoas da convivência dos participantes.

O destaque para os estudos acima foi feito por serem programas estruturados, que tem entre seus objetivos prevenir problemas e promover relações familiares mais saudáveis. Muitos outros estudos brasileiros com orientação de pais, que resultaram em programas interventivos, têm características mistas, ou seja, visam ajudar os pais a manejarem problemas comportamentais das crianças, mas também prevenir problemas, promover saúde familiar e um melhor desenvolvimento infantil (Bolsoni-Silva, et al,2008)

Alguns instrumentos, além dos citados, estão disponíveis para avaliação de intervenções em orientação de pais. Um breve levantamento dos instrumentos brasileiros disponíveis na literatura (Teodoro, 2012) e validados no Conselho Federal de Psicologia, é importante para contextualização dessa modalidade de intervenção no País e, para a justificativa da escolha de instrumentos realizada no presente estudo.

Apesar de não se voltar especificamente para avaliação de intervenções em orientação de pais, a Entrevista Familiar Estruturada (EFE) (Féres-Carneiro, 1997, 2005), trata-se de uma 
entrevista clínica para diagnóstico de interação e dinâmica familiar. É validade pelo Conselho Federal de Psicologia e realizada com os membros da família em conjunto, não enfocando diretamente práticas parentais e sim as relações familiares como um todo, tendo sua duração de aplicação de 30 a 90 minutos.

O Inventário de Percepção do Suporte Familiar (IPSF) (Baptista, 2009) é uma escala aprovada pelo Conselho Federal de Psicologia que avalia o suporte familiar em três características: expressão de afetividade entre os membros da família, adaptação familiar (sentimentos e comportamentos negativos em relação à família) e autonomia entre os membros (noções de liberdade, confiança e privacidade). Volta-se para adolescentes e adultos que respondem acerca de sua própria família. Não é específico para avaliação de práticas educativas que os pais aplicam a seus filhos.

Um instrumento muito utilizado na avaliação treinamento de pais é o Inventário de Estilos Parentais (IEP) (Gomide, 2006), também validado pelo Conselho Federal de Psicologia, esse instrumento investiga os estilos parentais e sua influência em sete práticas educativas dos pais: monitoria positiva, comportamento moral, abuso físico, disciplina relaxada, monitoria negativa e punição inconsistente. Por enfocar-se nos estilos parentais, que, como já mencionado, são padrões mais globais e enraizados de educação, pode ser difícil utilizar esse instrumento para uma intervenção muito breve, com curto espaço para mudanças.

O Roteiro de Entrevista de Habilidades Sociais Educativas Parentais (RE-HSE-P) (Bolsoni-Silva, Loureiro, \& Marturano, 2011) é um roteiro de entrevista com 13 questões sobre as habilidades sociais dos na educação de seus filhos, o instrumento é a versão final do Questionário de Habilidades Sociais Educativas Parentais (QHSE-P), anteriormente mencionado. Para avaliação com o Roteiro, a entrevista deve ser gravada e transcrita, para posterior avaliação qualitativa e quantitativa. A aplicação da entrevista tem duração média de uma hora. Esse instrumento foi utilizado em uma experiência piloto do presente estudo, não publicada. Os itens da entrevista contemplavam as questões necessárias para avaliar as práticas educativas e a interação entre pais e filhos, no entanto, os pais apresentaram muita resistência em responder à entrevista, queixando-se de falta de tempo para a avaliação e mantendo respostas monossilábicas como "sim" e "não", apesar das tentativas dos terapeutas em abordar e aprofundar todos os tópicos da entrevista. Por conta das características dessa população, o instrumento não foi incorporado nesse estudo. cognitivo-comportamental e a orientação de pais 
Como ressaltado a maioria dos programas descritos na literatura, nacional e internacional, embasam-se no enfoque comportamental e ensinam e treinam os pais para observar e modificar os comportamentos inadequados infantis. Além de contribuir para a correção dos comportamentos inadequados paternos objetivauma educação mais eficaz e também mais afetuosa.

Apesar da inegável importância de se olhar para comportamentos das crianças e dos pais no papel de educadores, há outros aspectos fundamentais que não estão presentes na maioria dos protocolos como as emoções e as cognições, esta ultima ainda muito pouco abordada na literatura de orientação de pais. Acerca da inclusão do aspecto cognitivo, Caminha (2011) ressalta que reflexões do tipo: "como vejo meu filho", "como avalio meu papel de pai", "como quero educar meu filho" e "como os comportamentos do meu filho me afetam", podem beneficiar o aprendizado e a fixação de conteúdo em intervenções dessa modalidade.

Os conteúdos cognitivos inseridos na orientação de pais derivam do modelo cognitivo de Beck (1963), foi inicialmente direcionado ao tratamento de depressão e posteriormente adaptado para outros contextos e queixas, o modelo propõe que a sintomatologia e problemas dos pacientes podem ser explicados cognitivamente, por meio de interpretações tendenciosas ou distorcidas acerca de si, dos outros e do futuro, interpretações estas que modulam seus comportamentos e emoções. A reestruturação cognitiva é uma ferramenta que possibilita a modificação de regras e crenças disfuncionais básicas dos pacientes, levando a melhora no comportamento e humor dos mesmos (Beck, 1997; Knapp \& Beck, 2008).

A principal estratégia para realizar essa reestruturação é a conceitualização cognitiva, estratégia terapêutica na qual se traça um mapeamento ou panorama do funcionamento do cliente, incorporando pensamentos automáticos mais frequentes, crenças regras, crenças centrais, comportamentos, emoções e demais consequências que acompanham essas crenças. A conceitualização, embora seja uma ferramenta clínica amplamente utilizada no atendimento individual, pode ser traçada também em grupos (Neufeld \& Cavenage, 2010).

No contexto de orientação de pais, inserir o modelo cognitivo, com foco na compreensão das relações entre as praticas educativas e os comportamentos infantis, é importante, mas desafiador. Neufeld e Maehara (2011) destacam que as principais dificuldades observadas abarcam a compreensão do modelo cognitivo por parte dos pais e a realização da conceitualização cognitiva das crenças relacionadas à interação com as suas crianças, conseguindo acompanhar com mais facilidade apenas o primeiro nível de cognição: os pensamentos automáticos. 
Os três níveis de cognição preconizados por Beck (1963) e que compõem a conceitualização cognitiva, ao lado de comportamentos e sentimentos são: Os pensamentos automáticos, nível mais superficial, são pensamentos espontâneos e fluem na mente a partir dos acontecimentos cotidianos; as crenças intermediárias, que ocorrem na forma de pressupostos ou regras, refletindo ideias mais enraizadas; e as crenças centrais, o nível mais profundo, que corresponde às ideias e percepções consideradas pela pessoa como verdades absolutas e imutáveis (Caminha, Wainer, Oliveira, \& Piccoloto, 2003).

Apesar das dificuldades em adentrar os dois componentes mais profundos da cognição, investir na inclusão de aspectos cognitivos na orientação de pais parece ampliar e contribuir para a aquisição de habilidades educativas parentais e as relações intrafamiliares. Um dos poucos estudos brasileiros que abordam esses aspectos na orientação de pais em grupo e corroboram com essa visão é o de Caminha, Bellé e Pelisoli (2007): voltado para pais de crianças com fobias específicas. Este inclui discussões e estratégias para a modificação das crenças e sentimentos dos pais em relação às dificuldades que encontram no educar e no manejo do tratamento das crianças. Os resultados do estudo apontam que quanto maior a conscientização dos pais sobre suas formas de educar e seus papéis, maiores possibilidades de melhora do comportamento infantil e melhor a utilização e manutenção de práticas parentais adequadas. Fornecendo evidências que a inclusão dos aspectos cognitivos na orientação de pais tem grande importância.

Neufeld e Maehara (2011), com o programa PROPAIS-USP também contribuem para a inclusão dos aspectos cognitivos em orientação de pais, tanto na compreensão dos participantes sobre sua função de educador quanto na preocupação com os sentimentos das crianças. $\mathrm{O}$ estudo enfoca também possíveis pensamentos que podem desprender das práticas educativas dos pais, visando um bem estar geral tanto dos pais quanto das crianças. Este programa, desenvolvido em 11 sessões estruturadas, volta-se para pais de crianças em atendimento psicológico em serviço-escola. Trata-se de um dos poucos programas brasileiros estruturados que insere aspectos cognitivos na intervenção com os pais e, é de grande importância para o presente estudo, por ter fornecido base para a construção do programa proposto.

A expressiva dificuldade de encontrar na literatura nacional e internacional programas de orientação de pais que considerem o enfoque cognitivo é magnificada quando se buscam esse tipo de intervenção realizado na área de promoção de saúde. Carvalho (2000) destaca que o próprio enfoque contemporâneo de pesquisa valoriza projetos globais que sejam capazes de articular sociedade, comunidade e a família, tais como os estudos de promoção de 
saúde. Coelho e Murta (2007) validam a contribuição da orientação de pais para serviços preventivos, de tratamento e de promoção de saúde, sendo que os avanços nessa área podem auxiliar tanto a clínicos e pesquisadores, como a gestores em políticas públicas de educação, saúde e assistência social à infância e adolescência.

Nesse sentido mais global, o presente estudo visa propor e investigar um programa cognitivo-comportamental de orientação de pais voltado à Promoção de Saúde, denominado PROPAIS II. O programa volta-se para pais de crianças com idade correspondente à terceira infância do desenvolvimento. Este se trata de um período com grandes novidades na vida da criança, como a adaptação à escola, a aprendizagem de novos conteúdos e intensificação do convívio social (Papalia, Olds, \& Feldman, 2006). Por ser uma fase de grandes desafios, pode facilitar o surgimento de problemas de comportamento, sendo importante para a promoção de saúde prevenir que tais problemas apareçam ou se agravem. O que tende a ocorrer com o aumento da idade das crianças, conforme destacado por Ruma, et. al.(1996). 


\section{Objetivos}

\subsection{Objetivos gerais}

Propor e avaliar os resultados imediatos do programa PROPAIS II em grupos de curta duração, visando o contexto de promoção de saúde.

\subsection{Objetivos específicos}

- Implementar o PROPAIS II em duas instituições não governamentais complementares á educação de crianças em idade escolar e em finalização da etapa pré-escolar.

- Caracterizar a amostra estudada através de indicadores socioeconômicos, percepção dos pais sobre problemas de comportamento dos filhos e de práticas parentais e interação familiar.

- Avaliar os efeitos das variáveis dependentes: práticas educativas parentais/interação familiar e problemas comportamentais infantis, através da comparação dos escores obtidos na pré e pós-testagem dos participantes.

- Avaliar qualitativamente, por meio dos relatos das falas registradas nas sessões, as impressões e experiências suscitadas nos membros pela participação nos grupos. 


\section{Método}

\subsection{Contexto da pesquisa.}

O PROPAIS II originou-se de uma adaptação e expansão do programa PROPAISUSP, também conhecido como PROPAIS I (Neufeld \& Maehara, 2011). Este último é um programa cognitivo-comportamental, de 11 sessões e foi desenvolvido no LaPICC-USP, sendo aplicado desde 2009, voltando-se para pais de crianças que estão em atendimento em Clínica Escola.

Em 2011 o PROPAIS II foi elaborado, voltando-se para pais de crianças sem clara demanda clínica, visando promoção de saúde e prevenção de problemas de interação familiar. Com conteúdo semelhante ao aplicado PROPAIS- USP, diferenciou-se pela diminuição do número de sessões: de onze para seis, que passaram a ser trabalhadas de forma mais integrada e pautada no cotidiano das famílias. Essa diminuição foi realizada após experiência piloto, na qual se verificou necessidade de ajustamento da quantidade e formato das sessões, que abarcassem os conteúdos fundamentais do programa, sem sobrecarregar a rotina dos participantes, que mostraram dificuldades em comparecer às instituições por um maior período de tempo.

Quanto aos temas propostos no PROPAIS II, todos adotaram maior caráter psicoeducativo, visando auxiliar aos pais compreenderem as principais características e dificuldades na educação dos filhos. A linguagem dos terapeutas foi também adaptada, com diminuição do uso de termos técnicos da psicologia e incorporação de exemplos concretos do dia a dia, após os terapeutas conhecerem um pouco da rotina das famílias nas primeiras sessões, visando facilitar o aprendizado e a apropriação dos conteúdos pelos participantes.

O conteúdo das seis sessões do PROPAIS II (Anexo A) abarca temas comportamentais, cognitivos e emocionais. Na elaboração de cada encontro, os terapeutas são preparados para atentar-se a realidade relatada por cada participante sobre sua família e sobre as crenças que tenham acerca da educação de seus filhos, a fim de auxilia-los sempre dentro do cotidiano de cada pai.

A presente pesquisa relata a aplicação desse programa em seis grupos, realizados em duas instituições não governamentais. Anteriormente, para fins de contextualização, será 
brevemente descrita a experiência inicial de implantação do PROPAIS II, realizada em escola municipal.

No ano de 2011, o programa foi oferecido pela primeira vez em uma escola parceira do LaPICC-USP, na qual já ocorriam grupos interventivos e psicoeducativos com crianças para treinamento de habilidades de vida desde 2009 (Neufeld, Daolio, Cassiano, Rossetto, \& Cavenage, 2014). A coordenação pedagógica da instituição manifestava o desejo de oferecer orientações às famílias dos alunos. Ele foi iniciado na escola, para os pais de alunos da terceira série, ano este escolhido pela coordenação da escola para início do trabalho, que seria ramificado posteriormente para as outras turmas.

Para iniciar a implantação foi realizada uma reunião geral de pais e explicado sobre o programa. Diversos pais manifestaram interesse, no entanto não houve adesão ao grupo: três pais foram à sessão inicial, mas apenas um continuou após a $2^{\mathrm{a}}$ sessão participando apenas um pai em mais de três encontros. A esse pai foi oferecida a possibilidade de continuar os conteúdos previstos para o grupo ou orientá-lo em suas dúvidas específicas. No entanto ele optou por não continuar a frequentar, sendo realizado apenas um fechamento com ele no terceiro encontro. Não foi realizado pós-teste devido ao baixo número de sessões. Foram feitas mais duas tentativas de formar grupos nessa instituição, mas a baixa adesão se manteve.

A possibilidade de fechamento da proposta foi avaliada com a coordenação e diretoria, que preferiram o encerramento, alegando que os pais tinham muita dificuldade de frequentar a escola, mesmo nas reuniões pedagógicas trimestrais. Assim, foi oficializado o encerramento da parceria com a escola para realização dos grupos de orientação de pais.

Duas outras parcerias do LaPICC-USP foram firmadas, um núcleo de fortalecimento de vínculos e um centro educacional infantil, ambas as instituições não-governamentais. A parceria com o núcleo iniciou-se em 2012, com o oferecimento do PROPAIS II e outras atividades de estágio do Laboratório, direcionada especificamente às crianças. Nessa instituição, duas intervenções diferentes nunca eram sobrepostas com as mesmas famílias, para evitar inferências das intervenções.

No inicio de 2013 se confirmou a parceria com a outra para realização apenas de grupos de orientação de pais. A descrição de ambas as instituições encontra-se em sequencia:

O núcleo de fortalecimento de vínculos trata-se de uma instituição não governamental de fortalecimento de vínculos, para crianças e adolescentes de seis a 15 anos no período de contra turno escolar. Tem como objetivo principal estimular a convivência e estender a rede de apoio social, a fim de protegê-los da vulnerabilidade instaurada no território do bairro em 
que se localizam, tais como drogadição, evasão escolar, violência doméstica, entre outros. Além disso, busca defender os direitos inerentes a essa faixa etária.

Atualmente atende cerca de 180 crianças, distribuídas de acordo com sua faixa etária em diversas turmas. A instituição oferece oficinas de artes, comunicação, culinária, aulas de dança, esportes, inclusão digital, meio ambiente, música/coral, tear e teatro. Outras atividades oferecidas incluem a participação da comunidade, o acompanhamento de gestantes, encaminhamentos para setores diversos da saúde e projetos de profissionalização dos jovens através da gastronomia em cozinha própria localizada na instituição.

O centro educacional infantil trata-se de uma escola não governamental de educação infantil integral, fundada por irmãs dominicanas. Caracteriza-se como uma associação civil, sem fins lucrativos de caráter educacional, de assistência à saúde e de assistência social. Atende cerca 100 famílias em situação de vulnerabilidade social, residentes na proximidade da escola. A instituição objetiva promover a inclusão social de crianças e adolescentes, por meio de ações socioeducativas, visando à educação, o exercício da cidadania, a autoestima, a dignidade e a justiça. Oferece educação infantil e complementação educacional a crianças em idade escolar através de oficinas diversas e atividades, como apoio pedagógico, artes, leitura e cidadania, visando promover o desenvolvimento saudável das crianças.

\subsection{O programa PROPAIS II.}

O programa é composto de seis sessões interventivas que enfocam prioritariamente práticas educativas parentais e habilidades sociais educativas parentais e uma sessão de avaliação final e encerramento. Conta também com dois encontros para testagem: um anterior e um após a intervenção.

As sessões são estruturadas, mas permitem flexibilizações de acordo com as demandas e características dos participantes. A base de cada um das sessões está descrita em detalhes abaixo:

\section{Primeira sessão:}

$\mathrm{Na}$ primeira sessão todos os participantes do grupo se apresentam e tem a oportunidade de se conhecerem melhor e conhecer os terapeutas. Por mais que alguns pais já possam se conhecer por terem filhos matriculados em uma mesma instituição, nem sempre 
eles têm a oportunidade de conversarem acerca da educação dos filhos e das dúvidas que possui.

O primeiro encontro do grupo é então todo voltado para apresentações, fortalecimento de vínculo e incentivo da coesão grupal. Para que esse objetivo seja alcançado é feito uso de algumas dinâmicas de apresentação (ou "quebra-gelo"). A mais utilizada no programa PROPAIS II é a que se cria uma caixinha de perguntas, respostas e atividades. Nessa dinâmica, adaptada de Weber, et al (2006), após todos terem se apresentado brevemente, com nome, número e idade dos filhos, os participantes sorteiam pequenos papéis de dentro de uma caixa, que vão passando de mão em mão em roda. Os papéis, previamente preparados pelos terapeutas, contêm perguntas sobre: si próprios (por exemplo: atividade preferida, algo que não gosta de fazer, pequenos planos futuros) sobre seus filhos (por exemplo: comida preferida, brincadeira preferida, coisa que não gosta de fazer) e sobre a relação entre eles (por exemplo: atividades ou brincadeiras que gostam de fazer juntos, impressões que acreditam que os filhos possam ter sobre o participante, pequenas dificuldades que encontram no dia a dia).

Dessa forma os pais podem se apresentar e contar um pouco acerca de seus filhos e da relação que possuem, possibilitando que todos se conheçam melhor. Após algumas rodadas de perguntas e respostas, o terapeuta apresenta a todos em conjunto a proposta do grupo: orientar e auxiliar nas dificuldades que possam ter na educação e criação de seus filhos e permitir que os participantes possam trocar experiências entre si, juntamente com as orientações do terapeuta, no objetivo de contribuir para melhoria da interação familiar.

É realizado também o contrato grupal, estabelecendo horário e duração das reuniões, solicitando presença e comprometimento dos participantes e estabelecendo as regras básicas de convivência do grupo. Após o contrato, os coordenadores retomam as principais dificuldades sinalizadas pelos pais na rodada de apresentação e nos instrumentos do pré-teste, de forma coletiva e introduz a primeira temática do programa: A psicoeducação sobre habilidades sociais educativas parentais (HSEPs), em que algumas habilidades gerais, como afetividade, empatia, regras e limites e consistência são explicadas para os participantes, bem como sua importância para uma educação mais saudável e eficaz. Através de conversação, os terapeutas estimulam os participantes a contar um pouco como percebem a aplicação e importância do tema em suas casas e as dúvidas que possuem, a fim de mapear algumas das dificuldades e pontos fortes de cada um dos participantes, a fim de que possam ser melhor trabalhadas nos próximos encontros. 


\section{Segunda sessão:}

Esta sessão possui caráter prioritariamente psicoeducativo e é dividida em duas etapas. O objetivo principal da primeira etapa é ensinar e dialogar com os participantes acerca dos principais aspectos do desenvolvimento infantil. Como cada participante pode ter crianças em faixas etárias diferentes, as etapas de desenvolvimento abordadas são as que correspondem aos dados fornecidos pelos pais na pré testagem e na primeira sessão. Conversar sobre o desenvolvimento visa ajudar os pais a saberem o que podem e o que não podem esperar de seus filhos em uma determinada faixa etária, e também ajudar a compreender alguns de seus comportamentos e reações. Papalia, Olds e Feldman (2006) e Bee (2003) dão o embasamento dessa sessão e do material de apoio entregue aos pais (Anexo B). E, por sua linguagem de fácil entendimento, além de muitos exemplos pautados no cotidiano, os aspectos desenvolvimentais do livro ‘Eduque com Carinho' (Weber, 2005) compõe essa sessão.

Antes de o terapeuta apresentar qualquer conteúdo sobre desenvolvimento, é pedido aos pais que contem um pouco sobre a idade dos filhos e o que percebem em seus comportamentos e sentimentos nessa etapa. Quando o participante possui filhos em diferentes faixas etárias, é comum que falem sobre todos e façam comparações entre as diferentes etapas.

Após o diálogo, o terapeuta apresenta alguns conteúdos selecionados, entregando aos participantes uma folha com informações acerca de desenvolvimento, com características comportamentais, cognitivas, emocionais e maturacionais de cada uma das fases do desenvolvimento. A ideia é estimular a percepção dos pais e discussão acerca do que observam em seus filhos e quais os principais desafios que as etapas do desenvolvimento oferecem para a educação das crianças. Sugere-se que esse material seja distribuído para cada participante e que os mesmos sejam incentivados a levarem o material para casa a fim de conversarem com cônjuge ou demais participantes na educação das crianças, além de poder adotar a função de lembrete.

Após o tópico de desenvolvimento, inicia-se a segunda etapa da sessão, que visa trabalhar noções básicas de comunicação eficaz e sua importância na relação pai-filho. Para tal, é realizada uma dinâmica em que um participante voluntário recebe uma série de instruções inventadas na hora, que deve desempenhar logo em sequência (por exemplo: rode, pule três vezes em um pé só, coloque a mão esquerda na orelha e a direita no joelho esquerdo). Essas instruções são dadas pelo terapeuta em voz baixa, sem olhar nos olhos e faladas rapidamente. O participante é instruído então a executar os movimentos e logo após contar como se sentiu executando as orientações. Abre-se espaço para uma discussão de 
como conversam normalmente com seus filhos e se percebem dificuldades de comunicação ou que possam estar relacionadas.

Orientações relativas a uma comunicação eficaz e positiva são ensinadas, sobretudo ao se trabalhar a explicação de regras para crianças e fazer solicitações a elas. Alguns exemplos de orientações fornecidas são: olhar nos olhos da criança, falar em tom calmo, abaixar-se à altura da criança quando for fazer um pedido, ensinar algo ou explicar uma regra, evitar conversar quando estiver muito irritado ou bravo, dar espaço para o filho tirar dúvidas e certificar-se de que o que esta sendo dito foi compreendido por ele (Clark, 2009;Weber, 2005).

Pede-se então ao grupo que tentem melhorar a forma como o terapeuta fez os pedidos da dinâmica anterior e que utilizem as técnicas da comunicação eficaz para instruir um colega voluntário a desempenhar uma sequencia de tarefas semelhantes à anterior. Como tarefa de casa é solicitado aos participantes que prestem atenção às formas que se comunicam com as crianças em casa e coloquem em prática, ao menos uma vez, as orientações trabalhadas na sessão, observando como a criança se comporta frente à modificação do comportamento dos pais.

\section{Terceira sessão:}

Este encontro enfoca o modo como os participantes se percebem como pais. O que valorizam, como foram criados, que modelos reproduzem ao educar suas crianças e o que consideram difícil e prazeroso na função de ser pai. O inicio dessa sessão é muito pautado em diálogo e, frequentemente, muitos aspectos emocionais dos participantes aparecem nessa conversa. É explicada aos pais a base do modelo cognitivo (Beck,1997), em que pensamentos, emoções e comportamentos estão profundamente conectados. E que os pensamentos que possuem influenciar também o comportamento com seus filhos e como se sentem a respeito deles e si mesmos ao educar (Caminha, Bellé, \& Pelisoli, 2007).

Os significados e crenças que os pais atribuem a essa função e as crenças de "o que é ser pai”, “o que é necessário ensinar para meu filho”, “o que meu filho espera de mim”, "devo ser rígido", "devo ser melhor amigo", "sou modelo", que aparecem nesse encontro são fundamentais para compreender alguns aspectos cognitivos (Caminha, 2011). Estes pensamentos podem ser úteis ou disfuncionais para os participantes na hora de educar e serão retomados nas sessões seguintes ao se trabalhar o modelo cognitivo e a psicoeducação de distorções cognitivas. Além disso, auxilia no levantamento de recursos que podem ser utilizados no cotidiano familiar dos participantes. Essa etapa do encontro consiste em uma 
primeira caracterização cognitiva e emocional dos pais frente ao papel de educar e será retomada e embasará todas as sessões seguintes.

O entendimento das crenças e percepções dos pais referentes aos comportamentos de seus filhos também tem um espaço importante. De acordo com Barkley (1977) compreender o que os pais consideram que fazem as crianças agirem mal é fundamental para nortear a reestruturação e o processo de mudança.

Ao adentrar a temática do comportamento infantil, o terapeuta auxilia os participantes a compreender como as crianças podem reagir ao comportamento dos pais. Para isso, fornece ao grupo as noções básicas e leis do comportamento, mostrando que todo comportamento produz consequências e é controlado por elas e que pode ser modificado a partir da alteração de antecedentes e consequências (Moreira \& Medeiros, 2007). Para que os pais possam entender melhor os modos de agir de seus filhos e as associações entre os antecedentes e as consequências dos comportamentos dos mesmos, é ensinado a eles o funcionamento do modelo ABC de Ellis (1962).

Para checar a compreensão do modelo, o terapeuta pede aos pais exemplos de comportamentos negativos das crianças e os estimula a pensar nos antecedentes e consequentes do mesmo, além dos pensamentos que estão ligados àquela situação. É trabalhada nesse momento a forte influência que os comportamentos dos pais exercem no comportamento das crianças e como isso também pode auxiliar na modificação de comportamentos infantis indesejáveis.

Usualmente os terapeutas apresentam nessa sessão um vídeo disponível no Youtube chamando "Children see, children do", que aborda o tema do modelo adulto para as ações da criança. Logo após, é discutida a influência que os pais têm nos comportamentos infantis e, como atuam como modelo para as crianças em grande parte do tempo (Lopes \& Lopes, 2008).

Após todos os participantes terem compreendido a influência das ações dos pais para os filhos, é pedido a eles que escolham um comportamento recorrente dos filhos que desaprovem e observem ao longo da semana as consequências e antecedentes que possam estar associados a eles. É solicitado que escrevam o que perceberam, bem como o que fizeram para corrigir esse comportamento e as novas consequências dessa ação para o comportamento da criança.

\section{Quarta sessão:}

A retomada da tarefa é muito importante para o início desse encontro. É através dela que os pais compartilham as observações e anotações feitas sobre o comportamento de seus 
filhos, antecedentes, pensamentos e consequências. Possibilita também que compartilhem as interpretações que fazem do comportamento infantil, o que permite aos terapeutas conhecerem um pouco acerca de pensamentos e crenças que possuem no educar.

Nesse momento, frequentemente relatam também as estratégias para corrigir o comportamento inadequado que adotaram e compartilharem as interpretações que fazem dos comportamentos infantis. Este é o principal tema desta sessão: as práticas educativas positivas e negativas. Já de posse das noções básicas de leis do comportamento e da observação da semana, os pais tendem a estar preparados para compreender que as formas que utilizam para educar influenciam fortemente na forma como os filhos mantém ou modificam seu comportamento. É reforçado o papel dos pais como modelos e a importância de investirem tempo e afeto na educação das crianças a fim de ensiná-las a diminuir comportamentos inadequados, aumentar comportamentos desejáveis, fortalecerem seu senso de autonomia e autoeficácia, além de cuidarem para uma boa qualidade nas interações entre pais e filhos.

Uma dinâmica adaptada de Weber, et al. (2006) é proposta nessa sessão: todos os participantes, em roda, são orientados pelo terapeuta a decorarem uma sequência simples de números. Assim, cada participante diz um deles e passa a vez para o próximo. A cada rodada, os números são substituídos por palavras simples, barulhos ou ações, como bater palmas ou ficar mudo. Quem falar o número original ao invés da nova ação perde na brincadeira. Terapeuta e coterapeuta combinam anteriormente de, em uma rodada. elogiar os participantes pelo esforço, mesmo quando erram algum item, incentivando-os, e em outra rodada de criticá-los, apressá-los e desmotivá-los pelo erro.

Findada a dinâmica, terapeuta e participantes conversam sobre como se sentiram em ambas as rodadas após interferência dos terapeutas e como isso pode ter impactado seu desempenho. É explicada a importância do reforço positivo e o porquê de ser a estratégia educativa a ser mais incentivada, sendo ensinada aos pais a importância de, elogiar os bons comportamentos das crianças e ignorar os maus comportamentos, desde que não ofereçam risco à criança e aos outros, visando fortalecer comportamentos desejados e diminuir/extinguir os inadequados (Friedberg \& McClure, 2004; Marinho \& Caballo, 2002; Moreira \&Medeiros, 2007; Weber, 2005). Estratégias para quando os comportamentos não podem ser apenas ignorados e necessitam ser reduzidos ou eliminados também são ensinadas aos pais como o time-out e a retirada de recompensas (Clark, 2009; Friedberg \& McClure, 2004) quando é necessário estabelecer consequências mais rígidas para o comportamento infantil. 
Nessa sessão, o espaço final é destinado a uma breve discussão acerca da punição e dos possíveis riscos envolvidos, bem como do que é ensinado para a criança quando ela é educada com agressividade. Aspectos cognitivos e emocionais dos pais ao educar, seja com punição, seja com reforço e diálogo, são também abordados nessa sessão (Weber, Viezzer, \& Brandenburg, 2004).

Determinados grupos demandam mais tempo nesse tema, sobretudo se os participantes foram educados de modo punitivo e reproduzem esse padrão. Essas especificidades relacionadas à configuração de grupo são avaliadas a cada intervenção e, sendo necessário, um espaço da próxima sessão é destinado para a continuação da temática da punição e da substituição por práticas educativas mais positivas, como o diálogo, o reforço, ou mesmo a extinção de comportamentos inadequados.

\section{Quinta sessão:}

Após os principais aspectos comportamentais terem sido trabalhados com os pais, além de serem incentivados a treinarem a comunicação eficaz e adotarem práticas educativas mais positivas, um último aspecto comportamental de grande relevância é trabalhado com os participantes: a consistência no estabelecimento de regras e limites. O terapeuta auxilia os pais a identificarem regras e limites que são difíceis de serem estabelecidos ou seguidos pelas crianças em cada um dos casos do grupo e os ensinam algumas estratégias para que possam estabelecer limites claros e consequências adequadas para o cumprimento ou descumprimento das regras, Uma dessas estratégias, já apresentada em sessões anteriores, é o investimento em clareza, e boa comunicação. São retomados também, aspectos de desenvolvimento que possam estar influenciando no descumprimento de alguma regra (como por exemplo, pais que exigem além do que uma criança pequena é capaz de compreender e/ou executar).

Outros recursos mais concretos são exemplificados com os pais, como fazer um contrato com a criança sobre regras e consequências ou anotá-las em uma cartolina ou lousa, após terem sido previamente estabelecidas pelos pais e conversada com as crianças (Clark, 2009). A economia de fichas, uma técnica comportamental baseada em contingências que visa premiar respostas adequadas da criança (Barkley, 1997) também é um recurso que pode ser ensinado aos participantes, caso queixem-se de dificuldade persistente das crianças em seguir as regras. Para a tarefa de casa, os pais são também orientados a escolherem uma regra que querem implementar e seguirem os passos ensinados nas sessões ao longo da semana. 
Nas sessões anteriores, além dos aspectos comportamentais, algumas das crenças, pressupostos e opiniões sobre o educar, além dos sentimentos envolvidos, foram abordados no grupo, como a percepção que tem do papel que assume como pais, a interpretação do comportamento de seus filhos e de suas próprias práticas educativas. A quinta sessão visa auxiliar os pais a identificarem pensamentos e sentimentos que possam influenciá-los nas dificuldades que encontram ao educar, de acordo com o modelo cognitivo (Beck,1997).

Seguindo este modelo, é retomada com os participantes a relação entre pensamento, emoção e comportamento. Toda a apresentação pauta-se em exemplos já trazidos por eles nos outros encontros, como se sentem ao dar um castigo ao filho, ao fazer um elogio, o que pensam ao vê-lo comportando-se mal, dentre outros. A partir desses exemplos é explicado a eles o que são pensamentos automáticos e que estes podem modular o que sentem e fazem em muitas ocasiões. É ensinado a eles que os pensamentos automáticos podem ser acessados com o treino de automonitoramento. O pensamento pode modular o que sentem e o que fazem em muitas ocasiões, esse treino é inicialmente feito na sessão. O terapeuta pede então para lembrarem como se sentem em algumas situações, por exemplo, quando o filho faz algo que gostam muito ou quando se comportam mal e o "que passa em suas cabeças nesse momento", na busca de identificar pensamentos automáticos.

Exemplos anteriores trazidos pelos participantes em sessões também podem ser úteis nesse treino de identificar o que são pensamentos automáticos. Após terem compreendido e identificado alguns, o terapeuta auxilia os pais a identificarem e perceberem alguns padrões que se repetem em seus pensamentos automáticos. que podem dificultar na educação de seus filhos. Esses pensamentos que dificultam, são também chamados de disfuncionais (Knapp \& Rocha, 2003). Alguns exemplos encontrados nos grupos já realizados foram: pensar que a criança adota maus comportamentos sempre de propósito ou para irritar os pais, ou pensar que vai magoar o filho se disser não, ou ainda, que se necessitar desculpar-se com o filho ele perderá o respeito pela autoridade do pai.

Após certificar que os pais compreenderam a influência dos pensamentos sobre como se sentem e agem, a tarefa solicitada para a semana é de autopercepção: monitorar pensamentos. É orientado que devem tentar fazê-lo sempre que acontecer uma situação difícil com o filho que evoque alguma emoção desconfortável.

\section{Sexta sessão:}

A última sessão interventiva do grupo tem múltiplos objetivos: visa auxiliar aos pais a compreenderem e lidarem com pensamentos automáticos disfuncionais que possam prejudicá- 
los na educação dos filhos ou na interação com eles; ensinar as principais distorções cognitivas e busca trabalhar algumas técnicas de manejo de emoções desconfortáveis, como o relaxamento e de resolução de problemas (Feilstrecker, Hatzenberger, \& Caminha, 2003; Leahy, 2006). Inicia-se com a retomada da tarefa e diálogo entre os membros acerca da identificação de pensamentos automáticos na semana e se perceberam influência desses em seu próprio comportamento junto aos filhos.

Logo em seguida, enfocam-se as distorções cognitivas, vieses ou erros sistemáticos na forma das pessoas interpretarem suas experiências e acontecimentos (Beck, 1997; Knapp, 2004). Essas são identificadas com base na relação pai e filho. Para tal, são apresentas aos pais as distorções cognitivas mais comuns e é entregue uma lista, componente da Cartilha PROPAIS-USP: Fortalecendo laços - Lembretes de apoio (Maehara, et al., 2010), com a descrição e exemplos dessas distorções para que possam levar para casa. É pedido a eles que identifiquem as que mais aparecem no cotidiano e como podem lidar com elas, avaliando as situações com base em evidências e construindo pensamentos alternativos mais adaptativos às situações.

Abre-se espaço para dúvidas e receios dos pais acerca do modelo cognitivo e da influência das cognições nos comportamentos próprios e até dos filhos, que são dialogadas e orientadas pelo terapeuta. Por fim, algumas técnicas de manejo de ansiedade e raiva são ensinadas aos pais, para lidarem com situações mais difíceis, paralelamente com a adoção das práticas educativas adequadas e questionamento de pensamentos automáticos distorcidos, quando ocorrem. As principais técnicas trabalhadas são: a respiração diafragmática, o relaxamento muscular progressivo breve e o time-out (Leahy, 2006; Lipp \& Malagris, 2010) para situações de raiva em que os pais podem se ausentar por alguns minutos para se acalmarem e refletirem melhor, antes de agir com os filhos.

A resolução de problemas foi ensinada indiretamente aos pais ao longo de várias sessões e, na última ela é trabalhada na íntegra. Estando os participantes mais conscientes das dificuldades que enfrentam, das estratégias educativas que podem utilizar e do esforço para analisar e substituir pensamentos automáticos disfuncionais que possam atrapalhar a educação e a interação familiar, a técnica completa é ensinada e treinada com eles em grupo.

O terapeuta explica aos pais que um problema pode ter múltiplas soluções e que estas, devem ser analisadas com base no máximo de evidências disponíveis, para se escolher qual a melhor alternativa a ser adotada. Assim, o primeiro passo é descrever a situação difícil, o segundo é listar todas as possíveis soluções, posteriormente analisar uma a uma, em termos de prós e contras, escolher a mais adequada depois dessa análise, colocá-la em prática e analisar 
os resultados. Por mais que nem todas as situações difíceis que os pais possam enfrentar ao educar permitam que se tome todo o tempo de reflexão necessário pedido pela técnica de resolução de problemas, a lógica da mesma pode ser muito útil para os pequenos impasses que as dificuldades do cotidiano possam trazer.

Para que o conteúdo dessa sessão seja fixado, o terapeuta auxilia os pais a elencarem alguns exemplos e praticar, na sessão, a lógica da técnica de resolução de problemas. Ao final desse encontro, que é o último em conteúdo, terapeuta e coterapeuta combinam com os participantes um último encontro, em que será realizada avaliação final do grupo e agendado o pós-teste. Pode ser combinada também uma confraternização com os participantes, sendo o último encontro mais festivo e informal.

\section{Avaliação final e encerramento:}

O encontro de avaliação final visa coletar opiniões e sugestões dos pais acerca do grupo e do programa. Duas modalidades de avaliação podem ser adotadas: na primeira, terapeuta e coterapeuta perguntam aos pais diretamente o que acharam do grupo, pontos positivos, pontos negativos, sugestões de melhoras ou alterações, percepções sobre a duração do mesmo, se viram alguma diferença em casa com seus filhos, se perceberam algo que não foi trabalhado ao longo das sessões, etc. $O$ intuito é que os pais dêem o máximo de informação possível sobre como foi para eles participar e, coletar informações que possam ser úteis para o aprimoramento futuro do programa.

Para grupos com participantes que falam menos espontaneamente, as perguntas podem ser adaptadas na mesma estrutura da dinâmica "quebra-gelo" inicial: colocadas em vários papéis dentro de uma caixinha, em que cada participante retira um e responde a pergunta que sortear, sendo realizadas algumas rodadas para que a coleta dessas informações qualitativa possa ser concretizada.

Posteriormente é agendado o pós-teste, que pode ser feito no mesmo dia, mas de forma individual, aplicados pelo terapeuta e pelo coterapeuta, sendo reaplicados os instrumentos da pré testagem. É entregue também a cartilha "PROPAIS-USP: Fortalecendo laços - Lembretes de apoio" (Maehara, et al., 2010) com dicas e retomadas de temas trabalhados ao longo das seis sessões.

Além da cartilha uma mensagem de agradecimento e incentivo pode ser oferecia aos

pais. É reforçado com eles também que, se necessitarem de algum auxílio ou tiverem alguma dúvida, podem entrar em contato com a equipe de orientação de pais do LaPICC-USP 
(estagiários terapeutas, pesquisadora responsável e professora coordenadora do Laboratório) conforme especificado no termo de consentimento assinado por eles antes do início da intervenção. Pode ser combinada também uma confraternização com os participantes após a pós testagem para festejar a conclusão do programa.

\subsection{Aspectos éticos.}

$\mathrm{O}$ projeto foi submetido à apreciação do Comitê de Ética em Pesquisa com Seres Humanos da Faculdade de Filosofia, Ciências e Letras de Ribeirão Preto - USP. A pesquisa iniciou-se efetivamente apenas após sua aprovação (Número de Protocolo: CAAE02199712500005407).

Ressalta-se que os cuidados relativos à utilização de instrumentos de coleta de dados e de documentação dos respectivos protocolos foram assegurados, conforme princípios éticos e legais do Conselho Federal de Psicologia (CFP). Após o aceite feito pelo Comitê de Ética em Pesquisa da Faculdade de Filosofia, Ciências e Letras de Ribeirão Preto (Anexo C), foi marcado junto à coordenação de cada uma das instituições uma reunião geral com os pais, agendada pela diretoria da escola para explicação do grupo e convite de participação.

Todos participantes preencheram o Termo de Consentimento Livre e Esclarecido (TCLE) (Anexo D) e o Termo de Compromisso de Utilização de Dados (TCUD) (Anexo E) conforme as exigências do mesmo Comitê de Ética. Foi assegurado aos pais, a possibilidade de interromper a participação em qualquer momento, caso desejasse e disponibilizado a eles a possibilidade de conversar com os estagiários de psicologia e/ou com a pesquisadora responsável pelo estudo, caso tivessem alguma dúvida ou demanda despertada pela intervenção.

A pesquisa destinou-se à população não clínica, mas sendo observado na pré testagem características clínicas ou possibilidade de sofrimento significativo dos pais ou de seus filhos, uma reunião individual seria marcada com os pais. Nessa, seria oferecida possibilidade de apoio psicológico, através de encaminhamento gratuito, tanto na Universidade de São Paulo como em outros serviços de saúde disponíveis no município.

\subsection{Delineamento.}

A pesquisa caracteriza-se com um estudo exploratório e interventivo e utiliza-se de metodologia de análise quantitativa e qualitativa. Enquadra-se em um delineamento quase 
experimental, com aplicação das medidas de avaliação pré e pós-teste a intervenção em grupos.

As avaliações quantitativas foram feitas intragrupos e intergrupos, para comparação de igualdades e diferenças entre as condições iniciais dos participantes. As avaliações qualitativas foram feitas a partir dos relatos dos participantes ao longo das sessões.

\subsection{Participantes.}

Foram convidados para esse estudo 45 pais ou cuidadores de crianças com pelo menos um filho, com idade entre 6 e 12 anos. Para inclusão dos participantes, era necessário que os filhos estivessem matriculados e frequentando regularmente a escola. Apenas 25 pais concluíram sua participação, comparecendo a pelo menos 75\% das sessões do PROPAIS II. Os outros pais abandonaram a participação após a pré-testagem ou no máximo, após a primeira sessão interventiva, passando a atuar como grupo de comparação.

Os participantes que concluíram a intervenção tinham entre 26 e 60 anos, com média de 35.6 anos e desvio padrão de 8.2. Os participantes do grupo de comparação tinham entre 22 e 60 anos, com média de 33.5 anos e desvio padrão de 8.9 .

O programa PROPAIS II foi aplicado em 2012 e 2013 nas duas instituições identificadas como: Núcleo de Fortalecimento de Vínculos (Instituição I) e Centro Educacional Infantil (Instituição II). A parceria com a Instituição I para a realização do estudo foi realizada anteriormente e, portanto, mais grupos foram realizados em suas dependências, totalizando quatro. A Instituição II, cuja parceria foi firmada apenas em 2013 recebeu dois grupos.

No total foram realizados seis grupos de orientação de pais ao logo do estudo. As informações de cada grupo: identificação, localização, número e nome fictício dos participantes (Anexo F).

Três filhos dos participantes do grupo seis tinham cinco anos no pré-teste, mas completaram seis até a pós-testagem, portanto foram incluídos na amostra. Todas as crianças desse último grupo frequentavam o último ano da educação infantil, enquanto as dos outros grupos já estavam no ensino fundamental. As últimas turmas do ensino infantil foram inseridas na pesquisa após solicitação da instituição II e considerações do LaPICC-USP. Foi decidido pela incorporação, mas apenas os pais de crianças próximas a completar seis anos foram incluídos nesse estudo, devido aos requisitos dos instrumentos de mensuração. 


\subsection{Instrumentos.}

Os instrumentos e medidas de avaliação utilizados nesse estudo foram:

- Escalas de Qualidade na Interação Familiar (EQIF - versão pais), (Weber, et al., 2003): Instrumento que visa avaliar as práticas educativas e a interação entre pais e filhos, na percepção dos pais. É composta por sete subescalas que avaliam práticas educativas parentais positivas: Relacionamento afetivo, Envolvimento, Regras e Monitoria, Comunicação Positiva dos filhos, Modelo Parental, Clima Conjugal Positivo, e Sentimento dos filhos. E três subescalas que avaliam práticas negativas: Punição Corporal, Comunicação Negativa, Clima Conjugal Negativo.

No total, são 52 questões em sistema Likert de cinco pontos (nunca, quase nunca, às vezes, quase sempre, sempre). Os escores podem ser avaliados no total, somando a pontuação de todas as subescalas, ou separadamente, por cada uma delas.

Essa versão da EQIF foi originada a partir do instrumento original EQIF-versão filhos (Weber, Prabop, Salvador, \& Brandenburg, 2008; Weber, Salvador, \& Brandenburg, 2009). Em sua versão para pais, o instrumento apresenta uso apenas clínico, pois sua validação ainda não foi concluída, sendo publicado no livro programa de Qualidade na Interação Familiar (Weber et al., 2006) como mensurador de aproveitamento e percepção de efeito de programas de orientação de pais.

A escolha por uma mensuração apenas clínica, apesar de todas as limitações que oferece às pesquisas, embasou-se em dois motivos: primeiramente, à escassez de instrumentos que avaliem a interação familiar e as práticas educativas na percepção dos próprios pais. Em segundo lugar, pela dificuldade que as crianças do contexto da pesquisa apresentaram, em um estudo piloto (não publicado) desse projeto, em responder instrumentos sobre si próprios e sobre seus pais, em compreender e preencher o protocolo, mesmo com auxílio de aplicadores treinados.

Essa dificuldade inviabilizou que fossem utilizados protocolos de avaliação das percepções infantis sobre a interação familiar e práticas educativas dos pais, sendo necessário buscar alternativas para que os próprios pais se avaliassem. Foi necessário também adotar uma variável que permitisse modificação no curto período interventivo, optando-se pelas práticas educativas parentais em detrimento dos estilos parentais. 
- Child Behavior Checklist (CBCL/ 6-18) (Achenbach \& Rescorla, 2001): Busca mensurar a competência social e problemas comportamentais das crianças e adolescentes de 6 a 18 anos, a partir do ponto de vista dos pais ou responsáveis. O CBCL é composto por duas partes: a primeira avalia a competência social e os outros possíveis problemas de comportamento. Inclui 20 itens pontuados em escala Likert de zero a quatro. Os itens sobre competência social fornecem escores para três escalas específicas: Atividades, sociais e escolares, e uma escala geral de competência social Total. A seção de competência social avalia: o envolvimento das crianças em atividades; quão bem eles realizam trabalhos ou tarefas; os padrões de interação social e o desempenho escolar. Esta seção também investiga doença e invalidez, as principais preocupações e os aspectos positivos observados pelos pais sobre a criança/adolescente.

A segunda seção é a de perfil de comportamento, ela é composta por 118 itens que podem ser marcados como zero (não é verdade), um (um pouco ou às vezes verdadeiro) ou dois (muito verdadeiro ou frequentemente verdadeiro). Esses itens fornecem pontuações para oito escalas específicas de síndromes: ansiedade/depressão; retraimento/ depressão; queixas somáticas; problemas sociais; problemas de pensamento; problemas de atenção; comportamento de quebra de regras e comportamento agressivo.

Apresenta também três escalas gerais: problemas de comportamento internalizantes, problemas de comportamento externalizantes e total de problemas de comportamento. A escala de problemas de comportamentos internalizantes corresponde às subescalas: ansiedade / depressão, retraimento / depressão e queixas somáticas. As demais, compõem a escala de problemas de comportamentos externalizantes e a soma de ambas compõem a escala total de problemas.

Os escores brutos de todas as escalas são dados pelas somas das classificações $(0,1 \mathrm{e}$ 2) de cada item respondido e transformados em Escores-T, com base em dados normativos. Os escores $\mathrm{T}$ do teste permitem a categorização das crianças como clínicas, limítrofes e não clínicas.

O CBCL/6-18, (versão original em Inglês) tem boa confiabilidade teste-reteste e consistência interna, sendo a média dessa para as escalas de competência e para as síndromes com base empírica 0,90. A consistência interna das escalas de problemas, medida por alpha de Cronbach variou 0,72-0,97. No Brasil, foi realizado um estudo de validação preliminar do CBCL ( Bordin et al., 2013; Bordin, Mari, \& Caeiro, 1995) e adaptações após a publicação do novo manual CBCL 6/18. (Bordin et al., 2013; Bordin et al., 1995) Foi encontrado um alto índice de correlação entre as duas avaliações, o que sugere que o uso do questionário é válido 
no Brasil. Atualmente o protocolo oficial brasileiro do CBCL 6/18 foi elaborado em 2010 ${ }^{1}$. Este instrumento corresponde à última versão inglesa do CBCL/6-18. ${ }^{2}$

- Critério de Classificação Econômica Brasil (CCBE), (Associação Brasileira de Empresas de Pesquisa, 2011): é um instrumento de segmentação econômica que utiliza o levantamento de características domiciliares, pela presença e quantidade de alguns itens de conforto e grau escolaridade do chefe de família, para diferenciar a população. O instrumento atribui pontos em função de cada característica domiciliar e realiza a soma destes pontos. É feita então uma correspondência entre faixas de pontuação e os estratos de classificação econômica definidos por A1 (30 a 34 pontos), A2 (25 a 29 pontos), B1 (21 a 24 pontos), B2 (17 a 20 pontos), $\mathrm{C}$ (11 a 16 pontos), $\mathrm{D}$ (6 a 10 pontos) $\mathrm{E}$ ( 0 a 5 pontos).

- Ficha de identificação: Preenchida pelos terapeutas na primeira sessão interventiva, consta de nome, idade e ocupação do participante, número e sexo dos filhos e principal problema que encontram na educação das crianças. (Anexo $G$ )

- Folha de registo: Material utilizado pelo observador das sessões para registrar falas dos participantes, condução dos terapeutas e acontecimentos durante o grupo. (Anexo $\mathrm{H}$ )

\subsection{Procedimentos.}

\subsubsection{Implementação, coleta e armazenamento dos dados.}

Os procedimentos em ambas as instituições foram muito semelhantes e são aqui relatados de maneira geral, apesar de terem sido realizados separadamente. A equipe que ofereceu cada um dos grupos era composta por um terapeuta, um coterapeuta e um observador, os dois primeiros estagiários dos dois últimos anos de psicologia e o observador aluno de terceiro ano.

Terapeuta e coterapeuta coordenavam os grupos e o observador era responsável por registrar as falas dos participantes ao longo das sessões e as intervenções realizadas pelos terapeutas. Cada trio de terapeuta, coterapeuta e observador recebeu o mesmo treinamento para atuar junto aos grupos e, cada tríade realizou dois grupos interventivos. No total, a equipe foi alterada três vezes, assegurando-se de que o treinamento, acompanhamento de supervisão e o nível de preparo atuação fosse o mesmo, o que foi certificado por duas psicólogas supervisoras.

\footnotetext{
${ }^{1}$ Número de licença na Universidade de Vermont: 207-12-04-06, 2010.

${ }^{2}$ Copyright 2001 T. Achenbach ASEBA, da Universidade de Vermont, 1 South Prospect St ., Burlington, VT 05401-3
} 
Em ambas as instituições que receberam o PROPAIS II a participação dos pais foi voluntária e deu-se mediante a manifestação de interesse dos mesmos após divulgação da proposta de trabalho nas reuniões de pais previamente estabelecidas pela coordenação pedagógica. Foram oferecidos dois grupos interventivos por semestre, mas apenas os primeiros grupos de cada semestre tiveram adesão suficiente para que o programa fosse aplicado, ou seja: adesão maior que dois participantes de famílias diversas.

A alocação dos participantes nos grupos foi feita mediante aceite e disponibilidade dos pais para frequentarem as seis sessões interventivas e as testagens, sendo convidados novos pais, a cada semestre, na reunião de pais regular das instituições. Foi assegurado a todos os participantes que poderiam desistir da participação em qualquer momento da pesquisa. No entanto, o recrutamento de novos participantes para ocupar a vaga em caso de desistência, só poderia ser feito até o início da segunda sessão de intervenção, para assegurar a apreensão e continuidade dos conteúdos enfocados no programa.

Para cada grupo, foi realizado um primeiro contato com a coordenação pedagógica e diretoria das instituições foi feito, sendo apresentada a proposta do grupo e o programa interventivo na íntegra. Nessa reunião participaram coordenadores, diretores, a pesquisadora responsável e os dois estagiários de psicologia que coordenaram os grupos diretamente. $\mathrm{Na}$ Instituição II, a psicóloga contratada também participou, sendo que esta acompanhou as supervisões clínicas oferecidas aos estagiários pela pesquisadora responsável durante o primeiro grupo realizado. Após as coordenações manifestarem interesse pela implantação do programa, foi agendada uma reunião com os pais de crianças entre 6 e 12 anos, idade assistida por ambas às instituições, para apresentação da proposta e convite de participação.

$\mathrm{Na}$ Instituição I foram chamados à cada reunião cerca de 50 pais selecionados aleatoriamente pela coordenação pedagógica, dos quais aproximadamente 30 compareceram à reunião inicial. Apesar de mais da metade dos participantes terem manifestado interesse em participar, apenas uma média de cinco pais participaram efetivamente nos grupos.

Já na II, foram convidados todos os pais de crianças nessa faixa etária que participavam de um projeto de atividades culturais e sociais oferecidas pela instituição, totalizando 25 convites. Dez pais compareceram a pré-testagem e cinco se mantiveram no grupo. O critério de inclusão para participação era ter pelo menos um filho nessa faixa etária, que estivessem estudando e que não estivessem participando concomitantemente de nenhuma outra atividade interventiva do LAPICC-USP, para controlar as possíveis interferências de duas intervenções conjuntas. 
Os pais que manifestaram interesse em participar receberam o Termo de Consentimento Livre e Esclarecido (TCLE) e o Termo de Compromisso de Uso de Dados (TCUD) e foi agendada uma reunião para realização do pré-teste. Esse foi aplicado nos pais em um mesmo dia, mas orientados separadamente por cada um dos estagiários, assim toda a testagem ocorreu de forma individual. Para os instrumentos EQIF e CBCL foi orientado aos pais, em caso de terem mais de um filho, responderem sobre aquele que percebiam maiores dificuldades no educar.

A primeira sessão do grupo iniciou-se na semana seguinte à testagem, sendo cada encontro realizado com espaçamento semanal, ao final de cada sessão era oferecido um lanche aos pais, na busca de integrá-los melhor através de um ambiente mais informal. Após as seis sessões do programa, agendava-se a última reunião, em que era feita a avaliação final em grupo e o pós-teste.

Após cada etapa de testagem, os testes foram corrigidos pela pesquisadora responsável, com auxilio do programa Excel e do Software Assessment Data Manager (ADM 7.0) do CBCL. Os dados foram armazenados em um banco de dados em computador e os testes preenchidos em papel foram armazenados em um banco de dados no LaPICC-USP. Na busca de facilitar a adesão dos pais, os coordenadores pedagógicos em conjunto com os estagiários enviavam semanalmente aos pais bilhetes para lembrar o dia e horário da sessão e eram realizados também lembretes por telefone.

Ao final de cada um dos seis grupos, foi realizada uma reunião de equipe em que estavam presentes direção e /ou coordenação das instituições e pesquisadora responsável para devolutiva do número de participantes e evolução percebida no decorrer do grupo, sendo respeitado o sigilo contratado na sessão de testagem com os participantes.

Dois meses após o primeiro grupo ter sido concluído, foi realizado contato com os pais para uma nova avaliação, na tentativa de acompanhar os efeitos do programa. No entanto, dos cinco pais participantes, apenas um tinha disponibilidade para retornar à instituição para uma nova testagem. Dos outros, dois haviam se mudado, um não pôde por motivos pessoais não relatados e com um, não foi possível restabelecer contato telefônico. Assim, esse estudo não contou com avaliações de follow-up.

\section{Resultados}

Os dados oriundos dos instrumentos de medidas e da ficha de identificação foram inicialmente agrupados para realização da caracterização da amostra. 
Os escores obtidos pré e pós-testagem dos instrumentos EQIF e CBCL foram analisados quantitativamente, com tratamento estatístico não paramétrico, com auxílio do Statistical Package for Social Sciencies (SPSS), versão 16.0 (Nie, Aull, \& Bent, 2003). O intervalo de confiança adotado em todo o estudo foi de $95 \%$.

As falas dos participantes ao longo das sessões, registrados pelos observadores dos grupos, foram analisadas com base em uma livre adaptação na Análise de Conteúdo (Bardin, 1977), a qual configura-se como um conjunto de técnicas de análise das comunicações, através de procedimentos sistemáticos e objetivos de descrição do conteúdo das mensagens. A intenção dessa forma de análise é que se possa inferir conhecimentos relativos ao modo como tais mensagens foram produzidas, transmitidas e recebidas (Bardin, 2011; Campos, 2004).

Para a realização dessa análise, as falas dos participantes anotadas nos protocolos foram examinadas e, posteriormente agrupadas em categorias de acordo com suas semelhanças. Não foram registradas todas as verbalizações dos participantes em todas as sessões, apenas as impressões, experiências e dúvidas e opiniões que traziam ao grupo e aos terapeutas, no decorrer da intervenção.

Os resultados serão apresentados a seguir separadamente. Iniciam-se com a caracterização da amostra, seguida pelas análises quantitativas para cada um dos instrumentos, sendo finalizados com as análises qualitativas dos relatos dos participantes.

\subsection{Caracterização da amostra.}

Por meio da aplicação do questionário socioeconômico, do perfil sociodemográfico do instrumento CBCL e da ficha de identificação, foram levantadas informações que possibilitaram uma caracterização da família e, mais particularmente, do adulto responsável pela criança. Essa classificação contou também com o levantamento de algumas percepções de queixas do comportamento do filho eleito para o preenchimento dos instrumentos. A caracterização foi realizada tanto para os pais que receberam o programa, que foram denominados em conjunto como "grupo interventivo", quanto para os que desistiram após a testagem, aqui denominados "grupo de desistentes". 


\subsubsection{Caracterização do grupo interventivo.}

Compuseram esse grupo 25 participantes, com idade média de 37.37 anos (DP=8.5) e seus filhos com idade média de 9.05 anos ( $\mathrm{DP}=1.9)$. Quanto ao sexo do filho, $56 \%(\mathrm{n}=14)$ do total de crianças eram meninas. A participação maior foi de mães, correspondendo a $80 \%$ da amostra $(n=20)$, seguida por avós $(12 \%, n=3)$ e pais $(8 \% n=2)$

Relativo ao estado civil a categoria predominante foi "casado/em união consensual" $(80 \%, n=20)$ para o total da amostra. Quanto às demais categorias, houve apenas um participante solteiro, e quatro participantes divorciados/separados. O número de filhos ou crianças sob responsabilidade de cada participante foi: um filho $(24 \%, \mathrm{n}=6)$, três filhos $(24 \%$, $n=6)$, dois filhos a $48 \%$ da amostra $(n=12)$ e quatro filhos a $4 \%(n=1)$.

O nível socioeconômico (NSE) das famílias concentrou-se nas categorias C (36\%, $\mathrm{n}=9)$, B2 e D (28\%, $\mathrm{n}=7$ em cada) e a categorias B1 teve $8 \%$ dos participantes $(\mathrm{n}=2)$. em cada). A categoria D foi encontrada apenas nos grupos 4 e 6 , os únicos realizados na Instituição II. Em relação às características de estrutura familiar $84 \%$ dos participantes $(\mathrm{n}=21)$ possuíam família nuclear, $8 \%(\mathrm{n}=2)$ tinham famílias recompostas (padrasto/madrasta e meios-irmãos) e também $8 \%(\mathrm{n}=2)$ das famílias eram chefiadas pelos avós, convivendo filhos e netos em uma mesma residência.

Para finalização da caracterização do perfil da amostra, as queixas principais apresentadas pelos participantes durante o pré-teste foram desobediência e teimosia. Todas as queixas apresentadas estão descritas na tabela a seguir, para os seis grupos em conjunto: 


\section{TABELA 1}

Porcentagem das Queixas Principais e Frequência de Ocorrência nos Seis Grupos Interventivos.

\begin{tabular}{cc}
\hline Queixas & Ocorrência \\
\hline Desobediência & $29.6(\mathrm{n}=8)$ \\
Teimosia & $29.6(\mathrm{n}=8)$ \\
Falta de limites & $3.7(\mathrm{n}=1)$ \\
Agitação & $3.7(\mathrm{n}=1)$ \\
Manejo do divórcio dos pais & $3.7(\mathrm{n}=1)$ \\
Um pouco atirada & $3.7(\mathrm{n}=1)$ \\
Falta de vontade & $3.7(\mathrm{n}=1)$ \\
Dependência & $3.7(\mathrm{n}=1)$ \\
Briga entre irmãos & $7.4(\mathrm{n}=2)$ \\
Falhas de comunicação & $3.7(\mathrm{n}=1)$ \\
Má educação & $3.7(\mathrm{n}=1)$ \\
Timidez & $3.7(\mathrm{n}=1)$ \\
\hline As queixas "má educação", "falta de limites”, "agitação" e "falta de vontade”
\end{tabular}

apareceram em mais de uma vez. No entanto não foram referidas como as queixas principais no momento da pré-testagem, sendo relatadas pelos participantes apenas durante as sessões, não constando repetidamente na tabela.

\subsubsection{Caracterização dos participantes desistentes.}

A caracterização dos participantes desistentes será feita em conjunto, para todos os participantes que preencheram o pré-teste e abandonaram o estudo após a testagem ou após a primeira a sessão interventiva. O agrupamento de desistentes contou com 20 participantes, desses $85 \%(n=17)$ eram mães e houve $5 \%$ da participação de pai, avó e tia ( $\mathrm{n}=3$ para cada). A maioria dos participantes era casada ou estavam em união consensual, totalizando $85 \%$ da amostra $(n=17)$, houve duas participantes divorciadas, correspondendo $10 \%$ da amostra e uma participante solteira, correspondendo a $5 \%$ da mesma.

A idade média dos participantes desse grupo foi 35.6 ( $\mathrm{DP}=8.2)$. A idade das crianças, a média foi de 8.85 anos $(\mathrm{DP}=2.54)$ e $55 \%(\mathrm{n}=11)$ delas eram meninas. O nível sócio econômico com maior ocorrência foi o $\mathrm{D}(35 \%, \mathrm{n}=7)$, seguido pelos $\mathrm{C}(30 \%, \mathrm{n}=6), \mathrm{B} 2$ (20\%, $\mathrm{n}=4)$ e $\mathrm{B} 1(15 \%, \mathrm{n}=3)$.

Informações sobre o número de filhos e queixa principal não foram informadas para a maioria dos participantes, pois a desistência antes da primeira sessão interventiva impossibilitou que tais dados fossem coletados através da Ficha de Identificação. 


\subsection{Práticas educativas parentais e qualidade de interação familiar.}

Para avaliar essas variáveis foi realizada a análise dos dados do instrumento EQIF. Inicialmente foi calculado o coeficiente Alfa de Cronbach $(\alpha)$ das Escalas de Qualidade na Interação Familiar.

\section{TABELA 2}

Análise do Coeficiente Alpha de Cronbach das Escalas de Qualidde na Interação Familiar.

\begin{tabular}{cccc}
\hline Média (DP) & Variância & Número de itens & Alpha de Cronbach \\
\hline $1.96(13.69)$ & 187.34 & 51 & 0.756 \\
\hline
\end{tabular}

O coeficiente encontrado foi de 0.756 , o valor obtido sugere boa confiabilidade das Escalas de Qualidade na Interação Familiar.

\subsubsection{Análises intergrupos.}

Antes de realizar a comparação entre os participantes que concluíram a intervenção e os que abandonaram a pesquisa, foi necessário verificar se os participantes dos seis grupos oferecidos eram semelhantes ou diferiam entre si antes da aplicação do programa. Para analisar os dados de práticas educativas parentais e interação familiar coletados no pré-teste através da EQIF, foi utilizado o teste não paramétrico Kruskal-Wallis. A análise acusou diferença no pré-teste na categoria Punição corporal (Kruskal-Wallis, p=0.02). Para identificar entre quais grupos essa diferença se encontrava, foi realizado o pós-teste de Dunn, no entanto, este não verificou diferenças estatísticas. Após o teste ter descartado a diferença na categoria Punição Corporal os seis grupos passaram a ser tratados como um único, constituindo o denominado "grupo interventivo".

Para os 20 participantes que desistiram ao longo dos seis grupos realizados, o mesmo procedimento de análise foi concretizado. O teste Kruskal-Wallis também não verificou diferença entre os participantes ( $\mathrm{p}>0.06)$, justificando o agrupamento de todos esses participantes em um único grupo. 


\subsubsection{Grupo interventivo e grupo de desistentes.}

$\mathrm{Na}$ busca de identificar diferenças entre as práticas educativas dos participantes que desistiram e os que concluíram a intervenção, foi realizada a comparação entre esses dois grupos no momento do pré-teste. Para tal foi utilizado o teste não paramétrico de MannWhitney, analisando os escores de ambos os grupos no instrumento EQIF.

O teste não acusou nenhuma diferença estatística entre os grupos (Mann-Whitney, p>0.06). Após a verificação de igualdade entre os grupos em todas as variáveis, as demais análises foram estabelecidas apenas para os participantes que concluíram a intervenção.

\subsubsection{Análises intragrupos.}

Após as análises intergrupos terem descartado diferenças estatísticas anteriormente à intervenção, foi realizada a comparação entre os escores do pré-teste e do pós-teste da EQIF para os 25 participantes que receberam o programa. Para tal foi utilizado o teste não paramétrico de Wilcoxon.

As diferenças encontradas são apresentadas na tabela a seguir: 


\section{TABELA 3}

Comparação entre Escores do Pré-teste e do Pós-teste para as Escalas de Qualidade na Interação Familiar

\begin{tabular}{cccc}
\hline & Pré-teste & Pós-teste & Comparação \\
\hline Variável & Média (DP) & Média (DP) & $p$ \\
Relacionamento afetivo & $30.12(4.50)$ & $37.56(2.41)$ & $0.00^{*}$ \\
Envolvimento & $36.12(3.57)$ & $37.76(2.18)$ & $0.01^{*}$ \\
Regras e Monitoria & $27.52(2.12)$ & $28.80(1.70)$ & $0.01^{*}$ \\
Punição Corporal & $10.16(2.83)$ & $7.84(0.99)$ & $0.00^{*}$ \\
Comunicação Positiva & $10.60(2.18)$ & $12.64(2.32)$ & $0.00^{*}$ \\
Comunicação Negativa & $11.28(2.50)$ & $9.48(2.65)$ & $0.01^{*}$ \\
Clima Conjugal Positivo & $15.44(5.77)$ & $16.44(8.30)$ & 0.24 \\
Clima Conjugal Negativo & $11.16(3.64)$ & $7.08(3.69)$ & $0.00^{*}$ \\
Modelo & $12.00(2.02)$ & $13.16(1.67)$ & $0.03^{*}$ \\
Sentimento dos filhos & $26.16(2.69)$ & $27.16(2.19)$ & $0.02^{*}$ \\
Escore Total & $1.25 \mathrm{E} 2(13.73)$ & $1.49 \mathrm{E} 2$ & $(14.41)$ \\
\hline
\end{tabular}

$* p<0.05$

Diferenças estatísticas foram encontradas no Escore Total da EQIF ( $p=0.00)$ e na maioria das subescalas $(\mathrm{p}<0.03)$. As subescalas que avaliam práticas positivas: Relacionamento Afetivo, Envolvimento, Regras e Monitoria, Comunicação Positiva, Modelo e Sentimento dos Filhos apresentaram aumento do escore pós-intervenção. As que expressam práticas negativas: Punição Corporal, Comunicação Negativa e Clima Conjugal Negativo mostram decréscimo no pós-teste. Apenas não foi encontrada diferença estatística na comparação pré e pós-teste da subescala Clima Conjugal Positivo, que avalia a boa interação entre cônjuges, tais como elogios, manifestações de afeto e comunicação adequada.

\subsection{Problemas de comportamento infantil.}

\subsubsection{Grupo interventivo e grupo de desistentes.}

Os problemas comportamentais das crianças, com base na percepção dos pais, foram avaliados através do instrumento CBCL. Para a realização de todas as análises desse 
instrumento, os resultados brutos foram inicialmente convertidos em T-Escores através da utilização do Software Assessment Data Manager (ADM 7.0) de acordo com as padronizações desenvolvidas para a análise de dados do CBCL.

Idêntico ao procedimento adotado para avaliar as práticas parentais e interações familiares, foi necessário verificar se os participantes dos seis grupos que concluíram a intervenção poderiam ser unidos em um mesmo grupo. O teste Kruskal-Wallis não verificou diferença estatística entre os participantes oriundos dos seis grupos realizados (KruskalWallis, $\mathrm{p}>0.24$ ), dessa forma os participantes foram tratados como semelhantes, compondo o grupo interventivo. Para os participantes que desistiram da intervenção, o teste Kruskal-Wallis também não verificou diferenças estatísticas $(p>0.07)$ e esses participantes também foram alocados em conjunto no grupo de comparação.

O teste de Mann-Whitney foi utilizado para analisar se o grupo de interventivo e o grupo de comparação apresentavam diferenças acerca da percepção de problemas comportamentais das crianças no pós-teste. Nenhuma diferença estatística foi encontrada (Mann-Whitney, $\mathrm{p}>0.68$ ).

\subsubsection{Análise intragrupos.}

Após nenhuma diferença ser encontrada entre os grupos interventivos e de comparação, foram realizadas análises intragrupos, comparando os escores do pós-teste e do pré-teste dos participantes que concluíram o programa. Para essa análise foi utilizado o teste Wilcoxon para cada uma das variáveis do instrumento. A média dos escores nos dois momentos de testagem e encontram-se na tabela seguinte: 


\section{TABELA 4}

Comparação pelo Teste de Wilcoxon entre Pré-teste e Pós-teste para as Variáveis do Instrumento $C B C L$

\begin{tabular}{|c|c|c|c|}
\hline & Pré-teste & Pós-teste & Comparação \\
\hline Variável & Média (DP) & Média (DP) & $\mathrm{P}$ \\
\hline Atividade & $36.07(7.35)$ & $37.60(6.84)$ & 0.22 \\
\hline Social & $42.64(9.26)$ & $42.96(11.02)$ & 0.76 \\
\hline Escola & $41.80(8.39)$ & $43.25(9.14)$ & 0.53 \\
\hline Competência total & $36.57(12.95)$ & $36.55(8.64)$ & 0.66 \\
\hline Ansiedade/Depressão & $61.84(10.02)$ & $58.36(8.03)$ & 0.10 \\
\hline Retraimento & $60.68(8.24)$ & $59.68(7.47)$ & 0.49 \\
\hline Queixas somáticas & $59.92(8.82)$ & $57.24(7.70)$ & 0.13 \\
\hline Problemas sociais & $59.80(7.65)$ & $58.40(5.64)$ & 0.45 \\
\hline Problemas pensamento & $58.80(9.35)$ & $56.60(9.03)$ & 0.20 \\
\hline Problemas atenção & $60.80(11.22)$ & $60.08(12.12)$ & 0.48 \\
\hline Problemas regras & $58.00(6.95)$ & $57.96(6.94)$ & 0.73 \\
\hline Comportamento agressivo & $64.04(10.22)$ & $59.28(10.16)$ & $0.02 *$ \\
\hline Problemas internalizantes & $61.60(11.07)$ & $58.44(8.64)$ & 0.15 \\
\hline Problemas externalizantes & $61.96(8.74)$ & $58.84(9.91)$ & $0.04 *$ \\
\hline Total de problemas & $62.68(9.46)$ & $58.84(9.91)$ & 0.11 \\
\hline Problemas afetivos & $63.32(7.15)$ & $61.20(8.44)$ & 0.13 \\
\hline Problemas ansiedade & $60.52(9.08)$ & $58.40(6.79)$ & 0.25 \\
\hline Problemas somáticos & $58.32(9.71)$ & $59.60(9.90)$ & 0.21 \\
\hline Atenção/Hiperatividade & $62.24(9.03)$ & $57.76(7.38)$ & 0.21 \\
\hline Desafiador opositivo & $60.40(7.18)$ & $57.84(6.24)$ & 0.06 \\
\hline Problemas conduta & $60.00(8.46)$ & $54.20(6.48)$ & 0.21 \\
\hline Tempo cognitivo lento & $55.60(6.97)$ & $55.60(13.97)$ & 0.49 \\
\hline Problemas obsessivos & $59.96(10.56)$ & $58.48(8.30)$ & 0.18 \\
\hline Estresse pós-traumático & $61.80(9.49)$ & $36.55(8.64)$ & 0.14 \\
\hline
\end{tabular}

Foram encontradas diferenças estatísticas nas variáveis: comportamento agressivo $(\mathrm{p}=0.02)$ e problemas externalizantes $(\mathrm{p}=0.04)$ existindo diminuição do escore no pós-teste.

Para o instrumento CBCL foi verificada também a magnitude de efeito do tratamento (Cohen, 1988), através da comparação entre os dois momentos de testagem, visando analisar a 
significância clínica dos resultados (Jacobson \& Truax, 1991; Kendall, 1999). De acordo com Cohen (1988), a magnitude do efeito pode ser próxima a $0.2,0.5$ e 0.8 , classificadas como pequena, média e grande, respectivamente. As variáveis desse estudo apresentaram as seguintes magnitudes de efeito:

\section{TABELA 5}

Magnitude do Efeito de Cohen para as Variáveis de Problemas de Comportamento Infantil, Mensuradas pelo $C B C L$

\begin{tabular}{|c|c|c|c|}
\hline & Pré-teste & Pós-teste & $\begin{array}{l}\text { Magnitude } \\
\text { do efeito }\end{array}$ \\
\hline Variável & Média (DP) & Média (DP) & $E S$ \\
\hline Atividade & $36.07(7.35)$ & $37.60(6.84)$ & 0.16 \\
\hline Social & $42.64(9.26)$ & $42.96(11.02)$ & 0.11 \\
\hline Escola & $41.80(8.39)$ & $43.25(9.14)$ & 0.11 \\
\hline Competência total & $36.57(12.95)$ & $36.55(8.64)$ & 0.00 \\
\hline Ansiedade/Depressão & $61.84(10.02)$ & $58.36(8.03)$ & 0.26 \\
\hline Retraimento & $60.68(8.24)$ & $59.68(7.47)$ & 0.08 \\
\hline Queixas somáticas & $59.92(8.82)$ & $57.24(7.70)$ & 0.22 \\
\hline Problemas sociais & $59.80(7.65)$ & $58.40(5.64)$ & 0.13 \\
\hline Problemas pensamento & $58.80(9.35)$ & $56.60(9.03)$ & 0.16 \\
\hline Problemas atenção & $60.80(11.22)$ & $60.08(12.12)$ & 0.04 \\
\hline Problemas regras & $58.00(6.95)$ & $57.96(6.94)$ & 0.00 \\
\hline Comportamento agressivo & $64.04(10.22)$ & $59.28(10.16)$ & 0.33 \\
\hline Problemas internalizantes & $61.60(11.07)$ & $58.44(8.64)$ & 0.21 \\
\hline Problemas externalizantes & $61.96(8.74)$ & $58.84(9.91)$ & 0.27 \\
\hline Total de problemas & $62.68(9.46)$ & $58.84(9.91)$ & 0.27 \\
\hline Problemas afetivos & $63.32(7.15)$ & $61.20(8.44)$ & 0.18 \\
\hline Problemas ansiedade & $60.52(9.08)$ & $58.40(6.79)$ & 0.18 \\
\hline Problemas somáticos & $58.32(9.71)$ & $59.60(9.90)$ & 0.19 \\
\hline Atenção/Hiperatividade & $62.24(9.03)$ & $57.76(7.38)$ & 0.19 \\
\hline Desafiador opositivo & $60.40(7.18)$ & $57.84(6.24)$ & 0.24 \\
\hline Problemas conduta & $60.00(8.46)$ & $54.20(6.48)$ & 0.19 \\
\hline Tempo cognitivo lento & $55.60(6.97)$ & $55.60(13.97)$ & 0.13 \\
\hline Problemas obsessivos & $59.96(10.56)$ & $58.48(8.30)$ & 0.24 \\
\hline Estresse pós-traumático & $61.80(9.49)$ & $36.55(8.64)$ & 0.25 \\
\hline
\end{tabular}


Todas as magnitudes de efeito foram baixas $(E S<0.33)$. Não sendo então identificadas diferenças clínicas significativas no comportamento infantil avaliado pelo CBCL após a intervenção com o PROPAIS II.

Além das análises comparando os escores dos participantes nos dois momentos de intervenção, foi realizada também uma categorizada da população do estudo, no momento da pré- testagem e, posteriormente à intervenção, de acordo com os níveis de gravidade fornecida pelo CBCL. O instrumento fornece três categorias: clínica, limítrofe e não clínicas, no entanto as duas primeiras foram agrupadas nesse estudo, portanto os dados serão apresentados apenas em duas categorias: clínica e não clínica. A categorização em gravidades foi realizada para as seguintes variáveis: competência social, que engloba as atividades infantis, questões escolares e desempenho social; problemas internalizantes e problemas externalizantes. A classificação dessas gravidades para os participantes que receberam a intervenção encontra-se na tabela seguinte: 


\section{TABELA 6}

Classificação das Crianças quanto à Gravidade de Problemas de Comportamento a partir dos T-escores obtidos no Pré-teste e Pós-teste.

\begin{tabular}{|c|c|c|c|c|c|c|}
\hline Participantes & Comp. Pré & Comp. Pós & P. Inter. Pré & P. Inter. pós & P. Exter. pré & P. Exter. pós \\
\hline 1 & Clínica & Clínica & Não Clínica & Não Clínica & Não Clínica & Não Clínica \\
\hline 2 & Clínica & Não Clínica & Não Clínica & Não Clínica & Não Clínica & Não Clínica \\
\hline 3 & Clínica & Clínica & Clínica & Não Clínica & Clínica & Clínica \\
\hline 4 & Clínica & Clínica & Clínica & Clínica & Clínica & Não Clínica \\
\hline 5 & Clínica & Clínica & Clínica & Clínica & Clínica & Clínica \\
\hline 6 & Não Clínica & Clínica & Não Clínica & Não Clínica & Não Clínica & Não Clínica \\
\hline 7 & \# & \# & Clínica & Clínica & Não Clínica & Clínica \\
\hline 8 & Clínica & Clínica & Não Clínica & Não Clínica & Clínica & Clínica \\
\hline 9 & Clínica & Clínica & Clínica & Não Clínica & Clínica & Clínica \\
\hline 10 & Clínica & Clínica & Clínica & Clínica & Clínica & Clínica \\
\hline 11 & \# & \# & Clínica & Clínica & Clínica & Clínica \\
\hline 12 & Clínica & Clínica & Clínica & Não Clínica & Clínica & Não Clínica \\
\hline 13 & Não Clínica & Não Clínica & Não Clínica & Não Clínica & Clínica & Clínica \\
\hline 14 & Clínica & Clínica & Clínica & Não Clínica & Clínica & Não Clínica \\
\hline 15 & Clínica & Cínica & não Clínica & Não Clínica & Clínica & Não Clínica \\
\hline 16 & Clínica & Não Clínica & Clínica & Clínica & Não Clínica & Não Clínica \\
\hline 17 & Clínica & Clínica & Não Clínica & Não Clínica & Não Clínica & Não Clínica \\
\hline 18 & Não Clínica & Não Clínica & Clínica & Não Clínica & Clínica & Não Clínica \\
\hline 19 & Não Clínica & Não Clínica & Clínica & Clínica & Clínica & Não Clínica \\
\hline 20 & Clínica & Não Clínica & Não Clínica & Não Clínica & Não Clínica & Não Clínica \\
\hline 21 & Clínica & Clínica & Clínica & Clínica & Clínica & Clínica \\
\hline 22 & \# & \# & Clínica & Clínica & Clínica & Clínica \\
\hline 23 & \# & \# & Clínica & Clínica & Não Clínica & Não Clínica \\
\hline 24 & \# & \# & Não Clínica & Não Clínica & Não Clínica & Não Clínica \\
\hline 25 & \# & \# & Clínica & Clínica & Clínica & Clínica \\
\hline
\end{tabular}

Notas. Comp. Pré = Competência social no pré-teste. Comp. Pós = Competência social no pós-teste. P. Inter. Pré $=$ Problemas internalizantes no pré-teste. P. Inter Pós $=$ Problemas internalizantes no pós-teste. P. Exter. Pré = Problemas externalizantes no pré-teste. P. Exter. Pós = Problemas externalizantes no pós-teste. O sinal \# corresponde a casos de missing.

A frequência de ocorrência de cada uma das gravidades, nos dois momentos de intervenção é descrita na tabela abaixo: 


\section{TABELA 7}

Frequência de Ocorrência das gravidades Clínica e Não Clínica nas variáveis Competência Total, Problemas Internalizantes e Problemas Externalizantes nos dois Momentos da Testagem.

\begin{tabular}{lcccccc}
\hline & Comp. Pré & Comp. Pós & P. Inter. Pré & P. Inter. Pós & P. Exter. Pré & P. Exter. Pós \\
\hline Clínica & 15 & 13 & 16 & 11 & 16 & 11 \\
Não Clínica & 4 & 6 & 9 & 14 & 9 & 14 \\
Missing & 6 & 6 & 0 & 0 & 0 & 0 \\
\hline Notas. Comp. Pré = Competência social no pré-teste. Comp. Pós = Competência social no pós-teste. P. Inter. \\
Pré $=$ Problemas internalizantes no pré-teste. P. Inter Pós $=$ Problemas internalizantes no pós-teste. P. Exter. \\
Pré = Problemas externalizantes no pré-teste. P. Exter. Pós = Problemas externalizantes no pós-teste.
\end{tabular}

Muitas das crianças enquadraram-se na gravidade clínica tanto no pré quanto no pósteste, para verificar a existência de diferenças nos dois momentos de intervenção foi realizada a análise com o teste de McNemar. Dos 25 participantes, 19 foram analisados pelo teste, os 6 restantes não responderam todos os itens, sendo considerados missing.

Não foram encontradas diferenças estatísticas na modificação de categorias entre o pré-teste e o pós-teste. As análises foram realizadas separadamente para: Competência total $(\mathrm{p}=0.63)$, Problemas internalizantes $(\mathrm{p}=0.06)$ e Problemas externalizantes $(\mathrm{p}=0.13)$.

\subsection{Correlações entre instrumentos.}

Visando identificar possíveis relações entre os instrumentos foi realizada uma correlação não paramétrica de Spearman entre as escalas totais e as subescalas da EQIF com todas as variáveis mensuradas pelo CBCL. No entanto não foram encontradas correlações fortes ou médias e, portanto, os resultados da análise não serão apresentados nesse estudo.

\subsection{Análises qualitativas da participação nos grupos.}

A partir da análise dos relatos registrados foram elaboradas quatro categorias temáticas, com base na repetição das falas coletadas, são elas: Problemas encontrados no educar, sentimentos dos participantes, mudanças e papéis do grupo. Cada uma delas é composta por subcategorias, que as exemplificam melhor, como descrito a seguir: 


\begin{tabular}{|c|l|}
\hline Categorias & \multicolumn{1}{|c|}{ Subcategorias } \\
\hline $\begin{array}{c}\text { 1. Problemas } \\
\text { encontrados no } \\
\text { educar }\end{array}$ & $\begin{array}{l}\text { Queixas sobre o comportamento dos filhos e influências do } \\
\text { contexto familiar. } \\
\text { Problemas relacionados às práticas educativas parentais } \\
\text { Dificuldades relacionadas ao cônjuge e divisão de tarefas } \\
\text { Problemas relacionados ao modelo dos pais }\end{array}$ \\
\hline $\begin{array}{c}\text { 2. Sentimento dos } \\
\text { participantes }\end{array}$ & $\begin{array}{l}\text { Culpa e angústia decorrente de falta de tempo para as crianças } \\
\text { Pena afetando as práticas parentais } \\
\text { Estresse, raiva e dificuldade em aceitar emoções desconfortáveis }\end{array}$ \\
\hline 3. Mudanças & $\begin{array}{l}\text { Relacionadas a práticas educativas positivas } \\
\text { Flexibilização de cognições } \\
\end{array}$ \\
& $\begin{array}{l}\text { Manejo de emoções } \\
\text { Mudanças nos comportamentos infantis } \\
\text { Modificações na evolução das sessões }\end{array}$ \\
\hline 4. Papéis do grupo & $\begin{array}{l}\text { Espaço para obter informações } \\
\text { Identificação e coesão grupal } \\
\text { Difusão de informação a não participantes }\end{array}$ \\
\hline
\end{tabular}

\section{FIGURA 1}

Categorias e Subcategorias levantadas a partir do relato dos participantes do grupo de intervenção

A primeira categoria aborda a temática dos Problemas englobando tanto as queixas que os pais trouxeram de seus filhos, como suas próprias dificuldades, que em sua percepção, influenciavam em suas práticas educativas e formas de interagir com os filhos. A segunda categoria refere-se aos Sentimentos dos participantes relacionados à educação de seus filhos. Engloba sentimentos iniciais a intervenção e também ao final desta. As relações entre sentimentos e as práticas educativas são também componentes dessa categoria.

A terceira categoria, intitulada Mudanças, abarca a percepção dos entrevistados das modificações em seu próprio comportamento, comportamento de seus filhos e na forma de enxergar algumas situações relacionadas à educação das crianças de maneira diferente e realista. A última categoria engloba os Papéis do grupo, sendo composta pela percepção dos participantes de todas as funções que o grupo adquiriu para eles.

Os relatos serão apresentados apenas nas categorias principais, servindo às subdivisões das mesmas apenas para ilustrar os diferentes aspectos componentes de cada uma das categorias levantadas. Apesar de pequenas diferenças na caracterização dos seis grupos que foram oferecidos, muitos relatos dos participantes se assemelham, portanto serão trazidos em conjunto. As falas representativas das quatro categorias levantadas estão descritas abaixo e seus autores são identificados segundo o quadro de participante já apresentado em anexo. (Anexo E) 


\subsubsection{Problemas encontrados no educar.}

No decorrer das intervenções, sobretudo nas duas sessões iniciais, os pais compartilharam alguns os problemas que encontram na educação de seus filhos. Esses relatos auxiliaram na preparação de sessões que abarcassem as dificuldades de cada um deles, apesar de uma mesma estrutura base de programa ter sido usado nos seis grupos. Algumas falas, como as apresentadas abaixo, expressam dificuldades específicas do comportamento das crianças e/ou do contexto familiar:

Eu que cuido do meu neto, sabe? A mãe largou ele bebezinho, recém-nascido mesmo, lá em casa... ela tava envolvida com droga, com coisas ruins, aí eu fui ficando com ele e fiquei! O pai também, sabe? Meu filho (emocionada), também usa... Aí o Pedro (neto) tá comigo até hoje, eu que faço tudo. Ele é um menino muito bom, mas é difícil sabe? Ele é muito agitado, tem TDAH (...) ele passa na médica e na psicóloga prá tratar, mas ainda tá muito agitado, não pára quieto, é difícil dele prestar atenção! Isso é, acho, a coisa mais difícil né?! (Vivian)

"A minha filha chora toda vez a professora fala que ela errou alguma coisinha e corrige ela. Ela tem muito medo de errar. Eu acho ela muito insegura, me preocupo com ela!" (Esther).

"Meu menino é muito inibido, não pede ajuda para a professora quando tá com alguma dificuldade, mas com a gente em casa ele pede e fala bem. Eu queria que ele ficasse mais solto com os outros." (Sarah).

Ela é boazinha, mas eu ameaço se ela faz bagunça (...) digo que não vai passear, se ela não arruma o quarto, tipo isso! E não levo, porque senão ela não aprende né! (...) Mas o complicado nem é ela na verdade, lá na casa, mora muita gente sabe? Eu que cuido dela, mora mais quatro irmãos homens, eles falam muita besteira! Eu não gosto que ela fale, mas ela escuta muito aí eu falo: Filha não pode falar assim, eles falam errado, é feio! Acho que eu consigo lidar bem com elas, eles que são mais difíceis! (Marcos)

Eu tenho que mandar tomar banho um milhão de vezes, ele enrola, fica dando desculpa - ah mãe, agora tô vendo desenho, só mais um minutinho - e nunca vai. (...) Tem 
uma outra coisa que me incomoda muito lá em casa! Cada um, na hora do banho, tem a sua toalha, né? Eu não gosto que use a minha toalha! Mas as crianças pegam, ficam com preguiça de pegar as delas, aí agarram a minha que tá sempre lá, eu não gosto e brigo! O meu menino obedece, mas a menina não. Aí eu falo que vou brigar, deixar de castigo, eu deixo às vezes... mas aí quando eu esqueço o menino começa a desobedecer também e também usa a minha toalha! (Maria)

Eles reclamam que a gente não sai, pedem pra sair, da um rolê... às vezes ela quer só entrar no carro e dar uma voltinha. Mas é difícil lá em casa, eles não saem sozinhos, é perigoso... e meu marido trabalha o dia inteiro, aí a gente fica só em casa. (Elisa)

Outros sinalizam dificuldades do cotidiano em que não sabem como lidar e seus sentimentos e comportamentos frente a isso:

$\mathrm{Eu}$ falo e parece que tô falando com uma porta. O meu filho mais velho é muito grudado comigo, até atrapalha meu relacionamento, chora muito, é ansioso, estabanado! Quer sempre impressionar, chamar atenção, ele tem muito medo de dormir sozinho, ele é grudado! Um dia meu marido ficou bravo comigo, agressivo, começou a gritar e ele foi lá me proteger! (Mariana)

Eu tenho duas meninas e elas brigam sem parar, é o maior problema. Eu não aguento, me estresso... quase todo dia eu bato. Elas morrem de ciúme uma da outra, a mais velha chora quando eu brigo, mas ela tá quase sendo expulsa da escola por mau comportamento. (Eliana)

A gente não sabe mais como lidar com ele, ele já colocou fogo perto de casa, é famoso sabe! Aqui na Ong é só falar "Oi, eu sou a mãe do Arthur" que todo mundo já faz aquela cara... na rua também, o Arthur tá famoso, mas não por nada bom! Ele apronta sem parar! (...) Ele só fala gritando, já tentei isso de ignorar, mas ele fica no castigo, o tempo todo, acha algo pra fazer, aí cansa e fica gritando! É cansativo, eu não aguento! (Solange)

O que é ruim é que eu tenho que fazer tudo pra ele, eu que pego cueca, toalha, roupa"... faço a bolsinha de escola dele todo dia! De manhã eu boto água e remédio na boca dele ou ele não toma. Até ano passado, que ele tava com seis anos, eu tinha que segurar o 'pipi' dele e mirar no vaso pra ele fazer xixi... aí esses dias eu tava com ele na rua e ele pisou numa semente que mancha e 
tirou o chinelo! Ele tacou o chinelo e me mandou pegar ele, e eu não fui! Eu falei pra ele assim... ou você cata esse chinelo ou vai ficar descalço porque eu não vou comprar outro de jeito nenhum! Aí ele ficou me olhando (risos), criança testa a gente né?! E eu não fui e ele voltou correndo e chorando pra buscar! (...) mas é difícil ser assim sempre, ele sempre chora quando eu não faço o que ele quer e aí eu desisto e vou lá e faço pra ir mais rápido! (Aline)

Os problemas que apareceram nos grupos eram diversificados e centravam-se mais em queixas externalizantes, no caso de Aline e Sarah, queixas internalizantes também são reconhecidas como problemas no cotidiano familiar. A fala de Aline mostra tanto a tentativa de agir diferente com seu filho, quanto às tendências de comportamento que possui, além da dificuldade de manter a mudança, mesmo tendo observado que ela funciona em algumas ocasiões.

Adicionadas às queixas sobre o comportamento dos filhos, contexto familiar e dificuldades em agir diferente com as crianças, alguns participantes trouxeram dificuldades e opiniões específicas de suas práticas parentais. Por exemplo: o que acreditam que dá certo, tentativas que não estão funcionando e desafios de modificar o comportamento de seus filhos, como relatado abaixo:

Em casa o negócio é bagunça, um dia cheguei em casa e ela tinha feito a faxina até. do jeito dela, mas fez. Aí eu elogiei. só que disse pra ela que tinha faltado a garagem e ela ficou mal (...). Às vezes a gente fala... não é criticando, né... é o hábito! Minha filha só tira sete e oito na escola, sete e oito sempre! Aí eu falo, é pouco, tem que estudar mais e ela "ai mãe, mas eu tô na média" e não, a média tem que ser 10, ela não tira 10. Aí falei que ela é boa de comportamento na escola, mas tem que estudar mais! (Elisa)

“Eu já tentei de tudo, tirei videogame, já tirei várias coisas, já tirei TV... parece que ele não tá nem aí prás consequências." (Carla)

O meus problema também é com mau comportamento dos meninos. Mas eu cansei e não brigo mais, de um tempo pra cá eu dou gelo neles, se precisar fico sem falar e de cara feio o dia todo, é isso só que tem feito eles sossegarem. (Vera) 
Esses dias ele largou a chuteira de novo, na sala! Aí eu cheguei e já fui direto, tropecei e quase me esborrachei na sala por causa dessa chuteira! Eu falei pra ele: a próxima vez que eu achar essa chuteira aqui eu vou enfiar ela na sua cara! Aí guardou! (Maria)

Meu neto começou com uma mania de pegar coisa que não é dele... tá acontecendo algumas vezes e eu tô preocupada. Não sei bem o que fazer (...) na quarta ele pegou uma caixinha de tic-tac do supermercado sem eu ver, aí eu vi e perguntei pra ele: o que acontece quando a gente pega uma coisa e sai sem pagar? Ele ficou quieto e eu fiquei muito brava, botei ele no quarto pra pensar o dia todo. Aí no dia seguinte ele vai e pega uma moeda do tio sem pedir! Que a gente faz? (Silvia)

As mães apontam algumas práticas que utilizam no dia a dia, algumas que funcionam momentaneamente, apesar de conterem ameaças e retraimento, como no caso de Maria e Vera. Refletem também frustração por não conseguirem melhorar alguns comportamentos dos filhos, como relatado por Sílvia e Carla e, percepções de que, por hábitos acabam dizendo e fazendo coisas que não são as mais adequadas para a educação das crianças, como na fala trazida por Elisa.

Os participantes trouxeram também algumas dificuldades relacionadas a seus cônjuges. Essas, parecendo influenciar no clima família, na educação das crianças e nos sentimentos dos pais:

O pai enche a cabeça do menino... é a coisa mais difícil prá mim! O Júlio tá até meio assim... meio perdido tadinho! O pai dele não pensa nada parecido comigo, nada a ver sobre a separação, ele briga, fala mal de mim pra ele. ele vem às vezes super triste e me fala, com medo de eu ficar brava e triste também! Eu tento proteger ele, filho não tem que saber de briga de pai, mas ele não me ajuda, tenho muito medo dele botar meu filho contra mim! Aí o Júlio chega em casa e fala que não vai mais me falar nada que o pai contar porque não quer que eu fique triste (...) ele só tem oito anos! Não sei lidar direito com essas coisas não!" (Edite - contando ao grupo sobre seu processo de separação)

"O meu marido não faz nada e eu fico super sobrecarregada"! (Aline - ao responder ao questionamento dos terapeutas sobre o que achavam que era função do pai) 
"Ah, eu brinco com ela, pai é bom pra brincar, mas quando é coisa séria, vixi, eu saio de perto e ela vai com a mãe e fica 'mãe, olha lá o pai',". (Pedro)

Nas falas aparece bem marcado o papel da mãe, mas não o do pai: quais as funções, de que forma deve ajudar, mostrando uma sobrecarga de tarefa e emocional nas mães que relataram os problemas. A fala de Paulo também traz a questão dos papéis, parecendo que para ele existe o que é coisa de mãe e o que é coisa de pai. E, que nos momentos difíceis é a mulher que resolve os problemas e é a ela que a filha busca, parecendo já acostumado a essa situação.

A fala de Edite também aponta um aspecto delicado: o divórcio dos pais e a influência disso para o filho, quando a separação não ocorre de forma amigável. Além de se preocupar com o menino, a situação do divórcio evoca sentimentos desagradáveis em si.

Além de queixas específicas das crianças e características de contexto e relacionamento com os cônjuges, alguns participantes trouxeram relatos acerca dos problemas que enxergam em si mesmos. Observam também que são modelos para o comportamento infantil e que devem estar atentos a suas próprias atitudes:

A gente fica reclamando às vezes, das coisas ruins que eles fazem, de não se comportar, mas em que ter disciplina, rotina... nem a gente tem, sabe? La em casa eu quero que eles sentem direitinho na mês pra comer, mas eu mesma como no sofá vendo a novela... eu falo que é feio mentir, mas quando liga alguém em casa pra falar com o pai e ele não quer, manda dizer que não tá. Eu quero conseguir ter isso de rotina, se não não adianta ensinar pra eles e fazer o contrário. (...) Lá na minha irmã é tudo organizando, tem regra, tem rotina e as crianças são organizadinhas e obedientes também, da até gosto! (Maria)

A minha filha esses dias foi quem deu uma bronquinha em mim (risos), eu tirei o livro sem pedir da mão dela e ela disse: Ah você falou que não pode fazer assim, você ia gostar que fizesse assim com você e tirar o livro sem falar nada? (Carla)

"Ele disse que era feio dirigir falando no celular... ele tá certo, eu tive que pedir desculpa e guardei o celular." (Esther) 
As meninas não dormem cedo, mas eu também deito super tarde. Comecei a tentar fazer diferente, coloco elas pra dormir antes, aí se elas dizem que não tão com sono, falo pra elas ficarem deitadinhas e pensarem numa cachoeira. Às vezes elas não dormem, mas ficam mais calmas. (Diane)

A compreensão de que são modelo para o comportamento dos filhos veio cedo para muitos participantes, sendo todas essas falas coletadas até a segunda sessão. Essa conscientização parece trazer tentativas de mudanças de hábito dos familiares, para que as crianças também possam mudar.

Por fim, outro problema que foi expresso nas sessões, parecendo dificultar na educação das crianças foi a falta de tempo. Essa, ilustrada pela fala de Marina, que em outros momentos da intervenção, foi compartilhada por muitos participantes, sendo utilizada como dificuldade principal em educar, trazendo sofrimento para os pais:

O que mais me complica, sabe... é a falta de tempo! Não da tempo! A criança faz o que quer o dia inteiro e a gente tá longe, trabalhando. Aí você só fica sabendo depois e não dá tempo de fazer muita coisa, não tem muito jeito. (Marina)

\subsubsection{Sentimento dos participantes}

Apesar de sentimentos e comportamentos aparecerem em conjunto no relato dos pais, algumas falas enfocam principalmente o que os participantes sentem ao educar suas crianças. Nessa categoria o enfoque é tanto para os sentimentos que desprendem das práticas educativas, quanto do comportamento das crianças e das próprias expectativas dos participantes quanto a seu desempenho como pais. A questão de falta de tempo também apareceu nessa categoria, despertando sentimentos de culpa e angústia nas mães:

Eu não consigo dar toda a atenção que ela quer sabe? Ela quer atenção o tempo todo, mas eu trabalho todos os dias da semana, até de sábado. Sobra um pouquinho só no domingo, não é suficiente pra ela, e pra mim, também é muito cansativo... fico cansada e fico chateada também, por ela né (...) acho que isso é o mais difícil! (Thaís) 
“Quando eles eram pequenininhos eu trabalhava demais, quase nunca tava em casa. Agora eu tô colhendo os frutos dessa minha falta e tô tendo dificuldade para recuperar." (Mariana)

"Eu me sinto culpada demais por trabalhar fora em tempo integral. Aí quando eu chego em casa eu quero ficar junto, fico feliz, não tô nem aí prá mais nada!" (Érica)

Dificuldade na expressão de afeto também foi um problemas apontado por algumas participantes:

Esse negócio de ciúme, não gosto, é difícil! A menina fica dizendo que não gosto dela, só do outro, do menino. Morre de ciúme, mas não vem (...) não vem pra dar carinho, pra pedir, mas quer que eu vou! Aí é difícil pra mim... eu sou meio travada! Ela fala que eu gosto mais do menino, mas não é, gosto dos dois, amor de mãe é tudo igual! (Elisa)

A professora da minha mais velha me chamou lá na escola de novo. Parece que ela ameaçou uma menina menor lá, eu nem consegui conversar ou perguntar pra ela, eu tava morrendo de raiva. (...) Ela me disse que faz coisa errada porque eu não gosto dela, eu fiquei pensando, eu não sei o que acontece, mas com ela eu não consigo me abrir. (Eliana)

"Meus filhos são amorosos sabe, muito amorosos! Abraça, beija, aperta... o tempo todo, sufoca!! Aí eu fico nervosa e acabo brigando com eles, eu não sou assim! (Maria)

"O meu é assim, é igual, ele pega até no meu peito na frente dos outros, fico morrendo de vergonha." (Aline - completando a fala de Maria)

Não é fácil não (risos), isso de voltar atrás, falar que tava errado ... eu não sei muito fazer isso não, acho que eles vão estranhar (...) mas eles pedem sabe, desculpa e fala que tavam errado depois que brigo ou que falo pra eles que não gostei (...) aí eu digo que perdoo, mas no fundo no fundo eu ainda fico magoada!" (Elisa- sobre pedir desculpas para o filho, uma das temáticas trabalhadas em sessão) 
As mães desses relatos expuseram algumas dificuldades em mostrar afetividade a seus filhos, sabendo da necessidade de fazê-lo, mas sentindo certo estranhamento em demonstrar carinho em algumas situações, por questões que atribuem a seu jeito ou personalidade. Enfocar dificuldades específicas dos pais, que podem interferir na educação das crianças, mostrou-se importante para que as mães conseguissem se expressar melhor e vencer seus próprios desafios.

Em vários momentos os participantes relataram que se sentem impotentes e/ou com dúvidas sobre como se sentir e se portar. Sentimentos esses despertados pelos comportamentos das crianças frente a situações difíceis ou ao emitir maus comportamentos:

Eu não sei o que fazer com ele, é um sentimento esquisito e muito ruim, às vezes eu só choro! A menina é muito fácil, nunca deu tanto trabalho, eu sei lidar, mas ele, sei lá (...) quando ele chora, não adianta abraçar. Bater não dá porque ele é muito forte e às vezes até me machuca, e sai mais revoltado ainda quando bate, então não dá! Ele era quietinho sabe? Não entendo... mudou do nada, parece! Parece que agora conforme cresce, pensa que é homem já e que pode fazer o que quiser! Eu tô muito cansada, mas mãe não pode desistir né?! Que que eu vou fazer? (...) A menina é diferente, ela até chora quando não faz a lição direito, ele engana que não tem lição e aí a professora conta que tem todo dia! É impossível, não tenho mais forças! (Solange)

Com o meu neto toda vez que eu grito ou fico brava com ele, ele ri! Eu falo: vai ficar de castigo, ele ri e sai andando! Aí eu não sei como lidar e não faço nada! Às vezes dá muita raiva, às vezes eu acabo rindo também! Não tá funcionando muito castigo! (Anita)

“Ele chora demais, isso me deixa nervosa! É só eu começar a chamar atenção dele porque fez coisa feia que ele abre o berreiro! Aí me dá dó e eu paro, não faço nada do que tinha pensado!" (Aline)

Eu não tenho coragem de bater neles, às vezes a gente lembra que já sofreu, apanhou muito! Não posso fazer isso com eles, não dou conta, eu me sinto muito mal! Sou mil vezes tirar alguma coisa, dar castigo (...) mas aí também se não for em casa é na rua, no mundo! A gente fica entre a cruz e a espada! (Solange) 
Sentimento de pena ou dó, dificultando a emissão de práticas educativas necessárias adequadas também apareceu nos relatos dos pais:

'Eu não deixo fazer nada... eu não espero, eu não consigo ver que tá difícil, me dá dó e eu fico sem paciência também. Aí eu já vejo tudo e vou catando." (Aline, contando sobre sapatos, roupas e brinquedos jogados pela casa)

Ela (neta) teve depressão e pânico faz dos anos. Eu entrei no grupo prá poder cuidar melhor dela... ela viu tanta coisa, tanta coisa irresponsável que a mãe fez, que eu tenho muita dó! Mas eu tenho medo também, porque eu não consigo falar muito não e ser firme com ela, mas também tenho medo disso atrapalhar lá na frente pra ela, é difícil! (Sílvia)

Raiva e estresse foram sentimentos comuns frente aos problemas comportamentais externalizantes das crianças, como exemplificam as falas a seguir:

"Eu me estresso muito e acabo batendo pra elas pararem de brigar, de responder, agora eu tenho que me controlar não sei como, porque se não os vizinhos falam pro Conselho Tutelar.” (Eliana)

"E quando meu filho chora quando eu dou bronca?! Isso me irrita muito, dá vontade de bater!" (Carla)

Todos os sentimentos desconfortáveis trazidos pelas mães evidenciam novamente a importância de se trabalhar aspectos emocionais além do treino para mudança comportamental infantil. Por fim, em alguns momentos, os participantes questionaram nos grupos acerca da normalidade de sentirem emoções desconfortáveis e tiraram dúvidas acerca dos estados emocionais de seus filhos. Alguns exemplos:

“A culpa é nossa quando nosso filho é inseguro?” (Maria)

Minha filha se preocupa demais comigo, isso é de criança? É normal ficar preocupado?!” (...)“É normal criança falar na cara? Falar sempre a verdade mesmo quando é inconveniente?! Eu sei que não deve ensinar a mentir, mas eu fico com vergonha às vezes das coisas que ela conta na frente dos outros! (Esther) 
"Pode sentir raiva do filho? É até feio falar isso... mas às vezes me da raiva!” (Maria)

É... eu tenho isso às vezes também sabe! Não queria sentir, mas a hora que vejo já tô triste e com raiva; esses dias o meu neto mais velho chegou em casa tarde! E eu fui dar bronca nele, eu tava preocupada e ele gritou comigo! Eu passei um nervoso, é eu que dô tudo pra ele, eu que crio e ele ainda fala essas coisas! Viu, dá raiva de novo de falar! (Anita, completando a fala de Maria)

\subsubsection{Mudanças.}

No decorrer das sessões, os participantes relataram várias mudanças em seu comportamento e pontos de vista. Observaram também algumas modificações nos comportamentos infantis. Algumas dessas estão descritas abaixo:

\subsubsection{Modificações relacionadas ao aumento de práticas educativas positivas.}

\section{Elogios:}

Eu tento elogiar ele, sabe? No começo ele gostava, ficou mais amoroso, mas o Arthur é difícil, ele agora fica fazendo gracinha, tentando chamar atenção, de repente volta a gritar tudo de novo, depois chora... não consigo elogiar muito, às vezes eu fico tão sem saber o que fazer... o grupo me ajudou, mas eu ainda fico perdida! Ele não obedece, ele é impossível! (...) Eu mando fazer alguma coisa e aí ele não faz! Tem que ser mansinho, pedir por favorzinho, e bem calma, aí ele vai... isso tá funcionando, mas é difícil ficar calma com ele viu!(Solange)

$\mathrm{Eu}$ tentei isso do elogio de novo, é engraçado o que acontece, né? Meu neto tava fazendo a tarefa de caligrafia dele que a professora passou, porque a letra dele é complicado, né, muito desleixada! Aí eu vi fazendo certinho e falei: nossa, agora tá bem bonitinha sua letra! E ele ficou feliz demais (risos)... ele começou a arrumar as outras que tavam feias também! (Anita) 
Eu elogiei mais ela sabe, igual vocês falaram, aí (risos) deixa contar uma coisa que aconteceu? Eu escrevi assim, deixei um bilhete de manhã pra ela, lavar a louça e garagem pra me ajudar, e escrevei 'te amo' no final. Aí eu cheguei em casa e ela limpou a garagem e também me deixou um bilhetinho: ' mãe, também te amo. Amanhã lavo a louça. (Elisa)

Ainda sobre o tema elogios, em um momento descontraído de uma sessão intermediária do programa, Maria contou que a filha também a elogiou. Disse ao grupo que, quando elogiou a filha e agradeceu por ter arrumado a casa, ela se espantou e disse: "Nossa mãe essa reunião tá boa heim, acho que você devia ir toda segunda". Outros participantes do grupo comentaram rindo que alguns de seus filhos já haviam dito coisas semelhantes sobre a mudança de comportamento deles em casa.

Elogio foi a prática educativa positiva mais comentada por todos os participantes ao longo das sessões. Ao começarem a utilizar em casa e notarem mudanças, passaram a considerá-la uma prática transformadora. Ao longo das sessões perceberam também, agora de forma mais realista, que elogios precisam ser dados em momentos certos e que toda mudança de comportamento demora e depende de um conjunto de esforços dos pais, sendo um processo contínuo.

\section{Monitoria Positiva:}

Eu ficava esguelando sabe? Bruno vai pra esse banho logo, falo mil vezes, aí essa semana eu tentei fazer diferente, fui lá na sala, não gritei de longe e mandei ir tomar banho imediatamente... eu não gritei, mas tava firme, sabe?! Aí ele foi, de primeira, emburradíssimo, mas foi! Foi muito mais tranquilo pra mim do que a gritaria de sempre! (Maria - sobre a maior dificuldade com o filho)

Tem que explicar o porquê daquilo, né? Ação e reação. A gente pensa que é assim, "sou eu que estou falando e pronto, acabou", agora entendo que não é bem assim que fica na cabeça dos meus filhos. Eu tô tentando explicar mais. Tudo o que eu faço por eles é por amor. Eu não estou mais batendo nem gritando, eu melhorei. (Elisa)

Eu tô tentando parar de reclamar e brigar tanto com ela de manhã pra ir pra escola. Dei parabéns quando ela 
levantou sozinha sem reclamar. Faz uma semana que ela tà acordando sozinha, não reclama, vai mais sorridente. Tá muito legal ver ela assim! (Carla)

Eu sempre quis estar bastante com ela, sabe? A mãe não está, eu quero fazer algo, sei lá, pra compensar isso pra ela. Não sei se tem como, mas eu tento. Eu beijo muito, abraço, levo ela pra fazer coisa que gosta, mas não consigo sempre por conta de trabalhar. Sempre eu tentei isso, agora eu tento só não falar muita coisa negativa pra ela. Tipo, quando eu tô ruim ou preocupado, não posso contar pra ela, ela fica triste também, preocupada. (...) Mas se eu tivesse que escolher alguma coisa, que sei lá, me ajudou, além de poder ouvir os outros pais aqui do Núcleo, é que eu não posso não cumprir as coisas que prometo pra ela né? Porque ela fica esperando, e eu tô tentando ficar mais tempo com ela! Ela fica demais em casa com a família toda, é muita gente, irmão, tio. Mas tô tentando ficar o máximo possível com ela, ela gosta muito... e eu também! (Marcos)

Acompanhar mais os filhos e estar mais presente foi um esforço demonstrado por vários dos participantes nas sessões. Tentativas de mudar práticas mais agressivas para adequadas, juntamente com o uso de elogios e observações disso no comportamento infantil foram aspectos também ressaltados nas sessões e que parecem ter gerado consequências positivas na interação familiar, como previsto.

Flexibilização de pensamentos, identificação de distorções e consciência de que são modelos para os filhos:

Em relação às cognições, os relatos dos participantes na avaliação final centraram-se mais na autopercepção e na observação de como seus pensamentos e sentimentos precisam ser acessados para que possam escolher melhores maneiras de agir.

Nunca tinha parado para pensar nisso antes, sabe? Da relação das coisas, que como ela se comporta pode se relacionar, com o que eu me comporto... e que o que a gente pensa também pode fazer a gente agir diferente, sei lá, acho que nunca tinha parado pra pensar nisso e olhar, acho que é uma questão de refletir. (Elisa) 
Isso de perceber né, se a gente tá errando pra pensar e falar.. tipo, antes da regrinha (de questionar os pensamentos automáticos) eu fazia aquilo do oito ou oitenta direto (sobre a distorção cognitiva: 'tudo ou nada'). Se ela não fizesse tudo o que eu tinha pedido, não adiantava e não tinha passeio, brincadeira. Agora eu tô aprendendo a me segurar e avaliar. (Marcos)

Isso foi uma coisa que percebi mais do que mudar... mas me fez mudar também, acho. Minha filha, ela tinha três anos só na época... e eu estava muito estressada, eu vivia xingando o pai dela em casa, reclamava que ele demorava para chegar e um dia quando ele chegou ela virou pra ele pequenininha e disse: "onde você estava, seu retardado? Você é um folgado, a mamãe tá nervosa por sua causa". Eu vi que tava fazendo mal pra ela, não é normal. Ela brigou e desrespeitou o pai por minha culpa, eu tive que me reeducar pra poder educar ela, não podia ficar assim! (Maria)

Acho que todo mundo era assim antes, não parava pra pensar, porque a gente não tinha as informações. Nessas seis sessões todo mundo começou a se policiar, eu melhorei muito. Gosto muito da minha filha, não dá pra ficar brigando. Agora eu paro antes. Às vezes não é nem deixar de falar, mas encontrar uma maneira melhor. (Marcos)

Agora que eu tô tentando ser mais consciente dessas coisas tá um pouco diferente sabe? (...) isso de que às vezes a gente é mais bravo quando já tá nervoso e desconta na criança! Aquilo que vocês falaram (sobre distorções cognitivas), eu vi mesmo que fazia várias... às vezes eu descontava nela, achava que era de propósito, ficava irritada demais por afronta, mas eu comecei a olhar de outro jeito! Tô vendo que nem sempre é assim... às vezes sou eu, não ela! (Fernanda)

\section{Manejo de emoções desconfortáveis:}

Algumas modificações referentes às emoções foram relatadas pelos pais, enfocando as emoções desconfortáveis. Nos momentos de raiva, em que normalmente agiam por impulso, os pais relataram uma habilidade maior para manter o autocontrole e pensar sobre a situação antes de tomar uma decisão, como sinalizado nos seguintes trechos: 
"Eu tenho feito muito aquilo de respirar, de contar até dez também quando eu fico irritada com alguma coisa." (Edite)

Depois que eu vim aqui, os meninos tão diferentes, eles abraçam mais, conversam mais, tão carinhosos. Até o avô já percebeu que eles tão diferentes um com o outro! Antes eles eram mais distantes (...). Eu mudei bastante também, agora eu não grito feito doida (risos). (Anita)

"Isso é uma coisa que sempre me policio... eu não posso descontar a minha raiva nas crianças, eu espero e tento saber por que eles tão agindo desse jeito." (Esther)

Tem que explicar porque daquilo né? Ação e reação... a gente pensa que é assim 'eu que estou falando e pronto e acabou!', mas isso é da raiva... do estresse. Pra mudar eu preciso treinar fazer diferente todo dia, é cansativo, mas se não for assim... a gente faz igual tudo de novo errado! (Edite)

\section{Mudanças no comportamento das crianças:}

Algumas falas dos pais indicam algumas mudanças que observaram em suas crianças após participarem dos encontros. Além de percepções diferentes acerca dos modos de educar, mesmo que não sejam fáceis de implementar ou manter. Dificuldade essa, que expressaram em muitos momentos dos grupos:

Eu tentei fazer diferente, ela fez bagunça na escola e eu coloquei de castigo, mas por menos tempo que antes e expliquei porque ela tava ficando de castigo e que não deveria mais brigar na escola. Depois que ela saiu do castigo eu abracei ela, mas ela brigou na escola de novo. (Eliana)

Lá em casa a menina tá fazendo, botei a regra, escrevi lá no quarto deles e ela já fez no mesmo dia! Tá toda animada (risos)! Ela tá quase com a folha cheia com tarefas cumpridas, arrumar a cama, fazer tarefa. Ela inventa tarefa prá ela só pra ganhar mais ponto! Tava assim no começo e ainda tá, tá durando. Já o menino ele fez nos dois dias, arrumou a cama, mas depois parou. Aí eu deixei ele sem assistir TV no sábado. (Elisa) 
Eu descrevo as coisas do dia dele, depois de acordar, (...) Depois da tarefa fazemos uma hora de lazer, todo dia uma coisa diferente. Tem dia que eu jogo videogame com ele, ou andamos de bicicleta, ele gosta muito e continua fazendo tudo direitinho quase todo dia. (Edite)

"Agora ele está conseguindo fazer diferente, não pega mais as coisas, ele tá me pedindo pra pegar os brinquedos emprestados"! (Sílvia - sobre neto de cinco anos que tinha desenvolvido o hábito de pegar coisas sem pedir e escondê-las).

"Eu não tô batendo nem gritando muito mais, tô mais paciente! Eu melhorei com eles!" (Elisa)

Ele (sobre o filho adolescente) tá diferente... ele quer ir pra Marinha, né, que nem eu falei, acabou de comprar um celular com o próprio dinheiro e, ele me pediu até ajuda prá escolher. Ele parece que tá se abrindo mais... e eu também. Acho que antes eu não parava prá ver o que ele tinha de bom, tava sempre azeda, reclamando, vendo defeito. (Vera)

Além de relatarem pequenas mudanças nas crianças e no modo como as educam, os pais perceberam que suas mudanças foram graduais. E, destacam como se sentiram no grupo, em relação às modificações de comportamentos, emoções e pensamentos que foram orientados a ter, tanto com as crianças, quanto com eles próprios e seus cônjuges:

“Agora que o grupo tá acabando eu já tô vendo alguns frutinhos, alguns! (risos), mas foi muito proveitoso estar aqui!" (Mariana)

"Nossa, mas a gente demora pra mudar né? Acho que a mudança maior foi em mim, não nas crianças, eu tô tentando maneirar e eles vão mudando conforme a gente vai entrando naquela rotina” (Carla -completando a fala de Mariana)

Uma coisa eu fui mudando, antes do grupo e ele ajudou também a ver que a gente tava indo no caminho certo... eu tinha problema com meu marido, eu dava uma ordem, ele outra, aí o menino ficava de lá pra cá pedindo coisa diferente, pra um, pra outro! Não dava... e acho que a culpa maior era nossa, a gente deixava ele confuso, coitado! Aí eu não faço mais isso não, quando ele fala, 
mesmo que eu ache ruim, eu não passo por cima não, mesmo errado! (...) Aí depois, longe do Pedro eu falo com ele e conversamos pra ver se tá certo, como a gente vai combinar as coisas. (Maria)

\section{Dificuldades:}

Apesar da maioria dos relatos indicarem melhoras e contribuições do programa, os pais em geral também ressaltaram algumas dificuldades. Essas centram tanto em analisar as situações e saber como agir, quanto a seguir algumas orientações do grupo e engajar-se em mudanças difíceis de implementar. Como exemplo disso está o seguinte relato, na avaliação final:

Eu tô tentando elogiar ainda, mas castigo ainda é mais difícil! Sempre foi, não sei como fazer! Ele faz birra e fica muito agressivo, eu não aguento, eu acabo deixando, porque não aguento ele gritar desse jeito, deixa todo mundo doido! Eu não sei muito bem agir com ele, sabe? Parece que não tem jeito! (Solange)

Falas assim sinalizam que a mudança não ocorre de forma simples e rápida, sendo necessário um trabalho longo. Tanto para a identificação de problemas e engajamento na implementação de novas soluções na busca de amenizar as dificuldades, o que é improvável de ser concretizado em uma intervenção breve.

Uma das participantes, ao final da última sessão, também contou sobre dificuldades, mas não com a implantação de mudanças específicas, mas como o papel de mãe e todas as responsabilidades envolvidas. Se despedindo dos terapeutas da seguinte maneira:

Olha, eu só digo isso pra vocês: ser mãe/pai é muito difícil. Quando vocês tiverem o de vocês, vão lembrar da dona Elisa. Vou estar muito velhinha, mas vão lembrar do que eu falava. Nessas horas você começa dar valor pra mãe, pra vó... [risos]. (Elisa)

Foram poucos os relatos diretos sinalizando dificuldades específicas da implantação do programa no decorrer das sessões, no entanto, essas foram identificadas em mais nos comportamentos dos participantes do que em seus relatos. Alguns exemplos foram: não terem conseguido, por muitas vezes trazer as tarefas propostas, muitas faltas ocorreram até que os grupos se vinculassem (por volta da segunda e terceira sessão) e dificuldade dos participantes em compreender alguns temas, como as distorções cognitivas e características de 
desenvolvimento, sobretudo quando se utilizavam nomenclaturas específicas, identificadas pelos terapeutas em sessão.

No entanto, ao serem questionados na avaliação final sobre possíveis adaptações e melhorias, em nenhum dos grupos foram feitas sugestões acerca de conteúdo, sendo que todos os pais afirmaram terem gostado e aprendido bastante. A única sugestão feita é que fossem realizados mais encontros, pois não gostariam de encerrar a participação. Acerca da duração do grupo, ao se perguntar sobre o número de encontros e se necessitariam de mais sessões, a afirmação da maioria foi que seria bom, mas que a duração também estava boa, pois não poderiam ir lá toda semana e não podiam deixar os filhos em casa muito tempo.

\subsubsection{Papéis do grupo.}

Os pais mostraram, em suas falas, alguns fatores que consideraram importantes de sua participação nos grupos. O primeiro elemento destacado é o grupo como um espaço para aprendizagem, onde orientações são fornecidas, diretamente pelos terapeutas e pela troca com os demais participantes:

$\mathrm{Eu}$ acho que os meninos, acho que meus filhos não precisam de psicólogo não, não tem nada grave (...), mas eu tô aqui no grupo pra aprender. Se precisar mudar eu mudo, tô curiosa, acho legal participar de grupo assim que ensina essas coisas pra gente! (Elisa)

"Eu gostei do grupo, vou sentir falta...aprendi pequenas coisinhas que fazem bastante diferença no dia a dia da gente!" (Fernanda)

"Foi muito bom ouvir as outras mães... a gente passa dentro de caso e não tem pra quem contar. É bom ter um esclarecimento, uma orientação !" (Maria)

Aprendi bastante coisa, de ouvir vocês (os terapeutas) e elas (as mães), eu conheci melhor as pessoas também, a gente só se encontrava às vezes pra trazer as crianças! Eu tô mais tranquila agora, de ouvir elas e deixar o meu filho, sei lá, um pouco mais solto, como elas disseram, né? (Aline) 
Duas sessões antes dessa fala, uma das mães tinha exposto sua opinião para Aline, cujo filho mostrava fortes comportamentos de dependência da mãe:

"Olha eu vou te dar uma dica, eu acho que a culpa disso é sua, sabe, uma parte pelo menos (...) ele não faz nada sozinho, você faz com ele e pra ele sempre, tem que desapegar um pouquinho!” (Maria)

Falas como essa demonstram o espaço de trocas, que foi mediado pelos terapeutas em diversos momentos da aplicação do programa, no entanto, alguns participantes destacaram diretamente a importância do convívio com os outros pais. Não apenas enfocando a troca de experiências, mas o sentimento de que compartilham problemas e que todos têm dificuldades a serem superadas, como expresso no seguinte relato:

O grupo foi legal... antes eu, bom era só eu que achava que tinha dificuldade, sabe? Problemas e coisas que eu não sabia lidar direito! Agora eu vejo que não tô sozinho de pensar assim, é difícil para todos, (risos), às vezes só um pouco diferente. (...) E agora eu posso usar algumas coisas que os outros pais já usaram lá na minha casa também, isso tem ajudado." (Marcos).

Alguns participantes destacaram também que não aplicaram as informações trocadas no grupo apenas com seus filhos, cônjuges ou em si próprios, mas em outros contextos. Além de ensinarem para colegas que não participaram, os temas e técnicas que aprenderam:

Mas aquele de respirar certinho (sobre a respiração diafragmática ensinada em uma das sessões). Mas eu não uso só com o Júlio (filho) não (risos) eu uso no trabalho, na fila, não é só filho que dá trabalho e deixa a gente nervoso, né? $\mathrm{E}$ eu tô passando pra frente, tudo que a gente aprende aqui, tem coisa que dá para passar para outras mães né?!(Edite)

“Eu passo tudo que aprendi aqui pro pessoal que não vem, amigo, família, vizinho, todo mundo que reclama que tem problema com filho...vou passando tudo adiante pra ver se ajuda também!” (Elisa)

Foi bom ter o grupo aqui na escolinha, mas isso devia ter em muito mais lugar, nas escolas das crianças, por 
exemplo. A gente se sente meio perdida! Quando meu filho começou a virar adolescente eu não sabia como lidar e a gente brigava muito. Se eu tivesse tido orientação na época eu teria feito as coisas bem diferente com ele. (Vera)

A fala de Vera, ainda sobre a ramificação das informações dos grupos para outros contextos, expressa o desejo de que o programa pudesse ser oferecido em outros locais. O que foi bem recebido pelos demais participantes de seu grupo, podendo ser considerado para outros estudos. 


\section{Discussão}

Ao longo desse estudo buscou-se caracterizar os participantes e o contexto de implantação do programa, de modo a conhecer o perfil geral dos mesmos, bem como as principais dificuldades e aspectos positivos presentes em seu cotidiano com os filhos. Comparações entre a caracterização e os pré-testes dos participantes que concluíram o grupo e os que desistiram também foram estabelecidas. Posteriormente, os resultados obtidos foram analisados pré e pós-teste para os 25 participantes que receberam o programa o modo a identificar os possíveis efeitos da intervenção para os participantes.

A discussão dos resultados será organizada seguindo o mesmo encadeamento dos resultados, no entanto, as análises qualitativas não serão discutidas separadamente, sendo utilizadas para complementar e exemplificar os resultados obtidos. Para finalizar serão enfocados os desafios de manejo da implantação do programa no contexto de promoção de saúde.

\subsection{Caracterização da amostra e do contexto da pesquisa.}

Como anteriormente mencionado, a demanda por intervenções familiares precoces e promoção e prevenção em saúde tem crescido, sobretudo pela detecção de aumento de problemas comportamentais e emocionais infantis. De acordo com Webster-Stratton e Hammond (1997) é necessário investir tanto em intervenções precoces de pais quanto de crianças, já que os problemas de comportamento tendem a se intensificar com o passar do tempo.

No Brasil essa demanda está fortemente presente, sobretudo no contexto de famílias carentes e/ou com pouco acesso às informações e orientações sobre formas adequadas de educação e manejo de problemas de comportamento infantil, que raramente são difundidas em meios de maior acesso, como escolas e unidades básicas de saúde. De acordo com Lambertucci e Carvalho (2008), em um contexto socioeconômico pouco favorecido os recursos físicos são insuficientes e, algumas vezes inadequados, investir em intervenções terapêuticas ou psicoeducacionais nesses contextos, enfatizando as relações familiares visando melhorar o repertório de comportamentos assertivos de pais e filhos que são 
fundamentais, sobretudo em locais relevantes e acessíveis às famílias e às crianças, como nas escolas.

Dialogando com essa demanda, o programa PROPAIS II foi proposto no contexto institucional em bairros de elevada vulnerabilidade social e baixa renda, em organizações fundadas na tentativa de oferecer fatores de proteção às crianças nesse contexto desfavorecido. O Critério de Classificação Econômica Brasil (CCEB) identificou que os participantes se distribuem nas Classificações de D (Baixa renda) até B1 (Classe média alta), havendo predomínio de participantes de Classe Média (C e B2) que aderiram ao programa.

Apesar de o CCEB ter detectado que a maioria dos participantes tinha possibilidades econômicas ao menos média, é importante ampliar essa caracterização, abarcando outros fatores sociais além do poder aquisitivo. Olhar para os fatores de vulnerabilidade dos bairros e dificuldades no contexto familiar que possam dificultar o acesso a recursos complementares de orientação , é importante para auxiliar os pais na educação de seus filhos.

As falas de alguns participantes sinalizam que dificuldades econômicas e do contexto em que vivem podem prejudicar a interação familiar e lançar desafios que se encontram despreparados para enfrentar. Como no caso de Elis, que relatou que os filhos pedem para que possam dar uma volta e ter atividades de lazer, mas que não conseguem por: precisar trabalhar em tempo integral, não ter outras pessoas que possam auxiliar com as crianças e temerem deixá-los saírem sozinhos, visto o bairro ser perigoso. Dificuldade com uso de drogas e preocupação da influência dos usuários nos filhos também foram questões destacadas pelos pais, que constituem fatores de vulnerabilidade exigindo atenção. Marinho (2005) destaca que alguns fatores contextuais podem inclusive influenciar a adesão dos pais à intervenção e à efetividade da mesma em suas famílias. De acordo com a autora, há pais que não obtêm benefícios e outros que abandonam prematuramente a intervenção, sendo enfatizado o papel de fatores ambientais desfavoráveis como: situação socioeconômica crítica, problemas conjugais, sintomas depressivos, famílias monoparentais, número elevado de eventos estressores no cotidiano familiar e práticas negativas nos cuidados com as crianças.

Em relação à composição e estrutura familiar dos participantes do PROPAIS II, a maioria das famílias era nuclear, com pai, mãe e filhos. Houve também duas famílias monoparentais, após separação e famílias chefiadas pelos avós, responsáveis pela educação dos netos, corroborando com a literatura de predominância brasileira de estrutura nuclear de família, coexistindo com modificações estruturais (Baptista, Cardoso, \& Gomes, 2012). Volta-se a atentar para a necessidade de sempre adequar as intervenções aos participantes, 
levando em consideração as diferentes configurações familiares dentro de um grupo, ao intervir, de acordo com as reflexões traçadas por Fonseca (2005).

A maior participação nos grupos foram de mães, tal como em demais programas de orientação de pais brasileiros (Bolsoni-Silva, Silveira, \& Marturano, 2008; Neufeld \& Maehara, 2011; Weber et al., 2006). Nenhuma diferença quanto a sexo, idade das crianças e dos pais e queixas foi encontrada na comparação do presente estudo com a implantação de demais programas de orientação de pais. Em relação às caracterizações de grupo de comparação e interventivo, feitas a partir de estatística descritiva, não foram encontradas variações, sendo a idade dos filhos, dos pais e o sexo das crianças muito semelhantes em ambos os grupos. Assim, não há indícios de diferenças na caracterização que possam justificar a desistência ou a continuação da participação no programa. Nenhum outro aspecto da caracterização dos participantes, do grupo interventivo e do de comparação trouxe informações que pudessem auxiliar na compreensão da dificuldade de adesão dos pais, principal desafio desse estudo. Embora os 25 participantes que receberam a intervenção tenham apresentado boa adesão, com poucas faltas, após iniciado o programa, foi extremamente desafiador formar e iniciar os grupos.

Ocorreu perda de participantes, que demonstraram interesse inicial no convite para participação, no agendamento do pré-teste, quanto no início da intervenção. Foram observadas e várias perdas antes do início da intervenção, que contou com menos de um terço da população convidada inicialmente. Deve-se ressaltar também que três grupos não se formaram, apesar de os modos de convite, contato com os participantes e estrutura do programa ter sido mantida. Os pais mostravam-se interessados no contato telefônico e presencial inicial, no entanto, não compareciam aos encontros e não justificavam suas faltas, assim, ao invés de dois grupos por semestre em cada instituição, apenas um se formou.

O problema de adesão não parece ser específico ao programa PROPAIS II, sendo descrito em outros estudos com a modalidade de orientação de pais em grupos (Bolsoni-Silva \& Marturano, 2010; Lambertucci \& Carvalho, 2008.), sobretudo ao enfocar a promoção de saúde. Ainda sobre essa questão, Bolsoni-Silva et al.(2008) e Bolsoni-Silva, Silveira \& Ribeiro, (2008) sugeriram programas mais compactos na busca do aumento de adesão, o que não se concretizou mesmo com o uso de um programa de apenas seis sessões.

Além de um conteúdo mais compacto, alguns recursos são apontados na literatura nacional na busca de facilitar a formação dos grupos e prevenir desistência. Entre elas: divulgação em diversas mídias anunciando a realização da intervenção: rádio, cartazes, palestras acerca do tema à comunidade na qual a intervenção será realizada (Bolsoni-Silva, 
Salina-Brandão, Versuti-Stoque \& Rosin, Pinola, 2008). E, para manutenção da participação, número reduzido de sessões, encontros individuais antes do início da intervenção, sessões individuais com os pais que sinalizarem maiores dificuldades no acompanhamento das sessões, possibilidade de contato telefônico ou eletrônico com os terapeutas antes das sessões e disponibilização de lanches no decorrer das intervenções (Marinho, 2005).

A não ser pela divulgação em diversas mídias, já que a intervenção do PROPAIS II foi oferecida apenas aos pais das duas instituições participantes, todos os outros recursos foram incorporados às sessões. Apesar disso a adesão não foi assegurada de modo satisfatório.

$\mathrm{Na}$ literatura internacional, parece haver menores dificuldades com adesão, sendo muitos dos programas de treinamentos de pais citados, serviços pagos. No entanto, alguns autores apontam resistência de participação de algumas famílias, necessitando do uso de recursos como role-plays do cotidiano, na tentativa de diminuir a mesma (Patterson, 2005), além de materiais de áudio e vídeo e treinamento múltiplo envolvendo pais, crianças e escola, na busca de uma maior efetividade na mudança comportamental infantil (Webster-Stratton \& Hammond,1997; Kumpfer, Molgaard, \& Spoth, 1996), indicando que a preocupação com a manutenção de participantes deve ser parte constituinte do planejamento da intervenção em orientação de pais.

\subsection{Qualidade na interação familiar e práticas educativas}

Voltando-se para os resultados referentes à interação familiar e às práticas educativas dos participantes, os resultados do programa mostraram-se, em grande parte, significativos após as seis sessões interventivas para os participantes. Os escores obtidos indicaram elevadas médias nas subescalas positivas já no pré-teste, que aumentaram ainda mais no pós-teste. Com as subescalas negativas, as médias iniciaram pequenas e, semelhantemente, diminuíram ainda mais no pós-teste, com diferenças estatisticamente identificáveis em ambas.

Como ainda não é possível mensurar classificações (clínicas e normais) por meio do instrumento de medida utilizado, a caracterização da população do estudo quanto às interações familiares torna-se restrita. No entanto ao se analisar os escores dos pais no préteste verificou-se escores não muito rebaixados nem elevados, o que pode indicar que os pais não pareciam enfrentar muitas dificuldades acerca de manter uma interação positiva com seus filhos e evitar uma educação coercitiva mesmo antes da intervenção, ou ao menos, saber o que deveriam fazer corretamente, melhorando ainda mais após a intervenção. 
Os baixos escores negativos e elevados escores nas variáveis positivas da EQIF no momento da pré testagem podem indicar que os fatores de vulnerabilidade social do bairro não prejudicavam muito a interação familiar. No entanto, nas falas dos participantes foram identificadas diversas dificuldades como: elevado uso de castigos, poucos reforçadores relacionais, escassa identificação de atividades prazerosas que poderiam ser feitas com as crianças, rigidez excessiva e uso restrito de elogios e incentivos antes do início do grupo, sinalizando a existência de problemas e justificando a intervenção.

É importante ressaltar que os participantes desse estudo não buscaram a intervenção devido a queixas clínicas, sendo uma amostra heterogênea quanto ao nível de habilidades sociais educativas parentais, práticas educativas e características de interação familiar. Assim, por se tratar de uma amostra comunitária, é usual que os escores iniciais à intervenção estivessem razoáveis ou bons. Processo semelhante foi observado no estudo de Bolsoni-Silva, Salina-Brandão, Versuti-Stoque e Rosin-Pinola, (2008) ao avaliar as práticas educativas parentais anteriormente à intervenção. Os resultados obtidos pelas autoras mostraram aumento dos escores após aplicação do programa, sinalizando que tal como na qualidade de interação familiar, pais que não apresentavam escores ruins iniciais puderam se beneficiar com a intervenção, melhorando suas práticas educativas e interação com seus filhos ou a percepção que fazem delas.

Bolsoni-Silva (2003), também verificou em seu estudo, que pais de crianças sem queixas clínicas relatavam maiores habilidades educativas em comparação a pais de crianças com clara demanda para atendimento. Sendo assim, é possível que as pessoas que aceitaram participar de uma intervenção preventiva e de promoção de saúde, já apresentassem maior repertório de práticas educativas adequadas.

A redução dos escores negativos e o aumento dos positivos observados após a aplicação do PROPAIS II sugerem que ocorreram mudanças importantes na maneira em que os participantes avaliam suas práticas educativas e interação com os filhos. Essas são reforçadas pelas falas dos mesmos, descritas na categoria "Mudanças", apresentadas nos Resultados. Isso indica que a intervenção pode ter auxiliando em diversos aspectos das interações educativas dos pais com seus filhos como: expressão de afeto, elogios e engajamento em atividades conjuntas prazerosas com as crianças, evidenciada por um aumento na subescala "Relacionamento Afetivo", ilustrada em muitos dos relatos compartilhados pelos membros.

A afetividade foi tema destacado no programa, sendo relembrado por todos os participantes na avaliação final como importante para implementar mudanças nas maneiras de 
educar seus filhos. Frequentemente os pais comentavam que não sabiam ao certo o que elogiar, nem o que era obrigação da criança e voltavam-se mais aos aspectos que careciam de melhora, deixando de lado os elogios e incentivos àquilo que as crianças desempenhavam bem ou se esforçavam.

Incentivar o uso de práticas educativas positivas, como elogio, tem sido temática de destaque na orientação de pais. De acordo com Motta, Falcone, Clark e Manhães (2006) a atribuição de qualidades positivas é uma boa estratégia para promover o autoconceito e a empatia na criança, contribuindo para seu relacionamento com os outros. Visando um bom desenvolvimento infantil, menor incidência de problemas comportamentais e emocionais, os pais devem garantir afeto e atenção e evitar formas agressivas de estabelecer limite, pois o uso de práticas coercitivas pode gerar ansiedade, afetar a autoestima negativamente e aumentar a agressividade infantil pela repetição de modelos agressivos dos pais (Bolsoni-Silva, et al., 2008a).

Um estudo realizado por Bolsoni-Silva e Marturano (2007) identificou outro aspecto importante relacionado à expressão de atenção e elogio a comportamentos adequados das crianças: a melhor discriminação e reconhecimento dos comportamentos habilidosos dos filhos. Ao conduzirem uma comparação entre pais de crianças socialmente habilidosas e pais de crianças com problemas de comportamento, perceberam que ambos os grupos são capazes de elogiar seus filhos e reforçar bons comportamentos, aprendendo essa habilidade, no entanto sugerem que mães com filhos que apresentam problemas de comportamento têm mais dificuldades em identificar o que merece ser elogiado ou reforçado, sendo necessário não só ensinar como incentivar a elogiar, mas auxiliar os pais a discriminarem comportamentos que devem ser merecedores de consequências positivas.

O programa PROPAIS II enfatizou, em todas as sessões, a observação dos pais de seus comportamentos, emoções e pensamentos durante as interações com seus filhos, bem como as relações entre os comportamentos infantis e seus próprios. Para o treino de elogio e reforço de bons comportamentos, todos os exemplos de situações partiram de exemplos dos próprios pais, guiados pelos terapeutas. Isso pode ter contribuído para uma melhor discriminação de momentos merecedores de elogio e atenção positiva e do aumento do uso desses recursos pelos participantes.

Um aspecto importante acerca do incentivo a elogiar, é que ele não pode ser utilizado indiscriminadamente. Ao ser oferecido de forma não contigente ao bom comportamento infantil pode perder sua efetividade e, quando é feito de maneira a não valorizar o esforço da criança, mas apenas os resultados, pode acarretar impactos negativos na motivação e no 
comportamento infantil. De acordo com a literatura de processos de aprendizagem em crianças, elogios excessivos e/ou que destacam apenas os pontos positivos das crianças, podem ser problemáticos, levando-as a evitar desafios e permanecer apenas no que já sabem que são bons. Sendo ideal que o elogio também englobe o esforço das crianças em melhorar também áreas de dificuldade (Dweck,2006). No decorrer do PROPAIS II os pais são orientados a selecionar momentos e práticas importantes de serem elogiadas, bem como outros reforços que devem ser utilizados além do elogio, como práticas de monitoria positiva.

Outras diferenças encontradas referem-se ao aumento nos escores de Envolvimento, Sentimento dos pais em relação aos filhos e Regras e Monitoria. Através de seus relatos em sessão, os pais mostraram-se mais próximos das crianças, mais pacientes ao explicar e colocar regras e com maior consciência que mudar é um processo trabalhoso, que requer consistência e persistência. Após a testagem final, no resultado da subescala Modelo e ao longo das sessões, parecem ter percebido com maior ênfase que seus próprios comportamentos são observados pelas crianças e influenciam no educar. Relataram também que se esforçaram para modificar alguns comportamentos inadequados, como falta de rotina para dormir, emprego de pequenas mentiras no cotidiano e uso de gritos e xingamentos com as pessoas ao seu redor.

A comunicação eficaz foi um tema trabalhado diretamente no programa, na póstestagem, foi observado aumento da Comunicação Positiva dos pais com seus filhos e diminuição da Comunicação Negativa, que inclui gritos, xingamentos e rotulações. O instrumento avalia apenas a percepção dos pais acerca desses tópicos, não oferecendo medidas observáveis de mudança comportamental. A melhora pode tanto indicar uma efetiva mudança quanto um ganho de percepção da importância de melhor comunicação e assertividade no educar.

A diminuição de Punição Corporal e Clima Conjugal Negativo também foi significativa após a aplicação do programa. Apesar de utilizarem instrumentos de mensuração diversos, outros programas de orientação de pais também mostraram diminuição de Punição Corporal, (Weber, et. al, 2006; Marinho, 2005). Foram poucas as falas, durante as seis sessões dos seis grupos realizados em que descreveram o uso de punição física, apesar do escore no pós-teste ter diminuído ainda mais no pós-teste, sinalizando melhora, isso pode dever-se ao contexto específico de promoção de saúde ou ainda a dificuldade dos pais em relatar práticas punitivas no início dos grupos.

São escassos os estudos que utilizam a EQIF (versão pais) como medida em orientação de pais. $\mathrm{O}$ instrumento foi elaborado inicialmente como mensuração da percepção dos filhos em relação a seus pais e não dos pais sobre suas próprias práticas educativas, sendo 
as validações da escala concluídas apenas para a versão dos filhos, que infelizmente não pode ser incorporada nesse estudo, devido à dificuldade das crianças em compreendê-la e realizar seu preenchimento, o que foi testado na experiência piloto. Assim, torna-se apenas possível comparar os resultados obtidos no PROPAIS II, com os do programa de Qualidade na Interação Familiar (PQIF), que propôs a versão pais desse instrumento. A efetividade do PQIF foi investigada a partir de avaliações qualitativas e os resultados apontaram para mudanças comportamentais dos pais na educação de seus filhos, tais como: aumento da participação e do envolvimento, maior clareza e consistência no estabelecimento de regras, aumento do uso de elogios e diminuição no uso de palmadas (Weber, et al., 2006). Ambos os programas, de mesmo objetivo, obtiveram ganhos quanto às medidas comportamentais. Várias foram as semelhanças na comparação entre os dois programas, sobretudo quanto a comportamentos envolvendo a emissão de elogios e reforços, e diminuição da punição corporal.

A principal diferença encontrada no PROPAIS II, ao se comparar com os demais programas de orientação de pais comportamentais, relaciona-se a aspectos de percepção, que está ligada diretamente ao componente cognitivo. Melhoras significativas nesse componente indica a importância de inseri-los em mais intervenções com pais, já que se encontra extremamente restrito, não aparecendo em outros programas de promoção de saúde disponíveis na literatura. Durante as sessões e ao final da avaliação, vários participantes relataram estarem mais conscientes do que sentem e pensam e da relação disso com seus comportamentos no educar. Os exemplos citados pelos participantes relacionam-se à identificação de possíveis distorções cognitivas e alcance de flexibilização de algumas crenças que estavam presentes na pré testagem e sessões iniciais: como: "ele faz para me afrontar quando eu já tô estressada", "fazer direito é obrigação de filho" e "não consigo fazer de outro jeito" e "antes quando a gente apanhava, a gente obedecia e não tinha problema".

A tomada de consciência de que pensamentos e emoções influenciam na hora de compreender o comportamento infantil e a agir parece ter sido de grande contribuição para os participantes para a melhora de algumas práticas. As destacadas em seus relatos foram: elogiar mais, estar mais envolvido, estar atento ao modelo que são para as crianças, diminuir o uso de punições físicas e agressividade, além de conseguirem aproveitar de maneira mais prazerosa o convívio com suas crianças.

Apesar de não enfatizarem os aspectos cognitivos, justamente por se ancorarem em outras abordagens teóricas, outros programas interventivos de foco semelhante ao PROPAIS II também obtiveram ganhos em relação ao aumento de percepção dos pais. O PQIF (Weber, 
et al., 2006) mostrou melhoras na percepção dos pais quanto à discriminação de estímulos, por exemplo: identificar com mais facilidade antecedentes para maus comportamentos, a percepção de que as crianças imitam seus comportamentos e que devem ser coerentes com o que ensinam e fazem e a consciência de que repetem muitas vezes o que passaram com seus pais quando eram crianças. O programa de Silva (2000), voltado para pais de crianças sem demanda clínica, apresenta, sobretudo, melhoras comportamentais dos participantes como: aumento de elogios, agradecimentos, maior assertividade ao fazer pedidos e ordens. Em relação à percepção dos pais destaca como melhoras: a aquisição de consciência dos pais das dificuldades que encontram, sobretudo no uso de punições e falas mais agressivas e na consciência do que devem fazer para mudá-lo, embora ainda não o consigam.

Nestes programas, a percepção dos pais parece ser vista como uma ampliação na habilidade de observar e discriminar elementos importantes para a modificação do comportamento de seus filhos e se adequarem melhor a eles, modificando suas práticas. No presente estudo, apesar de também enfatizar o treinamento e a observação dos comportamentos infantis, percebe-se também ganhos de autobservação, tendo os participantes relatados terem se tornado mais atentos a seus próprios estados emocionais e cognitivos. Hipotetiza-se então, que explicar o modelo cognitivo, de forma direta aos pais, evidenciando a relação entre pensamentos, emoções e comportamentos (nas situações de interação com seus filhos) auxilia que os pais se percebam melhor e compreendam que não precisam só modificar comportamentos problemáticos das crianças e próprios, mas a forma como enxergam essas situações, pois suas avaliações podem estar permeadas por sentimentos ou pensamentos distorcidos que atrapalham a assertividade.

Após seis encontros do programa, a maioria dos participantes relatou ter passado a se perceber melhor e avaliar seus sentimentos e pensamentos ao se depararem com situações desafiadoras. Parecem ter passado a fazer essa avaliação de forma mais flexível e embasada em evidências, tomando decisões após refletirem, o que se demonstrou benéfico para a interação familiar. Esta corrobora com a literatura cognitivo-comportamental, que afirma que, junto ao treino comportamental, ao se conscientizar os pais acerca de suas próprias maneiras de educar, dos papéis que assumem e dos sentimentos e interpretações que fazem do comportamento de seus filhos e de si próprios, torna-se mais fácil que escolham práticas educativas mais adequadas e eficazes (Caminha, et al., 2007; Neufeld \& Maehara, 2011).

No entanto, promover uma mudança de comportamento efetiva é um processo que pode demorar. Mais tempo ainda se leva para reestruturar pensamentos e crenças disfuncionais recorrentes, até que os novos hábitos sejam incorporados. Mais estudos 
necessitam ser feitos para que os fatores facilitadores de mudança possam ser mais bem delimitados e aproveitados em futuras intervenções para pais.

Em relação à duração do grupo, que é breve, os resultados apontaram a mudanças significativas em vários fatores da interação familiar, parecendo ser suficiente para promover modificações importantes. As falas dos pais indicam desejo de mais encontros, no entanto com pouca disponibilidade de tempo para um programa mais longo. O investimento em estudos futuros com follow-ups dos participantes desse programa e demais intervenções semelhantes será útil para verificar se essa modificação se confirma e se é duradoura.

\subsection{Comportamentos infantis.}

Para avaliar modificações no comportamento das crianças após a aplicação do PROPAIS II, ou mesmo mudanças nas percepções que os pais tinham em relação ao comportamento de seus filhos, foi utilizado o instrumento CBCL. Os relatos dos participantes acerca dos problemas comportamentais iniciais e as mudanças observadas também foram úteis para identificar possíveis efeitos do programa nessa variável.

Os escores do pré-teste do CBCL mostraram diversos problemas de comportamento nas crianças, classificados na faixa mais grave do instrumento. As falas dos participantes nas sessões iniciais do grupo também destacaram muitas dificuldades com as crianças, sobretudo com comportamentos externalizantes, entre eles: desobediência, birra, comportamentos disruptivos, problemas de conduta, desorganização e descumprimento de regras e limites. Quanto a problemas internalizantes foi ressaltado: pouca autonomia da criança, elevados níveis de preocupação e insegurança.

No momento da pré-testagem, foi superior o número de crianças problemas classificados na faixa clínica do que na faixa e normalidade, para todos os aspectos mensurados: competência social total, problemas internalizantes e externalizantes. Por se tratar de uma amostra não clínica a caracterização dos comportamentos dos filhos mostrou-se preocupante, já que os escores assemelham-se aos categorizados para amostras clínicas de crianças em atendimento psicológico (Borsa, Segabinazi, Stenert, Yates, \& Bandeira, 2013).

Esses indicativos reiteram a necessidade de intervenções que identifiquem e auxiliem as crianças com problemas de comportamento. Seja para a prevenção de problemas futuros ou para que estes não sejam agravados até a busca de tratamento tardio. 
Após a intervenção, foram observados no grupo como um todo, reduções nos escores de problemas de comportamento e mudanças da categoria clínica para a não-clínica no pós-teste nas três variáveis: social, problemas internalizantes e externalizantes. Houve também melhora de alguns problemas de comportamento após a aplicação do programa: a categoria Problemas Externalizantes como um todo e, dentro dela os comportamentos agressivos também apresentaram redução significativa.

No PROPAIS II não há avaliação direta do comportamento infantil, sendo as mudanças detectadas pautadas na observação dos pais. Conforme destaca Marinho (2005), estudos que contam com mudanças na avaliação do comportamento infantil apresentadas pelos pais podem indicar tanto que as crianças apresentaram melhoras em comportamentos antes considerados problemas, como também que os pais passaram a perceber seus filhos de modo diferente, não sendo as duas hipóteses excludentes. A autora destaca também que, independente de qual das explicações é mais provável nos programas que utilizam-se dessa forma de mensuração, o efeito da mudança no cotidiano das famílias tende a ser positivo: seja menor ocorrência de problemas infantis ou pela flexibilização da percepção dos pais acerca dos problemas e motivações infantis. De acordo com o modelo cognitivo de Beck mudanças de percepção e interpretação viabilizam mudanças de comportamentos e sentimentos, que podem também ocorrer no campo de interações familiares.

A diminuição de problemas externalizantes observada no PROPAIS II apareceu de forma semelhante em outros programas de orientação de pais que também utilizaram o CBCL como medida comportamental. Como exemplo, o programa voltado para pais de préescolares, com duração de 14 sessões, de Bolsoni-Silva e Marturano (2010), que acusou reduções significativas de problemas externalizantes e na escala total de problemas. A intervenção de Fernandes, Luiz, Miyazaki e Marques Filho (2009) com 10 sessões de 90 minutos, para pais de crianças com transtornos psiquiátricos mostrou redução significativa para problemas internzalizantes, externalizantes e totais, com estes últimos mantendo-se clínicos mesmo após a intervenção.

Deve-se atentar ao fato desses programas voltarem-se para amostras clínicas, em que problemas de comportamento graves ocorre com maior frequência, sendo ligeiramente superiores à da amostra do PROPAIS II. O estudo de Bolsoni-Silva, et al. (2008) voltado, por sua vez, para a prevenção de problemas de comportamento, mensurou mudanças positivas de categorias, com diminuição de classificações clínicas no pós-teste, semelhante ao encontrado no do presente estudo, no entanto sem indicação de comparações estatísticas. 
Não foram detectadas mudanças nos comportamentos internalizantes das crianças após o programa, tampouco disponíveis na literatura de orientação de pais, diferenças estatísticas nessa categoria de problemas. Hipotetiza-se que os problemas de comportamento internalizantes, além de menos prevalentes na população, contam com uma difícil detecção por parte dos pais e professores, perdendo espaço para as queixas de comportamentos disruptivos dos filhos nos encontros de orientação de pais. Estudos como os de Gardner, Shaw, Dishion, Burton e Supplee (2007) e Eyberg, Nelson e Boggs (2008), apontam que o treinamento de pais é a modalidade de tratamento melhor estabelecida para tratamento de transtornos disruptivos em crianças, sendo justificável que o enfoque da maioria dos programas seja para esses problemas.

Por mais que o PROPAIS II volte-se para queixas diversas, a ênfase dos participantes em problemas externalizantes, expressos no CBCL e nos relatos, levam a maiores intervenções na busca de melhorá-los. Talvez por isso, ele e outros programas que enfocam modificação de comportamentos infantis obtenham resultados mais expressivos na redução de problemas externalizantes do que de internalizantes.

Os relatos dos participantes nas sessões finais do programa, de maneira diversa, se estenderam à melhora de problemas internalizantes, como ganho de autonomia para as crianças muito dependentes. Foi observado também que os pais compreenderam que, conforme eles mudam as crianças reagem e mudam também e, que essa mudança é gradual e decorrente de um processo de consistência e persistência. De acordo com seus relatos, a grande maioria terminou a intervenção do PROPAIS II motivada a manter-se nesse processo, na busca de melhor qualidade na interação com seus filhos.

Outro aspecto que pode ter influenciado na manutenção de diversos problemas comportamentais das crianças, detectados no pré-teste, é o tempo curto do programa. As seis sessões podem não ser suficientes para auxiliar os pais a, através da melhora de suas práticas educativas, melhorar o repertório comportamental de seus filhos. A mudança comportamental tende a ser demorada e pode não se instalar durante o breve intervalo das testagens, correspondentes a três meses.

A incorporação de follow-ups pode auxiliar a verificar se a mudança dos pais se mantém e começa a influenciar positivamente o comportamento infantil e/ou se seria necessária uma intervenção mais longa. Os próprios participantes, quando questionados na avaliação sobre a satisfação com o programa e sobre as sugestões que teriam, chamaram a atenção para a curta duração do grupo, afirmando que queriam participar de mais sessões. No entanto, reiteraram que não teriam disponibilidade de estarem presentes em mais sessões com 
intervalos semanais, desejando que estas fossem espaçadas, o que dificultaria que se mantivesse a configuração de grupo, o que se tornaria inviável nesse estudo. É necessário avaliar, se a ampliação das sessões não acarretaria em uma perda ainda mais significativa da adesão dos pais, maior desafio encontrado durante a implantação do PROPAIS II. 


\section{Considerações Finais}

A implementação do programa PROPAIS II nos seis grupos que compuseram esse estudo trouxe resultados satisfatórios, que são indicativos da efetividade do programa em diversos aspectos. Enfrentou também desafios que sugerem necessidade de maiores investigações e futuras adaptações.

Os resultados do programa mostraram melhoras significativas para os participantes, relacionadas principalmente às práticas educativas parentais e interação dos pais com seus filhos. A partir dos instrumentos de mensuração e das falas dos participantes observou-se: aumento do uso de elogio, melhora da monitoria positiva dos pais e da disposição para engajarem-se na mudança comportamental de seus filhos, melhoras na comunicação, maior consistência no estabelecimento de regras e limites e melhor expressão de sentimentos. Os participantes mostraram também, ampliação da consciência de que seus comportamentos afetam o de seus filhos e que são modelos para eles, bem como da relação entre seus pensamentos, emoções e comportamentos, como preconiza o modelo cognitivo de Beck.

Ao longo do programa, sobretudo após a psicoeducação do modelo cognitivo e treino de identificação de distorções cognitivas associadas às práticas educativas e comportamentos das crianças, os pais mostraram-se mais conscientes de como avaliavam, se sentiam e do que faziam frente a comportamentos problemáticos de seus filhos. Parecem ter se tornado também mais realistas em compreender o processo de mudança, pois inicialmente esperavam resoluções prontas e que fossem guiados quanto ao que fazer com as crianças, enquanto nas sessões finais traziam, eles próprios, soluções e entendiam que mudanças ocorrem aos poucos, com a persistência de seus esforços e com dificuldades. Apesar de o treinamento comportamental ter sido trabalhado no PROPAIS II, foi importante que percebessem que mudar é gradual, requer esforço, envolvimento, tempo e engajamento na manutenção de novas práticas educativas. Ao se reconhecerem como modelos para as crianças necessitaram rever hábitos e práticas, mudando o ambiente das crianças, para que só assim, observassem mudanças no comportamento dos filhos.

Ao se conscientizarem das interpretações que fazem do comportamento das crianças, os pais puderam tornar-se mais flexíveis, diminuindo a emissão automática de práticas educativas inadequadas, como a punição corporal. Perceberam também a necessidade de se 
acalmarem para conseguirem educar e, em alguns momentos da intervenção, mostraram-se aliviados por não precisarem saber resolver todos os problemas sozinhos.

Todos esses elementos de mudança pautados em percepção puderam ser avaliados apenas com base nos relatos dos participantes, sendo importante o desenvolvimento de instrumentos de mensuração de práticas educativas que incorporem o aspecto cognitivo e emocional dos pais. Ao aliar aspectos qualitativos, como as análises de relatos, com instrumentos de medidas, torna-se possível compreender melhor a função do componente cognitivo, que nesse estudo parece ter sido fundamental para a melhora das práticas educativas dos pais, necessitando mais investigação para que sua importância possa se confirmar.

A melhora no comportamento infantil também pode ser identificada. Esta se centrou em problemas externalizantes, sendo verificada mudança sobretudo quanto à agressividade. A maioria das queixas dos participantes ao iniciar a intervenção eram também externalizantes, levando a intervenções mais focadas a esses problemas, o que pode ter justificado que só esse tipo de problema diminuiu no pós-teste. É importante ressaltar que o estudo não contou com medidas diretas de observação do comportamento infantil, tendo apenas a avaliação dos pais através do instrumento CBCL para fazer a comparação pré e pós. Instrumentos de relato trazem limitações ao estudo, pela dificuldade em saber se a percepção dos pais é condizente com a realidade dos comportamentos infantis, sendo importante, a implementação de outros modos de avaliação do comportamento das crianças, para uma avaliação mais completa de mudança.

Outro elemento importante do PROPAIS II foi a possibilidade de maior integração e contato entre os pais, sendo que os grupos atuaram como forma de fortalecimento de vínculos para vários participantes. As falas coletadas ao longo das sessões apontaram para o pouco convívio que os pais tinham antes, entre si e com a instituição, e que, algumas vezes, achavam que suas dificuldades eram únicas. Ao trocarem experiências, aprenderam não só com as orientações dos terapeutas, mas com as vivências de cada um. Além de espaço de troca e informação, vários dos pais comentaram que levavam as informações a outros pais que não puderam participar ou que não tinham filhos nas instituições em que foi oferecido, mas que enfrentavam alguma dificuldade ao educar. A disseminação de informações do grupo, por pais que já participaram, pode ser um fator para auxiliar na adesão para intervenções futuras junto às comunidades das duas instituições.

Todos os resultados destacados foram observados após uma intervenção breve, apenas com seis encontros, indicando aspectos fortes do programa PROPAIS II e levando ganhos 
para o campo da orientação de pais, embora seja necessária uma maior investigação acerca da duração ideal do programa, já que a redução tão expressiva do número de sessões tenha ocorrido em resposta à dificuldade de adesão dos pais sem demanda clínica.

A maior dificuldade do estudo, como já mencionado, foi a adesão inicial. Obter participantes e motivá-los entre a reunião de convite e o início das sessões foi desafiador e, em muitas situações, uma tarefa falha, apesar das tentativas. A queda de participantes entre o convite e a primeira sessão interventiva foi de mais de um terço dos participantes. Depois de formados os grupos a adesão manteve-se boa, com poucas faltas, mas com uma média pequena de participantes em todos os seis grupos propostos.

Buscou-se compreender o motivo da perda de interesse dos participantes que aceitaram participar na reunião feita para o convite, no entanto, nas tentativas de contato dos terapeutas com os pais inicialmente interessados, não foi possível identificar fatores que pudessem estar interferindo na participação Embora tenham sido convidados novamente para as próximas edições de implantação do programa, não compareceram.

A dificuldade com a adesão fez com que o delineamento original de se realizar dois grupos por semestre em cada instituição tivesse que ser alterado, já que apenas os grupos da primeira metade do semestre se formaram. Continuar a busca por compreender esse fator é fundamental, apesar de não ser uma dificuldade exclusiva do programa PROPAIS, tendo sido descrita em outros programas de orientação de pais, sobretudo em promoção de saúde.

O problema da falta de adesão com pais em estudos de Promoção pode se originar por visar participantes que não estão necessariamente procurando ajuda, mesmo que se verifique demanda após a aplicação dos instrumentos de avaliação. No Brasil, parece incomum os pais frequentarem a escola e instituições dos seus filhos, além das atividades obrigatórias. Muitas vezes isso se dá por motivo de trabalho e falta de tempo, sem convívio dos pais com a instituição, o que torna complicado trazê-los para um espaço em que estão habituados a apenas levarem os filhos. Tais hipóteses talvez possam explicar a dificuldade encontrada nesse estudo e verificada em programas semelhantes.

$\mathrm{Na}$ tentativa de melhorar adesão para implantações futuras do PROPAIS II, é importante a continuidade de investimento em estratégias para manutenção da frequência dos participantes, como ligações semanais, contato direto com a instituição, disponibilidade de tirar dúvidas individuais com os pais e conteúdo focado e prática, lanche ao final dos encontros, ente outros. Mas também, é fundamental, no planejamento de cada intervenção, reconhecer a demanda dos participantes dentro de uma instituição, para que se possa propor um trabalho que abarquem suas reais necessidades, ouvir os pais, compreender suas 
dificuldades, tanto com os filhos, quanto aspectos de si próprios que possam atrapalhá-los. Para isso, cabe maior proximidade entre terapeutas, pais e instituições onde a intervenção é oferecida e atentar às características da comunidade, aspectos relevantes à identificação de lacunas entre as demandas e a intervenção a ser feita, assim como para identificar outros problemas que possam estar influenciando na desistência dos pais.

Além da dificuldade com a adesão inicial, outros aspectos foram limitadores do estudo: destaca-se que um dos instrumentos utilizado para a coleta de dados, a EQIF, não teve ainda suas propriedades psicométricas avaliadas, não permitindo comparações da amostra do estudo com a população geral. A escolha por esse instrumento reflete um desafio com o qual a pesquisa se deparou: a escassez de instrumentos mensuradores de práticas educativas e /ou interação familiar na literatura que avaliem a visão dos pais acerca de suas próprias práticas, o que levou à escolha por um mensurador apenas clínico, mas que enfocasse os aspectos necessários para o presente estudo.

A escassez de instrumentos também foi verificada quanto a mensuradores de aspectos cognitivos. Apesar do foco cognitivo do estudo, todos os instrumentos utilizados foram comportamentais, não estando disponíveis instrumentos cognitivos acerca da interação dos pais com seus filhos. Dessa forma, os relatos e falas dos pais ao longo das sessões e na avaliação final foram os únicos indicadores de possíveis mudanças cognitivas e emocionais.

Outra limitação é que, os resultados da pesquisa foram obtidos com base nos relatos dos participantes. Medidas de autorrelato estão sujeitas a vieses por diversos fatores, como a desejabilidade social e o desejo dos pais em acertar, além de mostrarem o que os pais pensam sobre as questões e, não necessariamente, o que fazem. Estudos incluindo observações podem ser úteis para complementar os resultados dessa pesquisa.

A implantação inicial do PROPAIS II, nesses seis primeiros grupos, não contou com avaliações de seguimento, para verificar se as mudanças observadas se mantinham ao longo do tempo. Estudos de follow-ups para acompanhar os efeitos da intervenção são de grande importância e podem trazer melhor compreensão da efetividade do programa. Infelizmente, eles não puderam ser incorporados nesse estudo, pela dificuldade em contatar os pais após o término da intervenção. Muitos pais perderam contato com as instituições em que os grupos foram oferecidos por terem se mudado de bairro, trocado as crianças de escola e, sobretudo, por não atualizarem os cadastros junto às mesmas, mantendo como contato números de telefone que já não lhe pertenciam. Uma tentativa de follow-up foi feita no primeiro grupo interventivo, no entanto essas dificuldades e o baixo retorno, em um grupo que já era pequeno 
inviabilizou sua realização, sendo de extrema importância que novos estudos os incorporem para verificar a manutenção e/ou modificação dos resultados obtidos.

A validade ecológica do estudo foi priorizada nessa pesquisa. Ela direcionou as escolhas metodológicas realizadas na busca de diminuir a interferência no contexto da pesquisa, para identificar inclusive, os desafios reais da implantação de um programa cognitivocomportamental de orientação de pais em promoção de saúde. Como aspecto negativo dessa escolha há a diminuição do controle das variáveis intervenientes, que possam influenciar a intervenção.

Para futuros estudos, a incorporação de follow up, de medidas de avaliação complementares ao autorrelato e o investimento em instrumentos de orientação de pais que incorporem aspectos cognitivos podem auxiliar na verificação da efetividade o PROPAIS II. Independente dessas alterações, mais aplicações do programa, alcançando a participação de maior número de pais, nas mesmas e em outras instituições é fundamental para avaliar se as mudanças obtidas no presente estudo se mantêm ou se alteram, para que possa ser aplicável e eficaz à população.

Observa-se que, apesar das limitações discutidas anteriormente, o PROPAIS II demonstrou ser efetivo na produção de mudanças positivas noscomportamentos parentais, contribuindo para a prática clínica e para expansão da pesquisa no campo da orientação de pais. Por sua curta duração e fácil adaptação a diferentes demandas familiares, torna-se de acessível para aplicação e, possibilita que seja implantando com famílias com filhos sem demandas clínicas aparentes, podendo atuar como fator de proteção.

A observação do aumento da percepção dos pais acerca dos próprios comportamentos e os das crianças, sugerem a importância do investimento na inserção de fatores cognitivos na pesquisa em orientação de pais. Os resultados observados na implantação do PROPAIS II, corroborando com a literatura recente da terapia cognitivo-comportal ,sugerem que a inclusão do modelo cognitivo em programas para pais atua como elemento complementar importante para a mudança de comportamento parental e infantil, necessitando ser incentivada em futuras intervenções. 


\section{Referências $^{3}$}

Achenbach, T. M., \& Rescorla, L. A. (2001). Manual for the ASEBA School-Age Forms \& Profiles. Burlington, University of Vermont: Research Center for Children, Youth, \& Families.

Alves, R. R. (2009). Família Patriarcal e Nuclear: Conceito, características e transformações (pp. 1-14). Trabalho apresentado no II Seminário de Pesquisa da Pós Graduação em História UFG/UCG, Goiânia, GO. Disponível em: http://pos.historia.ufg.br/up/113/o/IISPHist09_RoosembergAlves.pdf

Anselmi, L., Fleitlich-Bilyk, B., Menezes, A. M. B., Araújo, C. L., \& Rohde, L.A. (2010). Prevalence of psychiatric disorders in a Brazilian birth cohort of 11-year-olds. Soc Psychiat Epidemiol, 45,135-142. doi: 10.1007/s00127-009-0052-2

Ariès, P. (1981). História Social da Criança e da Família. Rio de Janeiro: TLC

Arruda, S. L. S. (1989). Grupo de Encontro de Mães: Vivências Clínicas do seu Funcionamento (Dissertação de Mestrado, Universidade Estadual de Campinas, Campinas). Disponível em: http://www.bibliotecadigital.unicamp.br/document/?code $=000043747$

Associação Brasileira de Empresas de Pesquisa (ABEP, 2013). Critério de Classificação Econômica Brasil. São Paulo. Disponível em: http://www.abep.org/new/criterioBrasil.aspx.

Baptista, M. N. (2009). Inventário de Percepção de Suporte Familiar (IPSF). São Paulo: Vetor.

Baptista, M. N., Cardoso, H. F., \& Gomes, J. O. (2012).Intergeracionalidade Familiar. In M. N. Baptista \& M.L.M. Teodoro (Eds.), Psicologia de família - teoria, avaliação $e$ intervenção (pp. 16-26). Porto Alegre: Artmed.

Bardin, L. (2011). Análise de conteúdo. Lisboa: Edições 70.

Barkley, R. (1997). Defiant children: a clinician's manual for assessment and parent training. Nova Iorque: The Gilford Press.

Beck, A. T. (1963). Thinking and depression. Idiosyncratic content and cognitive distortions. Arch Gen Psychiatry,9, 324-333. doi: 10.1001/archpsyc.1963.01720160014002

Beck, J. (1997). Terapia Cognitiva: Teoria e Prática. Porto Alegre: ArtMed.

Bee, H. (2003). A criança e o desenvolvimento humano. Porto Alegre: ArtMed.

\footnotetext{
${ }^{3}$ De acordo com as normas APA - 6a edição.
} 
Bem, L. A., \& Wagner, A. (2006). Reflexões sobre a construção da parentalidade e o uso de estratégias educativas em famílias debaixo nível socioeconômico. Psicologia em Estudo, 11(1), 63-71. Disponível em: http://www.scielo.br/pdf/pe/v11n1/v11n1a08.pdf

Biasoli-Alves, Z. M. M. (2005). Orientação de pais: partilhar conhecimentos sobre desenvolvimento e práticas de educação como estratégia de intervenção. Texto \& Contexto - Enfermagem, 14, 64-70. doi: 10.1590/S0104-07072005000500008

Bolsoni-Silva, A. T. (2000). Problemas de comportamento e comportamentos socialmente adequados: Sua relação com as habilidades sociais educativas dos pais (Dissertação de Mestrado). Universidade Federal de São Carlos, São Carlos.

Bolsoni-Silva, A. T. (2003). Habilidades sociais educativas, variáveis contextuais e problemas de comportamento:comparando pais e mães de pré-escolares (Tese de Doutorado). Universidade de São Paulo, Ribeirão Preto. Disponível em: http://www.teses.usp.br/teses/disponiveis/59/59137/tde-10082004-134158/pt-br.php

Bolsoni-Silva, A. T., Loureiro, S. R., \& Marturano, E. M. (2011). Roteiro de Entrevista de Habilidades Sociais Educativas Parentais (RE-HSE-P). São Paulo: Vetor.

Bolsoni-Silva, A. T., \& Marturano, E. M. (2002). Práticas educativas e problemas de comportamento: uma análise à luz das habilidades sociais. Estudos de Psicologia (Natal), 7, 227-235. doi: 10.1590/S1413-294X2002000200004

Bolsoni-Silva, A. T., \& Marturano, E. M. (2007). A qualidade da interação positiva e da consistência parental na sua relação com problemas de comportamentos de préescolares. Interamerican Journal of Psychology, 41(3), 349-358. Disponível em: http://pepsic.bvsalud.org/scielo.php?script=sci_arttext\&pid=S0034690200700030001 $\underline{0} \& \operatorname{lng}=\mathrm{pt} \& \operatorname{tln} \mathrm{g}=\mathrm{pt}$.

Bolsoni-Silva, A. T., \& Marturano, E. M. (2010). Evaluation of Group Intervention for Mothers/Caretakers of Kindergarten Children with Externalizing Behavioral Problems. Interamerican Journal of Psychology, 44(3), 411-417. Disponível em:http://revistaseletronicas.pucrs.br/ojs/index.php/revistapsico/article/viewArticle/58 13

Bolsoni-Silva, A. T., Salina-Brandão, A., Versuti-Stoque, F., \& Rosin-Pinola, A. R. (2008). Avaliação de um Programa de Intervenção de Habilidades Sociais Educativas Parentais: Um Estudo-Piloto. Psicologia Ciência e Profissão, 28(1), 18-33. doi: 10.5935/1678-9741.20110001

Bolsoni-Silva, A. T., Silveira, F. F., \& Marturano, E. M. (2008). Promovendo habilidades sociais educativas parentais na prevenção de problemas de comportamento Revista brasileira de terapia comportamental e cognitiva, 10, 125-142. Disponível em: http://pepsic.bvsalud.org/scielo.php?script=sci_arttext\&pid=S1517554520080002000 $02 \& \operatorname{lng}=$ pt\&nrm=iso $>$. ISSN 1517-5545.

Bolsoni-Silva, A. T., Silveira, F. F., \& Ribeiro, D. C. (2008). Avaliação dos efeitos de uma intervenção com mães/cuidadoras: contribuições do treinamento em habilidades 
sociais. Contextos Clínicos, 1(1), 19-27. Disponível em: http://revistas.unisinos.br/index.php/contextosclinicos/article/view/5474

Bordin, I. A. S., Rocha, M. M., Paula, C. S., Teixeira, M. C. T. V., Achenbach, T. M., Rescorla, L. A., Silvares, E. F. (2013). Child Behavior Checklist (CBCL), Youth SelfReport (YSR) and Teacher's Report Form (TRF): an overwiew of the development of the original and Brazilian versions. Cadernos de Saúde Pública, 29(1), 13-28. doi: $10.1590 /$ S0102-311X2013000100004

Bordin, I. A. S., Mari, J. J., \& Caeiro, M. F. (1995). Validação da versão brasileira do "Child Behavior Checklist" (CBCL) (Inventário de Comportamentos da Infância e Adolescência): Dados preliminares. Revista da Associação Brasileira de Psiquiatria,17 (2), 55-66.

Borsa, J. C., Segabinazi, J. D., Stenert, F., Yates, D. B., \& Bandeira, D. R. (2013). Caracterização da Clientela Infanto-Juvenil de uma Clínica-Escola de Avaliação Psicológica de uma Universidade Brasileira. Psico, 44(1), 73-81. Disponível em: http://revistaseletronicas.pucrs.br/ojs/index.php/revistapsico/article/view/10599/8850

Buss, P. M. (2000). Promoção de Saúde e Qualidade de vida. Ciência Saúde Coletiva, 5, 163 177. doi:10.1590/S1413-81232000000100014.

Caminha, M. G. (2011). Treinamento de Pais: aplicações Clínicas. In R. M. Caminha \& M. G. Caminha (Eds.), Intervenções e Treinamento de Pais na Clínica Infantil (pp. 89-120). Porto Alegre: Sinopsys.

Caminha, R. M., Bellé, A. G., \& Pelisoli, C. (2007). Caracterização e Treinamento de Fobia Específica na infância. In R. M. Caminha \& M. G. O. Caminha (Eds.), A Prática Cognitiva na Infância (pp. 121-142). São Paulo: Sinopsys.

Caminha, R. M., Soares, T., \& Kreitchmann, R. S. (2011). Intervenções Precoces: Promovendo resiliência e saúde mental. In R. M. Caminha \& M. G. Caminha (Eds.), Intervenções e Treinamento de Pais na Clínica Infantil (pp. 31-81). Porto Alegre: Sinopsys.

Caminha, R., Wainer, R., Oliveira, M. \& Piccoloto, N. (2003). Psicoterapias CognitivoComportamentais - Teoria e Prática. São Paulo: Casa do Psicólogo.

Campos, C. J. G. (2004). Método de análise de conteúdo: ferramenta para a análise de dados qualitativos no campo da saúde. Revista Brasileira de Enfermagem, 57(5), 611-614. doi: 10.1590/S0034-71672004000500019

Carvalho, M. C. O. (2000). A família contemporânea em debate. São Paulo: Educ/Cortez.

Cecconello, A. M., De Antoni, C., \& Koller, S. H. (2003). Práticas educativas, estilos parentais e abuso físico no contexto familiar. Psicologia em Estudo, 8, 45-54. doi:10.1590/S1413-73722003000300007

Chorpita, B.F.; Yim, L.M.; Donkervoet, J.C.; Arensdorf, A.; Amundsen, M.J.; McGee, C.; Serrano, A.; Yates, A.; Burns, J.A.; Morelli, P. (2002). Toward large-Scale 
implementation of empirically supported treatments for children: a review and observations by the Hawaii Empirical Basis to Services Task Force. Clin Psychol Sci Pract, 9,165-190. doi: 10.1111/j.1468-2850.2002.tb00504.x

Clark, L. (2009). SOS ajuda para pais: um guia prático para lidar com os problemas de comportamento comuns no dia-a-dia. Rio de Janeiro: Cognitiva.

Coelho, M. V., \& Murta, S. G. (2007). Treinamento de pais em grupo: um relato de experiência, Estudos de Psicologia (Campinas), 24, 333-341. doi: 10.1590/S0103166X2007000300005

Cohen J. The concepts of power analysis. (1988). In: Cohen J, (Ed.), Statistical power analysis for the behavioral sciences (pp. 1-17). Hillsdale, New Jersey: Academic Press.

Costin, J., \& Chambers, S. M. (2007). Disorder referred to a mental health clinic parent management training as a treatment for children with Oppositional Defiant Disorder referred to a mental health clinic. Clin. Child Psychol. Psychiatry, 12, 511-524. doi: $10.1177 / 1359104507080979$

Czeresnia, D. (1999). The concept of health and the difference between prevention and promotion. Cadernos de Saúde Pública, 15(4), 701-709. doi: 10.1590/S0102311X1999000400004

Del Prette, Z. A. P., \& Del Prette, A. (2005). Psicologia das habilidades sociais na infância: Teoria e Prática. Petrópolis: Vozes.

Dishion, T. J., \& Patterson, G. R. (1992). Age efects in parent training outcomes. Behavior Therapy, 23(4), 719-729. doi: 10.1016/S0005-7894(05)80231-x

Dretzke, J., Davenport, C., Frew, E., Barlow, J., Stewart-Brown, S., Bayliss, S.,... Hyde, C.(2009). The clinical eff ectiveness of different parenting programmes for children with conduct problems: A systematic review of randomized controlled trials. Child and Adolescent Psychiatry and Mental Health, 3(7), 3-10. doi: 10.1186/1753-2000-3-7.

Dweck, C. (2006). Mindset: The new psychology of success. New York: Random House.

Ellis, A. (1962). Reason and emotion in psychoterapy. New York: Stuart.

Eyberg, S. M., Nelson, M. M., \& Boggs, S. R. (2008). Evidence-based psychosocial treatments for children and adolescents with disruptive behavior. Journal of Clinical Child \& Adolescent Psychology, 37, 215-237. doi: 10.1080/15374410701820117

Feilstrecker, N., Hatzenberger, R.,\& Caminha, R. M. (2003). Técnicas CognitivoComportamentais. In: R. M. Caminha , R. Wainer, M. Oliveira \& N. M. Piccoloto (Eds.), Psicoterapias cognitivo-comportamentais: Teoria e Prática (pp.53-60). Porto Alegre: Artmed. 
Féres-Carneiro, T. (1997). Entrevista familiar estruturada: Um método de avaliação das relações familiares. Temas em Psicologia, 3, 63-94. Disponível em: http://pepsic.bvsalud.org/scielo.php?pid=S1413389X1997000300007\&script=sci_artte $\mathrm{xt}$

Féres-Carneiro, T. (2005). Entrevista familiar estruturada: Um método clínico de avaliação das relações familiares. São Paulo: Casa do Psicólogo.

Fernandes, L. F. B., Luiz, A. M. A. G., Miyazaki, M. C.O. S., \& Marques Filho, A. B. (2009). Efeitos de um programa de orientação em grupo para cuidadores de crianças com transtornos psiquiátricos Estudos de Psicologia (Campinas), 26, 147-158. doi: 10.1590/S0103-166X2009000200003

Fleitlich-Bilyk, B., \& Goodman, R. (2004). Prevalence of child and adolescent psychiatric disorders in southeast Brazil. J. Am. Acad. Child Adolesc. Psychiatry, 43, 727-734. doi: 10.1097/01.chi.0000120021.14101

Fonseca, C. (2005). Concepções de família e práticas de intervenção: uma contribuição antropológica. Saúde e Sociedade, 14(2), 50-59. Disponível em: http://www.scielo.br/pdf/sausoc/v14n2/06.pdf

Freyre, G. (1933). Casa Grande \& Senzala: formação da família brasileira sob o regime de economia patriarcal. Rio de Janeiro: Schimidt.

Friedberg, R. D. \& McClure, J. M. (2004). Trabalhando com os pais. In: R. D. Friedberg \& J. M. McClure (Eds.), A prática clínica de terapia cognitiva com crianças $e$ adolescentes (231-249). Porto Alegre: Artmed.

Gardner, F., Shaw, D., Dishion, T. J., Burton, J., \& Supplee, L. (2007). Randomized prevention trial for early conductproblems: Effects on proactive parenting and links to toddler disruptive behavior. Journal of Family Psychology, 21, 398-406. doi: doi: 10.1037/0893-3200.21.3.398

Gomide, P. I. C. (2004). Pais presentes, pais ausentes. Petrópolis: Vozes.

Gomide, P. I. C. (2006). Inventário de Estilos Parentais. Modelo teórico: Manual de Aplicação, Apuração e Interpretação. Petrópolis: Vozes.

Jacobson, N., \& Truax, P. (1991). Clinical significance: A statistical approach to defining meaningful change in psychotherapy research. Journal of Consulting and Clinical Psychology, 59, 12-19. Disponível em: http://www.personal.kent.edu/ dfresco/CRM_Readings/JCCP_Jacobson_ClinSIG.pdf

Kazdin, A. E. (2004). Evidence-based psychotherapies for children and adolescents: strategies, strenghts, and limitations. In: H. Remschmidt, M. L. Belfer \& I. Goodyer (Eds.), Facilitating pathways: care, treatment and prevention in child and adolescent mental health. Springer: Berlin. 
Kazdin, A. E. (2005). Parent management training: Treatment for oppositional, aggressive, and antisocial behavior in children and adolescents. New York: Oxford University Press.

Knapp. P. (2004). Princípios fundamentais da terapia cognitiva. In P. Knapp (Ed.), Terapia cognitivo-comportamental na prática psiquiátrica (pp. 19-41). Porto Alegre: Artmed.

Knapp, P., \& Beck, A.T. (2008). Fundamentos, modelos conceituais, aplicações e pesquisa da terapia cognitiva. Revista Brasileira de Psiquiatria, 30,54-64. Disponível em: http://www.scielo.br/scielo.php?script=sci_arttext\&pid=S151644462008000600002\&1 ng=en\&tlng=pt. 10.1590/S1516-44462008000600002.

Knapp, P. \& Rocha, D. B. (2003). Conceitualização Cognitiva: Modelo de Beck. In: R. M. Caminha, E. Wainer, M. Oliveira \& N. M. Piccoloto (Eds.), Psicoterapias cognitivocomportamentais: Teoria e Prática (pp. 39-46). São Paulo: Casa do Psicólogo.

Kendall, P. (1999). Clinical significance [Special section]. Journal of Consulting and Clinical Psychological Measurement, 56, 746-759. doi: 10.1037/0022-006X.67.3.283

Kumpfer, K. L., Molgaard, V., \& Spoth, R. (1996). The Strengthening Families Program for the prevention of delinquency and drug use. In R. D. P. R. J. McMahon (Ed.), Preventing childhood disorders, substance abuse, and delinquency (pp. 241-267). Thousand Oaks: Sage Publications, Inc.

Kumpfer, K. L., Pinyuchon M., Melo A.T., \& Whiteside H.O. (2008). Cultural adaptation process for internationaldissemination of the Strengthening Families Program. Eval. Health Prof. 31:226-239. doi:10.1177/0163278708315926.

Lambertucci, M., \& Carvalho, H. W. (2008). Avaliação da efetividade terapêutica de um programa de treinamento de pais em uma comunidade carente de Belo Horizonte. Contextos Clínicos, 1(2), 106-112. Disponível em: http://pepsic.bvsalud.org/scielo.php?pid=S198334822008000200006\&script=sci_artte $\underline{\mathrm{xt}}$

Leahy, R. L. (2006). Técnicas de terapia cognitiva: Manual do terapeuta. Porto Alegre: Artmed.

Lipp, M. N. \& Malagris, L. E. N. (2010). O treino cognitivo do controle da raiva: O passo a passo do tratamento. Rio de Janeiro: Cognitiva.

Lobo, B. O. M., Flach, K., \& Andretta, I. (2011). Treinamento de Pais na Terapia CognitivoComportamental para Crianças com Transtornos Externalizantes. Psicologia em Pesquisa. 5 (2),pp-126-134. Disponível em: http://www.ufjf.br/psicologiaempesquisa/files/2011/12/v5n2a05.pdf

Lopes, R. E.F. \& Lopes, E. J. (2008). Conhecendo-se para educar.Uberlândia: Leggis Suma.

Maehara, N. P. , Theodozio, D. R., \& Neufeld, C. B. (2010). PROPAIS-USP: Fortalecendo laços - Lembretes de apoio. Material de apoio não publicado. Laboratório de Pesquisa e Intervenção Cognitivo-Comportamental - LaPICC: Ribeirão Preto. 
Marinho, M. L. (1995). Uma proposta de atendimento em psicologia Clínica infantil: triagem permanente e grupo de apoio a pais. Anais do XIII Seminário de Extensão Universitária da Região Sul. Curitiba,PR.

Marinho, M. L. (1999). Orientação de pais em grupo: intervenção sobre diferentes queixas de comportamentos infantis (Tese de Doutorado, Universidade de São Paulo, São Paulo). Disponível em: http://bases.bireme.br/cgibin/wxislind.exe/iah/online/?IsisScript=iah/iah.xis\&src=google\&base=LILACS\&lang $=\mathrm{p} \&$ nextAction $=\operatorname{lnk} \&$ exprSearch $=234747 \&$ indexSearch $=$ ID

Marinho, M. L. (2005). Um programa estruturado para o treinamento de pais. In V. E. Caballo \& M. A. Simon (Eds.), Manual de psicologia Clínica infantil e do adolescente Transtornos específicos (pp. 417-443). São Paulo: Santos.

Marinho, M. L. \& Caballo, V. E. (2002). Comportamento antissocial infantil e seu impacto para a competência social. Psicologia, Saúde \& Doenças, 3(2), 141-147. Disponível em: http://www.scielo.oces.mctes.pt/pdf/psd/v3n2/v3n2a03.pdf

Minuchin, P. (1985). Families and individual development: Provocations from the field of family therapy. Child Development, 56, 14. Disponível em: http://cfc.uoregon.edu/classes/CPSY_642/Readings/Class\%205/P\%20Minuchin,\%201 985.pdf

Moreira, M. B., \& Medeiros, C. A. (2007). Princípios básicos de análise do comportamento. Porto Alegre: Artmed.

Motta, D. C., Falcone, E. M. O., Clark, C., \& Manhães, A. C. (2006). Práticas Educativas Positivas favorecem o desenvolvimento de empatia em crianças. Psicologia em Estudo, 11(3), 523-532. Disponível em: http://www.redalyc.org/articulo.oa?id=287122092008

Motti, T. F. G., \& Pardo, M. B. L. (2010). Intervenção com pais de crianças deficientes auditivas: elaboração e avaliação de um Programa de Orientação não presencial. Revista Brasileira de educação especial, 16, 447-462. Disponível em: http://www.scielo.br/scielo.php?script=sci_arttext\&pid=S141365382010000300009\&1 ng=en\&nrm=iso $>$. ISSN 1413-6538

Moura, S. M. S. R., \& Araújo, M. F. (2004). A Maternidade na História e a História dos Cuidados Maternos. Revista Psicologia: Ciência e Profissão 24(1), 44-55. Disponível em: http://www.scielo.br/pdf/pcp/v24n1/v24n1a06.pdf

Neufeld, C. B., \& Cavenage, C. C. (2010). Conceitualização cognitiva de caso: Uma proposta de sistematização a partir da prática Clínica e da formação de terapeutas cognitivocomportamentais. Revista Brasileira de Terapias Cognitivas, 6, p.2. Disponível em: http://www.rbtc.org.br/detalhe_artigo.asp?id=109

Neufeld, C. B., Daolio, C. C., Cassiano, M., Rossetto, C. P. F., Cavenage, C. C., (2014) PRHAVIDA: Programa Cognitivo-Comportamental de habilidades de vida para crianças e adolescentes. In: Carmem Beatriz Neufeld. (Org.). Intervenções e pesquisas 
em Terapia Cognitivo-Comportamental com indivíduos e grupos (pp. 80-115). Novo Hamburgo: Sinopsys

Neufeld, C. B., \& Maehara, N. P. (2011). Um Programa Cognitivo-Comportamental de Pais em grupo. In R. M. Caminha \& M. G. Caminha (Eds.), Intervenções e Treinamento de Pais na Clínica Infantil (pp. 149-176). Porto Alegre: Sinopsys.

Nie, N. H., Hull, C. H., \& Bent, D. H. (2003). Statistical Package for Social Sciences. São Paulo: SPSS Inc.

Olivares, J., Mendes, F. X., \& Ros, M. C. (2005). O treinamento de pais em contexto clínico e da saúde. In V. E. C. M. A. Simon (Ed.), Manual de psicologia Clínica infantil e do adolescente: Transtornos Específicos (pp. 365-385). São Paulo: Livraria Santos.

Papalia, D. E., Olds, S.W., \& Feldman, R. D. (2006). Desenvolvimento Humano. Porto Alegre: Artmed.

Pardo, M. B. L., \& Carvalho, M. S. B. (2011). Grupo de orientação de mães no contexto de uma Clínica-escola. Paidéia, 21(48), 93-100. doi: 10.1590/S0103863X2011000100011

Parsons, T., \& Bales, R. F. (1955). The american family. In T. Parsons \& R. F. Bales (Eds.), Family, socialization and the interaction process (pp.259-306). Glencoe: Free Press.

Patterson, G. R. (1974). Interventions for boys with conduct problems: Multiple settings, treatments, and criteria. Journal of Consulting and Clinical Psychology, 42, 471-481. doi: $10.1037 / \mathrm{h} 0036731$

Patterson, G. R. (2005) The next generation of PMTO Model. Behavior Therapy, vol 20 (2), 27-33. Disponível em: http://www.pmto.nl/documenten/nextgeneration.pdf

Pheula, G.; Isolan, L. (2007). Psicoterapia baseada em evidências em crianças e adolescentes. Revista Psiquiatria Clínica, v. 34, n.2, p. 74-83. doi: 10.1590/S0101-60832007000200003

Porto, P. (2005). Orientação de pais de crianças com fobia social. Revista brasileira de terapia comportamental e cognitiva, 1 , 101-110. Disponível em: http://pepsic.bvsalud.org/scielo.php?script=sci_arttext\&pid=S1808$56872005000100012 \& \operatorname{lng}=$ pt\&nrm=iso>. ISSN 1808-5687.

Prebianchi, H. B. (2011). Orientação de pais no processo de psicoterapia infantil de grupo. Psicologia em Revista, 17(1), 135-145. Disponível em: http://pepsic.bvsalud.org/scielo.php?pid=S167711682011000100010\&script=sci_artte $\underline{\mathrm{xt}}$

Romanelli, G. (1998). O relacionamento entre pais e filhos em famílias de camadas médias. Cadernos de Psicologia e Educação Paidéia, 8, 123-136. doi: 10.1590/S0103863X1998000100010 
Romanelli, G. (2000). Autoridade e Poder na Família. In M. C. B. Falcão (Ed.), A Família Contemporânea em Debate (pp.53-78). São Paulo: EDUC/Cortez.

Ruma, P. R., Burke, R. V., \& Thompson, R. W. (1996). Group parent training: Is it effective for children of all ages?. Behavior Therapy, 27(2), 159-169. doi: 10.1016/S00057894(96)80012-8

Salvador, A. P. V., \& Weber, L. N. D. (2008). A relação entre práticas educativas e estilos parentais com o desenvolvimento de crianças e adolescentes. In L. Weber (Ed.), Família e Desenvolvimento - Visões Interdisciplinares (pp. 59-79). Curitiba: Juruá Editora.

Samara, E. M. (1986). A Família Brasileira. São Paulo: Brasiliense.

Samara, E. M. (2002). O que mudou na família brasileira?: Da colônia à atualidade. Revista de Psicologia da Universidade de São Paulo, 13(2), 27-48. doi: 10.1590/S010365642002000200004

Serra-Pinheiro, M. A., Guimarães, M. M., \& Serrano, M. E. (2005). A eficácia de treinamento de pais em grupo para pacientes com transtorno desafiador de oposição: um estudo piloto. Revista de Psiquiatria Clínica, 32, 68-72. Disponível em: http://www.scielo.br/pdf/rpc/v32n2/a02v32n2.pdf

Silva, A. B., Del Prette, A., \& Del Prette, Z. A. (2000). Relacionamento pais-filhos: um programa de desenvolvimento interpessoal em grupo. Psicologia Escolar $e$ Educacional, 3(3), 203-215. Disponível em: http://www.rihs.ufscar.br/armazenagem/pdf/artigos/silva-a.-t.-b.-del-prette-a.-delprette-Z.-a.-p.-2000-.-relacionamento-pais-filhos-um-programa-de-desenvolvimentointerpessoal-em-grupo

Silvares, E. F. M. (1995). O modelo triádico no contexto de terapia comportamental com famílias. Psicologia: teoria e pesquisa, 11(3), 235-241. Disponível em: file:///C:/Users/Mar/Downloads/1606-9439-1-PB.pdf

Sousa, A. P., \& José Filho, M. (2008). A importância da parceria entre família e escola no desenvolvimento educacional Revista Iberoamericana de Educación, 44(7), 01-08. Disponível em: http://www.rieoei.org/deloslectores/1821Sousa.pdf

Stern, J. (2003). Treinamento de Pais. In J. R. White \& A. S. Freeman (Eds.), Terapia Wcognitivo-comportamental em grupo para populações e problemas específicos (pp. 381-416). São Paulo: Roca.

Teodoro, M. L.M. ( 2012). Alguns instrumentos para avaliação familiar no Brasil. In M.

N. Baptista, \& M. L. M. Teodoro (Orgs.), Psicologia de família - teoria, avaliação e intervenção (pp.240-248). Porto Alegre: Artmed.

Tharp, R. G., \& Wetzel, R. J. (1969). Behavior modification in the natural environment. New York: Academic Press. 
Weber, L. N. D. (2005). Eduque com Carinho: equilíbrio entre amor e limites. Curitiba: Juruá.

Weber, L. N. D. (2008). Interações entre Família e Desenvolvimento. In L. N. D. O. Weber (Ed.), Família e Desenvolvimento Visões Interdisciplinares (pp.9-20). Curitiba: Juruá.

Weber, L. N. D., Brandenburg, O. J., \& Salvador, A. P. V. (2006). Programa de qualidade na interação familiar (PQIF): orientação e treinamento para pais. Psico, 37(2), 139. Disponível em: http://revistaseletronicas.pucrs.br/face/ojs/index.php/revistapsico/article/viewFile/142 $\underline{8 / 1121}$

Weber, L. N. D., Prabop, P. M., Salvador, A. P. V., \& Brandenburgd, O. J. (2008). Construção e confiabilidade das escalas de qualidade na interação familiar. Psicologia Argumento, 26(52), 55-65.

Weber, L. N. D., Prado, P. M., Viezzer, A. P., \& Brandenburg, O. J. (2004). Identificação de Estilos Parentais: O Ponto de Vista dos Pais e dos Filhos Psicologia: Reflexão $e$ Crítica, 17(3), 323-331.

Weber, L. N. D., Salvador, A. P. V., \& Brandenburg, O. J. (2009). Escalas de Qualidade de Interação Familiar - EQIF. In L. N. D. Weber \& M. A. Dessen (Eds.), Pesquisando a Família: instrumentos para coleta e análise de dados (pp. 57-68). Curitiba: Juruá Editora.

Webster-Stratton, C. (1991). Annotation: strategies for helping families with conduct disordered children. Journal of Child Psychology Psychiatry, 32,1047-1062. doi: 10.1111/j.1469-7610.1991.tb00349.x

Webster-Stratton, C (2005). The incredible years: A training series for the prevention and treatment of conduct problems in young children. In E. D. Hibbs, \& R.J.Mcmahon (Eds.). Preventing childhood and adolescent disorders: $\quad$ Empiricallybases strategies for clinical practice (pp. 507-555)

Webster-Stratton, C., \& Hammond, M. (1997). Early intervention for families of preschool children with conduct problems. In M. J. e. Guralnick (Ed.), The effectiveness of early intervention.Baltimore (pp. 429-453). Baltimore: Paul H. Brookes Publishing Co.

Webster-Stratton \& Reid, M. J. (2010). The Incredible Years parents, teachers, and children training series: A multifaceted treatment approach for young children with conduct disorders. In J. R. Weisz e A. E. Kazdin (Eds.). Evidence-based psychotherapies for children and adolescents (pp. 194-210). New York, NY, US: Guilford Press

Williams, C. D. (1959). The elimination of tantrum behavior by extinction procedures. The Journal of Abnormal and Social Psychology, 59 (2), 269-273. doi: 10.1037/h0046688

Yalom, I. D., \& Leszcz, M. (2006). Psicoterapia de grupo: teoria e prática. Porto Alegre: Artmed 


\section{ANEXOS}

ANEXO A - O PROGRAMA

\begin{tabular}{|c|c|}
\hline Sessões & Principais Atividades \\
\hline $\begin{array}{c}1^{\circ} \\
\text { encontro }\end{array}$ & Pré-teste \\
\hline $1^{\mathrm{a}}$ sessão & $\begin{array}{c}\text { Apresentação da proposta do grupo e contrato, incentivo da coesão grupal } \\
\text { Discussão sobre dificuldades na educação dos filhos mais sinalizadas na } \\
\text { entrevista e explicação básica sobre habilidades sociais educativas } \\
\text { parentais }\end{array}$ \\
\hline $2^{\mathrm{a}}$ sessão & $\begin{array}{l}\text { Retomada das dificuldades, noções do desenvolvimento infantil e } \\
\text { comunicação eficaz. } \\
\text { Práticas positivas no educar: importância e dificuldades. }\end{array}$ \\
\hline $3^{a}$ sessão & $\begin{array}{l}\text { Educar: concepções acerca do papel de pai (ou cuidador), dificuldades e } \\
\text { satisfações. } \\
\text { Como os filhos reagem às ações dos pais. Psicoeducação sobre leis do } \\
\text { comportamento }\end{array}$ \\
\hline $4^{\mathrm{a}}$ sessão & $\begin{array}{l}\text { Psicoeducação do modelo cognitivo: como lidar com emoções no educar. } \\
\text { Habilidades sociais envolvidas no estabelecimento de regras e limites. }\end{array}$ \\
\hline $5^{\mathrm{a}}$ sessão & $\begin{array}{l}\text { Psicoeducação de distorções cognitivas com foco na prática. } \\
\text { Prática de resolução de problemas do cotidiano no educar }\end{array}$ \\
\hline $6^{\mathrm{a}}$ sessão & $\begin{array}{l}\text { Manejo de emoções situações difíceis e técnicas de relaxamento } \\
\text { Avaliação final do grupo e encerramento }\end{array}$ \\
\hline $\begin{array}{c}7^{\circ} \\
\text { encontro }\end{array}$ & Pós-teste \\
\hline
\end{tabular}




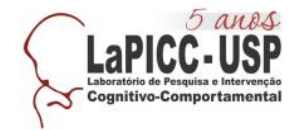




\section{ANEXO B - MATERIAL DE APOIO: ASPECTOS DO DESENVOLVIMENTO INFANTIL}

\section{$\underline{0-18 \text { meses }}$}

- O bebê é totalmente dependente de terceiros (geralmente, dos pais) para quaisquer coisas como locomoção, alimentação ou higiene.

- Aprende atos básicos de locomoção como sentar, engatinhar, andar.

- Crescimento acelerado; nascem os primeiros fios de cabelo e os primeiros dentes.

- Pronúncia das primeiras palavras.

- Período caracterizado pelo egocentrismo, pois o bebê não compreende que faz parte de uma sociedade, e o mundo para ele gira em torno de si mesmo.

\section{$\underline{18 \text { meses- } 3 \text { anos }}$}

- Desenvolvimento gradual da fala e da linguagem. Aos três anos de idade, já pode formar algumas frases completas e corretas gramaticalmente.

- Passa a compreender melhor o mundo à sua volta, e aprende que precisa seguir regras.

- Ainda bastante egocêntrica - comumente vendo outras pessoas mais como objetos do que pessoas, não sabendo que estas possuem sentimentos próprios.

- Muitas vezes prefere brincar sozinha a brincar com outras crianças da mesma faixa etária.

- No final desta faixa etária, geralmente já sabe diferenciar pessoas do sexo masculino e pessoas do sexo feminino, e também já começa a ter suas próprias preferências, como roupas e entretenimentos.

- Pode ser capaz de se vestir sem a ajuda de terceiros, e de antecipar acontecimentos.

\section{$\underline{3-5 \text { anos }}$}

- Desenvolvimento de aspectos básicos de responsabilidade e de independência, preparando a criança para o próximo estágio da infância e os anos iniciais de escola.

- São muito ativas e constantemente exploram o mundo a sua volta. Aprendem que na sociedade existem coisas que eles podem ou não fazer.

- Passam a compreender que suas ações podem afetar as pessoas a sua volta e que estas possuem sentimentos.

- Os pais da criança são os principais modelos de comportamento nessa faixa etária, mas também ocorre identificação com outras pessoas.

- Reconhecimento dos estereótipos dados a ambos os sexos pela sociedade (exemplos: menino brinca com bola, menina brinca com boneca). 
- Período escolar;

- Embora pais continuem sendo importantes, o grupo de amigos é mais influente do que antes.

- Até sete anos a criança pensa de maneira rígida: as regras não podem ser desrespeitadas e qualquer infração merece punição. Depois dessa idade, a criança fica mais flexível.

- Dos sete aos 12 anos, as crianças são mais proficientes em tarefas que exigem raciocínio lógico. Entretanto, esse raciocínio limita-se grandemente ao aqui e agora.

- Internalizam a vergonha e o orgulho e são mais capazes de compreender e de controlar emoções negativas. A empatia e o comportamento em direção ao outro aumentam.

- A agressividade normalmente diminui. A agressão relacional (isolamento e manipulação de pessoas frágeis) torna-se mais comum do que a explícita (agressões físicas), especialmente entre as meninas.

\section{$11 / 12-20$ anos}

- Passam uma quantidade de tempo cada vez maior com os amigos, mas os relacionamentos com os pais continuam sendo próximos e influentes.

- O conflito entre os pais tende a ser mais frequente durante a adolescência inicial e mais intenso na metade da adolescência. A criação baseada no diálogo está associada com os resultados mais positivos.

- Os relacionamentos com os irmãos tendem a se tornar mais igualitários e mais distantes.

- O grupo de pares pode ter influências tanto positivas como negativas. Os jovens que são rejeitados pelos amigos tendem a ter mais problemas de adaptação.

- As amizades, especialmente entre as moças, tornam-se mais íntimas e solidárias na adolescência.

- Apresentam raciocínio hipotético-dedutivo: podem pensar em termos de possibilidades, lidar flexivelmente com problemas e testar hipóteses. O desenvolvimento cerebral imaturo de adolescentes pode permitir que as emoções interfiram no pensamento racional.

- Os padrões imaturos de pensamento característicos da adolescência incluem encontrar defeitos em figuras de autoridade, a tendência a discutir, a indecisão, suposição de singularidade ("sou o único desse jeito") e de invulnerabilidade ("nada pode me atingir"). 


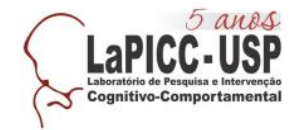




\title{
ANEXO C - DOCUMENTO DE APROVAÇÃO DO COMITÊ DE ÉTICA EM PESQUISA COM SERES HUMANOS
}

\author{
Universidade de São Paulo \\ Faculdade de Filosofia, Ciências e Letras de Ribeirão Preto \\ Comitê de Ética em Pesquisa
}

Of.CEtP/FFCLRP-USP/099/-jsI

Campus de Ribeirão Preto

Ribeirão Preto, 27 de agosto de 2012

Prezada Pesquisadora,

Comunicamos a V. Sa. que o projeto de pesquisa intitulado "INVESTIGAÇÃo DE UM PROGRAMA COGNITIVO-COMPORTAMENTAL DE ORIENTAÇÃO DE PAIS EM CONTEXTO DE PROMOÇÃO DE SAÚDE" foi reanalisado pelo Comitê de Ética em Pesquisa da FFCLRP-USP, em sua $111^{\text {a }}$ Reunião Ordinária, realizada em 23.08.12, e enquadrado na categoria: APROVADO (CAAE - 02199712.5.0000.5407).

Solicitamos que eventuais modificações ou emendas ao projeto de pesquisa sejam apresentadas ao CEP, de forma sucinta, identificando a parte do projeto a ser modificada e suas justificativas, e que, ao término do estudo, um relatório final seja entregue, via Plataforma Brasil.

Atenciosamente,

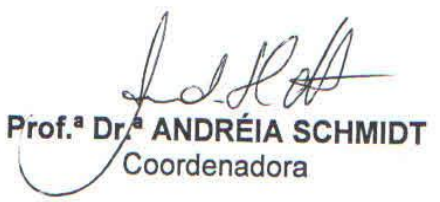

A Senhora

Marcella Cassiano

Programa de Pós-graduação em Psicologia da FFCLRP USP

Com cópia para a orientadora:

Profa. Dra. Carmem Beatriz Neulfeld

Departamento de Psicologia da FFCLRP USP

Avenida Bandeirantes, 3900 - bloco 3 - sala 16 - 14040-901 - Ribeirăo Preto - SP - Brasil

Homepage: http:///www.ffcirp. usp.br - e-mail: coetp@ffclrp.usp.br 


\section{ANEXO D \\ TERMO DE CONSENTIMENTO INFORMADO, LIVRE E ESCLARECIDO.}

Prezado pai/responsável,

Você está sendo convidado a participar de um projeto de pesquisa-ação com objetivo de investigar e avaliar os resultados de um Programa de Orientação de pais na Abordagem CognitivoComportamental para pais de crianças em idade escolar. Esse Programa é voltado para os pais de crianças que frequentam a instituição e que tenham interesse em participar das atividades propostas. $\mathrm{O}$ principal objetivo da pesquisa é propor um Programa de Orientação de pais visando auxiliar e esclarecer dificuldades e dúvidas que os pais possam apresentar na educação de seus filhos, apoiandoos mediante troca de experiências entre o grupo de participantes e orientação dos dois estagiários terapeutas em psicologia e um estagiário de psicologia observador, que coordenarão o trabalho.

Esse Programa faz parte de atividades de ensino, pesquisa e extensão, no intuito de formar profissionais qualificados para a intervenção psicológica na abordagem Cognitivo-Comportamental. Assim, os atendimentos visam, além de promover uma intervenção psicológica de orientação de pais, auxiliar na produção de conhecimentos científicos da área, sempre em concordância com as normas e critérios de Ética estipuladas pela resolução 196/96, do Conselho Nacional de Saúde sobre Pesquisa com Seres Humanos.

Todas as informações prestadas por você neste estudo são estritamente confidenciais. Os questionários de pesquisa serão identificados com um código, e não com o seu nome ou o de seu (a) filho (a). Apenas os membros do grupo de pesquisa terão conhecimento dos dados. Qualquer publicação utilizando os dados obtidos não incluirá nomes ou informações que possam os identificar.

A sua participação é voluntária e a pesquisa não prevê possibilidades de danos ou riscos a você ou ao seu (a) filho (a). No entanto, se qualquer temática da entrevista, dos instrumentos ou da intervenção lhe trouxer algum incômodo ou emoção desconfortável, toda a equipe de psicólogos e estagiários de psicologia estará à disposição para auxiliá-lo da melhor forma possível. Nenhum dos procedimentos utilizados oferece risco à sua dignidade ou de seu (a) filho (a).

Caso não deseje participar sinta-se à vontade para não assinar este termo. Além disso, você poderá retirar seu consentimento em qualquer etapa do trabalho, não havendo qualquer prejuízo às crianças ou a você caso deseje fazê-lo. Qualquer dúvida que tiver ou esclarecimento que necessitar sobre a pesquisa poderá ser fornecido em qualquer etapa do estudo pela pesquisadora Marcella Cassiano (CRP 06/102802), por email: m.marcellacassiano@gmail.com ou telefone (16)93346325. A professora Dra. Carmem Beatriz Neufeld, coordenadora de todo o estudo também está disponível para informações pelo telefone (16) 36023724 ou via email cbneufeld@ @ffclrp.usp.br.

O Programa de Orientação de pais se constituirá de seis sessões de intervenção, em grupo, que acontecerão uma vez por semana, as segundas-feiras das 19:00 às 19:30 horas. Será realizado também um encontro anterior ao início da intervenção para aplicação dos instrumentos necessários para avaliação do Programa e, focando sua interação com seu (a) filho(a) e a percepção sobre alguns de seus sentimentos e comportamentos. Após o término do grupo será realizado um encontro final, no qual os instrumentos serão aplicados novamente. No total serão realizados oito encontros, incluindo a aplicação dos instrumentos e as sessões interventivas. O áudio das sessões de intervenção será gravado para fins didáticos, auxiliando as atividades de supervisão e acompanhamento dos terapeutas para aprimorar constantemente a atuação dos terapeutas.

Não estão previstos nenhum tipo de despesa pela participação na pesquisa, bem como não haverá pagamento por sua participação, ou demais benefícios materiais. Entretanto, esperamos que este estudo possa contribuir para a saúde familiar e o desenvolvimento infantil, trazendo informações importantes sobre qualidade de interação familiar e formas de se aprimorar as habilidades educativas dos pais, que poderão trazer benefícios futuros a você, a seu filho, com a possibilidade de que no futuro possa beneficiar a outros pais e crianças que receberem a intervenção.

$\mathrm{O}$ atendimento será conduzido por estagiários de psicologia de quarto e quinto ano e observado por uma estagiária cursando o terceiro ano de psicologia, sob supervisão das psicólogas Marcella Cassiano (CRP 06/102802) e Jaqueline Pereira Dias (CRP 06/112649) e coordenação da 
Profa. Dra. Carmem Beatriz Neufeld (CRP 06/93723), docente do Departamento de Psicologia da Faculdade de Filosofia, Ciências e Letras de Ribeirão Preto da Universidade de São Paulo.

Para seu conhecimento, serão listados os instrumentos de coleta de dados a serem aplicados em você caso aceite participar dessa pesquisa. Child Behavior Checlikst (traduzido para o português), sobre comportamentos de seu (a) filho(a) e a Escala de Qualidade de Interação Familiar (EQIF) sobre relacionamentos familiares. Será aplicado também um Questionário Socioeconômico (Critério Brasil)

A aplicação, correção e armazenamento dos testes psicológicos e dos áudios das sessões será conduzida pela psicóloga Marcella Cassiano (CRP 06/102802), mestranda da Universidade de São Paulo e pelos estagiários acima mencionados, todos sob orientação da $\operatorname{Prof}^{\mathrm{a}} \operatorname{Dr}^{\mathrm{a}}$ Carmem Beatriz Neufeld (CRP 06/93723).

Atenciosamente,

Marcella Cassiano (CRP 06/102802)

Representante dos Acadêmicos

Prof. Dra. Carmem Beatriz Neufeld

Professora Orientadora (CRP 06/93723)

Autorização para Realização da Pesquisa

$\mathrm{Eu}$,

(nome legível), declaro que fui informado dos objetivos e procedimentos do trabalho acima de maneira clara e detalhada, e declaro que participarei voluntariamente desta pesquisa. Além disso, autorizo a participação de meu filho (a), no mesmo, bem como o armazenamento dos nossos

dados em um banco de dados desde que garantido o sigilo dos mesmos. Declaro que possuo cópia do Termo de Consentimento Informado, Livre e Esclarecido que ora aceito. Sei que a qualquer momento posso revogar este Aceite, sem a necessidade de prestar qualquer informação adicional. 


\title{
ANEXO E \\ TERMO DE CONSENTIMENTO INFORMADO, LIVRE E ESCLARECIDO PARA INSERÇÃO DOS DADOS DA PESQUISA EM BANCO
}

\author{
Prezado pai/responsável,
}

Você está sendo convidado a participar de um projeto de pesquisa-ação com objetivo de investigar e avaliar os resultados de um Programa de Orientação de pais na Abordagem CognitivoComportamental para pais de crianças em idade escolar. Esse Programa é voltado para os pais de crianças que frequentam a instituição e que tenham interesse em participar das atividades propostas. $\mathrm{O}$ principal objetivo da pesquisa é propor um Programa de Orientação de pais visando auxiliar e esclarecer dificuldades e dúvidas que os pais possam apresentar na educação de seus filhos, apoiandoos mediante troca de experiências entre o grupo de participantes e orientação dos dois estagiários terapeutas em psicologia e um estagiário de psicologia observador, que coordenarão o trabalho.

Antes e depois da intervenção em grupo, que terá duração de seis sessões, com uma hora cada em frequência semanal, serão aplicados alguns instrumentos em você, caso você autorize. Os instrumentos de coleta de dados a serem aplicados em você caso aceite participar dessa pesquisa são: O questionário Child Behavior Checlikst (traduzido para o português), sobre comportamentos de seu (a) filho(a); a Escala de Qualidade de Interação Familiar (EQIF) sobre relações familiares e um Questionário Socioeconômico, o Critério de Classificação Econômica Brasil (CCEB). .

A aplicação, correção e armazenamento dos testes psicológicos será conduzida pela psicóloga Marcella Cassiano (CRP 06/102802), mestranda da Universidade de São Paulo, sob orientação da Prof $^{a}$ Dr $^{a}$ Carmem Beatriz Neufeld (CRP 06/93723). Os dados da presente pesquisa serão armazenados em um banco digitalizado, nele podem ser incorporados dados futuros outras pesquisas em Orientação de pais e Promoção de Saúde do Laboratório de Pesquisa e Intervenção CognitivoComportamental (LaPICC) e ninguém além das psicólogas acima citadas terá acesso a eles, assegurando sempre o sigilo das informações prestadas. Pedimos sua autorização para armazenar seus dados nesse banco.

Pedimos sua autorização para armazenar seus dados nesse banco. Asseguramos que todas as informações prestadas por você que serão armazenadas no banco, após sua autorização, são estritamente confidenciais. Os questionários de pesquisa serão identificados com um código, e não com o seu nome ou o de seu(a) filho(a). Apenas os membros do grupo de pesquisa terão conhecimento dos dados. Qualquer publicação utilizando os dados obtidos não incluirá nomes ou informações que possam os identificar.

Caso não deseje autorizar armazenamento de seus dados no Banco de Dados da Pesquisa, você poderá participar da intervenção, caso deseje, sem nenhum prejuízo a você ou ao seu (a) filho(a). Sendo essa autorização independente da sua participação no grupo interventivo.

Além disso, você poderá retirar seu consentimento em qualquer etapa do trabalho, não havendo qualquer prejuízo a você ou seu filho caso deseje fazê-lo. Qualquer dúvida que tiver ou esclarecimento que necessitar sobre a pesquisa poderá ser fornecido em qualquer etapa do estudo pela pesquisadora Marcella Cassiano (CRP 06/102802), por email: m.marcellacassiano@gmail.com ou telefone (16) 93346325. A professora Dra. Carmem Beatriz Neufeld, coordenadora de todo o estudo também está disponível para informações pelo telefone (16) 36023724 ou via email cbneufeld@ffclrp.usp.br.

Atenciosamente,

Marcella Cassiano (CRP 06/102802)

Representante dos Acadêmicos

Prof. Dra. Carmem Beatriz Neufeld

Professora Orientadora (CRP 06/93723) 
Autorização para Armazenamento dos Dados da Pesquisa em Banco de Dados:

Eu, (nome legível), declaro que fui informado dos objetivos e procedimentos do trabalho. Autorizo o armazenamento de meus dados e de meu filho (a), , em um banco de dados desde que garantido o sigilo dos mesmos. Declaro que possuo cópia do Termo de Consentimento Informado, Livre e Esclarecido que ora aceito. Sei que a qualquer momento posso revogar este Aceite, sem a necessidade de prestar qualquer informação adicional. 


\section{ANEXO F \\ QUADRO DE IDENTIFICAÇAÇÃO COM OS NOMES FICTÍCIOS DOS PARTICIPANTES}

\begin{tabular}{|c|c|c|l|}
\hline Grupo & Instituição & Participantes & Nomes \\
\hline 1 & 1 & 5 & Clarice, Elaine, Renata, Thaís e Vivian \\
\hline 2 & 1 & 5 & Edite, Elisa, Marcos, Marina e Solange \\
\hline 3 & 1 & 5 & Aline, Anita, Maria, Pedro*e Nair* \\
\hline 4 & 2 & 5 & Carla, Esther, Fernanda, Mariana e Sílvia \\
\hline 5 & 1 & 2 & Érica e Diane \\
\hline 6 & 2 & 4 & Zélia, Sara, Vera e Eliana \\
\hline
\end{tabular}

* Pedro e Nair, participantes do grupo 4, eram casados. Apenas o pai preencheu os protocolos de testagem sobre a filha do casal, por ter participado de todas as sessões e a mãe, de apenas quatro. 
ANEXO G - FICHA DE IDENTIFICAÇÃ̃ DOS PARTICIPANTES

FICHA DE IDENTIFICAÇÃO

Nome do Responsável:

Idade:

Quantos filhos você possui? (De quantas crianças você cuida?):

Idade de cada um dos filhos:

Principal dificuldade encontrada na educação dos filhos: 
ANEXO H- FOLHA DE REGISTRO

Folha de Registro Semanal do Programa PROPAIS II

Terapeuta:

Co-terapeuta:

Observador:

Grupo: $\mathbf{n}^{\circ}$ e semestre $24-1^{\circ}$ semestre de 2013

\begin{tabular}{|l|l|}
\hline Sessão & $\mathbf{N}$ \\
\hline Data: & \\
\hline $\mathbf{N}^{\circ}$ de presentes & \\
\hline $\mathbf{N}^{\mathbf{0}}$ de faltas & \\
\hline
\end{tabular}

Nome dos participantes presentes:

Descrição da sessão: (Falas dos participantes e orientação dos terapeutas na sessão): 
Observações: (Nessa sessão devem ser inseridas quaisquer questões a serem destacadas como algum tipo de atraso, algum comportamento de algum participante que merece ser pontuado, observações sobre o funcionamento do grupo, o encaminhamento em relação aos faltantes etc.) 